\title{
Expedition 317 summary $^{1}$
}

\author{
Expedition 317 Scientists $^{2}$
}

\section{Chapter contents}

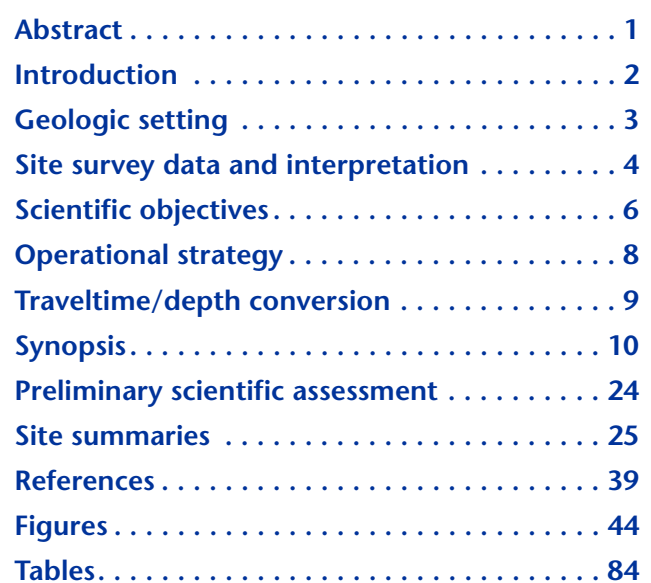

${ }^{1}$ Expedition 317 Scientists, 2011. Expedition 317 summary. In Fulthorpe, C.S., Hoyanagi, K., Blum, P., and the Expedition 317 Scientists, Proc. IODP, 317: Tokyo (Integrated Ocean Drilling Program Management International, Inc.). doi:10.2204/iodp.proc.317.101.2011

'Expedition 317 Scientists' addresses.

\section{Abstract}

Integrated Ocean Drilling Program (IODP) Expedition 317 was devoted to understanding the relative importance of global sea level (eustasy) versus local tectonic and sedimentary processes in controlling continental margin sedimentary cycles. The expedition recovered sediments from the Eocene to recent period, with a particular focus on the sequence stratigraphy of the late Miocene to recent, when global sea level change was dominated by glacioeustasy. Drilling in the Canterbury Basin, on the eastern margin of the South Island of New Zealand, takes advantage of high rates of Neogene sediment supply, which preserves a high-frequency (0.1-0.5 m.y.) record of depositional cyclicity. Because of its proximity to an uplifting mountain chain (the Southern Alps) and strong ocean currents, the Canterbury Basin provides an opportunity to study the complex interactions between processes responsible for the preserved sequence stratigraphic record. Currents have locally built large, elongate sediment drifts within the prograding Neogene section. These elongate drifts were not drilled during Expedition 317, but currents are inferred to have strongly influenced deposition across the basin, including locations lacking prominent mounded drifts.

Upper Miocene to recent sedimentary sequences were cored in a transect of three sites on the continental shelf (landward to basinward, Sites U1353, U1354, and U1351) and one on the continental slope (Site U1352). The transect provides a stratigraphic record of depositional cycles across the shallow-water environment most directly affected by relative sea level change. Lithologic boundaries provisionally correlative with seismic sequence boundaries were identified in cores from each site, providing insight into the origins of seismically resolvable sequences. This record will be used to estimate the timing and amplitude of global sea level change and to document the sedimentary processes that operate during sequence formation. Sites U1353 and U1354 provide significant double-cored, high-recovery sections through the Holocene, allowing for high-resolution study of recent glacial cycles in a continental shelf setting.

Continental slope Site U1352 represents a complete section from modern slope terrigenous sediment to hard Eocene limestone, with all the associated lithologic, biostratigraphic, physical, geochemical, and microbiological transitions. This site also provides a record of ocean circulation and fronts during the last $\sim 35$ m.y. 
The early Oligocene ( $30 \mathrm{Ma})$ Marshall Paraconformity was the deepest drilling target of Expedition 317 and was hypothesized to represent intensified current erosion or nondeposition associated with the initiation of thermohaline circulation following the separation of Australia and Antarctica.

Expedition 317 set a number of scientific ocean drilling records: (1) deepest hole drilled in a single expedition and second deepest hole in the history of scientific ocean drilling (Hole U1352C, $1927 \mathrm{~m}$ ); (2) deepest hole and second deepest hole drilled by the $\mathrm{R} / \mathrm{V}$ JOIDES Resolution on a continental shelf (Hole U1351B, 1030 m; Hole U1353B, 614 m); (3) shallowest water depth for a site drilled by the JOIDES Resolution for scientific purposes (Site U1353, $84.7 \mathrm{~m}$ water depth); and (4) deepest sample taken during scientific ocean drilling for microbiological studies (Site U1352, $1925 \mathrm{~m}$ ).

Expedition 317 supplements previous drilling of sedimentary successions for sequence stratigraphic and sea level objectives, particularly drilling on the New Jersey margin (Ocean Drilling Program [ODP] Legs 150, 150X, 174A, and 174AX and IODP Expedition 313 ) and in the Bahamas (ODP Leg 166), but includes an expanded Pliocene section. Completion of at least one transect across a geographically and tectonically distinct siliciclastic margin was the necessary next step in deciphering continental margin stratigraphy. Expedition 317 also complements ODP Leg 181, the focus of which was drift development in more distal parts of the Eastern New Zealand Oceanic Sedimentary System (ENZOSS).

\section{Introduction}

Defining the relative importance of global sea level (eustasy) versus local tectonic, sedimentary, and oceanographic processes in controlling continental margin depositional cyclicity is a fundamental problem in sedimentary geology. A better understanding of how these processes interact to form preserved stratigraphy would greatly enhance our ability to read the record, covering many tens of millions of years, of Earth history contained within the thick sedimentary deposits beneath the world's continental shelves. This problem was addressed during Integrated Ocean Drilling Program (IODP) Expedition 317 by drilling the Canterbury Basin on the eastern margin of the South Island of New Zealand (Figs. F1, F2, F3).

The geologic record provides an opportunity to quantify the timing, rate, amplitude, mechanisms/ controls, and effects (stratigraphic response) of eustatic change, which in turn provides a baseline for predicting future relative sea level changes and as- sessing anthropogenic influences. However, eustatic effects are complexly intertwined with processes of basin subsidence and sediment supply (e.g., Cloetingh et al., 1985; Karner, 1986; Posamentier et al., 1988; Christie-Blick et al., 1990; Reynolds et al., 1991; Christie-Blick and Driscoll, 1995; Kominz et al., 1998; Kominz and Pekar, 2001). Controversy arises from the application of the sequence stratigraphic model (Mitchum et al., 1977; Van Wagoner et al., 1988; Posamentier et al., 1988; Posamentier and Vail, 1988; Vail et al., 1991) to sea level studies. Sequence stratigraphy has highlighted the cyclical nature of the continental margin stratigraphic record and led to the theory of eustatic sequence control as well as the resultant eustatic cycle chart (Haq et al., 1987). This global sea level model remains contentious (e.g., Cloetingh et al., 1985; Carter, 1985; Karner, 1986; Christie-Blick et al., 1990; ChristieBlick, 1991; Carter et al., 1991; Karner et al., 1993; Christie-Blick and Driscoll, 1995; Dewey and Pitman, 1998; Miall and Miall, 2001).

High rates of Neogene sediment supply preserved a high-frequency (0.1-0.5 m.y.) seismically resolvable record of depositional cyclicity in the offshore Canterbury Basin (Fulthorpe and Carter, 1989; Browne and Naish, 2003; Lu and Fulthorpe, 2004). Exploration wells indicate the presence of middle Miocene to recent sedimentary sequences that are generally correlative in age with those drilled on the New Jersey margin by the Ocean Drilling Program (ODP). However, the Canterbury Basin differs in ways that allow for expanded study of the complex processes of sequence formation in line with the global approach to sea level change advocated by previous planning groups:

1. The stratigraphy records the early development of the Antarctic circumpolar circulation and related southern oceanographic fronts. Currents strongly influenced deposition, modifying sequence architecture and locally leading to the deposition of large sediment drifts that aggraded to upper-slope depths within the prograding Neogene section.

2. Rifting is younger (Cretaceous) than the New Jersey margin (Jurassic), and from the earliest Miocene copious terrigenous sediment was supplied from a rapidly uplifting nearby mountain range (the Southern Alps). Regional tectonic and geologic histories have been intensively studied, allowing evaluation of the influence of sediment supply on sequence formation and of the tectonic evolution of the Alpine Fault plate boundary.

The Canterbury Basin is part of the Eastern New Zealand Oceanic Sedimentary System (ENZOSS) (Carter 
et al., 1996). The distal (up to $4460 \mathrm{~m}$ water depth) component of ENZOSS was targeted by ODP Leg 181, which focused on drift development in the southwest Pacific gateway, principally under the influence of the evolving Antarctic Circumpolar Current and the Deep Western Boundary Current (Shipboard Scientific Party, 1999a). Expedition 317 complements Leg 181 drilling by focusing on the landward part of ENZOSS.

\section{Geologic setting \\ Regional geology}

The eastern margin of the South Island of New Zealand is part of a continental fragment, the New Zealand Plateau, that rifted from Antarctica beginning at $\sim 80 \mathrm{Ma}$ (Anomaly 33). Rifting between the New Zealand Plateau and Antarctica-Australia was active along a mid-ocean-ridge system passing through the southern Tasman Sea and Pacific basins until $\sim 55 \mathrm{Ma}$ (Anomaly 24). Linking of the Indian Ocean and Pacific spreading centers truncated the spreading ridge in the southern Tasman Sea in the late Eocene. Spreading rates on the Indian and Pacific segments of this now-continuous Southern Ocean ridge system resulted in the formation of the modern boundary between the Australian and Pacific plates composed of the Macquarie Ridge, the Alpine Fault, and the Tonga-Kermadec subduction zone (Molnar et al., 1975).

The Canterbury Basin lies at the landward edge of the rifted continental fragment and underlies the present-day onshore Canterbury Plains and offshore continental shelf (Field and Browne, 1989). Banks and Otago peninsulas (Fig. F2) are mid-late Miocene volcanic centers. Basin sediments thin toward these features as well as westward, where they onlap basement rocks onshore that are involved in uplift and faulting linked to the latest Miocene (8-5 Ma) initiation of the current period of mountain building along the Southern Alps (Adams, 1979; Tippett and Kamp, 1993a; Batt et al., 2000).

The plate tectonic history of the New Zealand Plateau is recorded in the stratigraphy of the South Island. The postrift Cretaceous to recent sedimentary history of the Canterbury Basin is composed of a first-order (80 m.y.), tectonically controlled transgressive-regressive cycle (Carter and Norris, 1976; Field and Browne, 1989). The basin formed part of a simple passive margin from the Late Cretaceous to some time in the late Eocene, when convergence between the Australasian and Pacific plates began to influence the region, eventually leading to the formation of the Alpine Fault at 23 Ma (Wellman, 1971; King, 2000). The Cretaceous-Tertiary sedimentary section can be divided into three principal intervals, the Onekakara, Kekenodon, and Otakou groups (Carter, 1988), during which contrasting large-scale sedimentary processes operated (Fig. F4).

\section{Cretaceous-Paleogene transgression and Oligocene highstand}

The postrift transgressive phase (Onekakara Group) produced ramplike seismic geometries and terminated during the late Eocene, when flooding of the landmass was at a maximum (Fleming, 1962). Reduced terrigenous influx during the postrift phase of subsidence and transgression resulted in the deposition of regionally widespread siliceous or calcareous biopelagites (Amuri Limestone) as young as early Oligocene ( $33 \mathrm{Ma})$. This sequence is interrupted by a current-induced unconformity, the Marshall Paraconformity (Carter and Landis, 1972), which occurs at the base of the mid-late Oligocene cross-bedded glauconitic sand (Concord Formation) and calcarenite limestone (Weka Pass Formation) that compose the Kekenodon Group (Fig. F4) (Carter, 1985, 1988). Exploration wells and Leg 181 drilling (ODP Sites 1123 and 1124; Carter et al., 2004c) revealed that the paraconformity as well as the probable equivalents of the Amuri Limestone and Weka Pass Formation exist offshore (Wilding and Sweetman, 1971; Milne et al., 1975; Hawkes and Mound, 1984; Wilson, 1985). The paraconformity, the deepest drilling target of Expedition 317, has also been recognized at drill sites throughout the region east of the Tasmanian gateway and is hypothesized to represent the initiation of thermohaline circulation (Deep Western Boundary Current) and shallower circulation upon the opening of the seaway between Antarctica and Australia ( 33.7 Ma) prior to the opening of the Drake Passage (Carter et al., 2004c). New Zealand lay directly in the path of this developing current system. The paraconformity has also been studied in onshore outcrops (e.g., Findlay, 1980; Field and Browne, 1989; Carter and Landis, 1972; Lever, 2007) and dated by biostratigraphy and more recently by strontium isotopes at a South Canterbury outcrop. The hiatus has been dated at 32.4-29 Ma (Fulthorpe et al., 1996). Its deepwater representation may have started to form 1-2 m.y. earlier (Carter et al., 2004c).

\section{Miocene-recent regression}

Regression commenced in the late Oligocene or early Miocene in response to an increase in sediment supply provided by the initiation of Alpine Fault movement (Carter and Norris, 1976; Kamp, 1987). The Alpine Fault formed as a dextral strike-slip zone, with $500 \mathrm{~km}$ displacement since the earliest Miocene ( 23 Ma) (Kamp, 1987). In eastern South Island, this re- 
sulted in the deposition of a widespread shelf siltstone (Bluecliffs Formation), starting in the latest Oligocene or earliest Miocene. At abyssal depths in the path of the Deep Western Boundary Current, fine-grained terrigenous-carbonate rhythms at 41 k.y. Milankovitch frequency commenced at almost the same time ( 24-23 Ma) (Carter et al., 2004c). This early uplift is not recognized by fission track dating (e.g., Batt et al., 2000) and is distinct from the later pulse of uplift that culminated in the presentday Southern Alps. Uplift of the Southern Alps accelerated at $\sim 8-5$ Ma (Tippett and Kamp, 1993a; Batt et al., 2000) or 10-8 Ma (Carter and Norris, 1976; Norris et al., 1978; Adams, 1979; Tippett and Kamp, 1993b), indicating an increased component of convergence along the fault. Transpression led to an increase in the rate of sediment supply to the offshore Canterbury Basin (Lu et al., 2005). As in New Jersey, this sediment influx was deposited as prograding clinoforms (Otakou Group; Fig. F4). Currents continued to influence deposition. At present, the core of the northward-flowing Southland Current, inboard of the Southland Front (part of the Subtropical Front [STF]), is near the $\sim 300 \mathrm{~m}$ isobath (Chiswell, 1996). In deeper water of at least $900 \mathrm{~m}$, a local gyre of the Antarctic Circumpolar Current circulates clockwise within the head of Bounty Trough parallel to the Southland Current (Fig. F2) (Morris et al., 2001). Large sediment drifts within the prograding section (Fig. F4) show that similar currents existed throughout much of the Neogene (Fulthorpe and Carter, 1991; Lu et al., 2003; Carter et al., 2004c). Carter (2007) has applied the term "Canterbury Drifts" to describe the ensemble of shelf-slope sediments that have been deposited under the influence of northflowing currents since the latest Oligocene.

\section{Subsidence history}

Backstripping suggests an increase in tectonic subsidence in the central part of the offshore basin starting at $\sim 8$ Ma (Figs. F5, F6) (Browne and Field, 1988) or perhaps as early as $20 \mathrm{Ma}$ (M. Kominz, pers. comm., 2009). This increased subsidence may be a response to increasing convergence at the Alpine Fault (Lu et al., 2005). The transect approach of Expedition 317 will help us to model the presumed two-dimensional subsidence effect of Alpine Fault convergence, allowing us to remove the tectonic portion of subsidence and leave the eustatic signal. Figures F5 and F6 also show evidence for uplift at $\sim 50-35 \mathrm{Ma}$, which could reflect the late Eocene reorganization of plate boundaries.

\section{Site survey data and interpretation \\ Data acquisition}

A large amount of multichannel seismic (MCS) data, collected in 1982 for a petroleum exploration consortium (BP Shell Todd), is available for the offshore Canterbury Basin (CB-82 profiles; e.g., Fulthorpe and Carter, 1989). Although the data cover an extensive area, they exhibit relatively low vertical resolution $(20 \mathrm{~m})$. Therefore, this survey was augmented in 2000 by two-dimensional high-resolution MCS profiles (R/V Maurice Ewing Cruise EW00-01; Figs. F3, F7, F8, F9). The survey grid lies approximately midway between the Banks and Otago peninsulas on the present-day middle to outer shelf and slope, above the late Miocene to recent depocenter and over the area where the largest sediment drifts developed (Fig. F3). The seismic source consisted of two generatorinjector (GI) air guns $\left(45 / 45 \mathrm{in}^{3}\right)$, and the streamer was deployed with $12.5 \mathrm{~m}$ groups in 96- and 120channel configurations. A total of 57 profiles ( 3750 line-km) were collected, covering $\sim 4840 \mathrm{~km}^{2}$. Line spacings are $0.7-3.0 \mathrm{~km}$ in the dip direction and 2.0 $5.5 \mathrm{~km}$ in the strike direction. The penetration of 1.7-2.0 s below seafloor is sufficient to image the entire Oligocene to recent section. Data processing used Focus software, and the data were loaded into the GeoQuest interpretation system. High resolution was achieved by using reliable high-frequency sources (maximum frequency $=500 \mathrm{~Hz}$ ), small sample intervals $(1 \mathrm{~ms})$, and high fold (48-60). Vertical resolution $(\sim 5 \mathrm{~m}$ for two-way traveltime $<1 \mathrm{~s})$ is as much as $4-5$ times better than that of existing commercial MCS data (Fig. F10). However, seafloor and peg leg multiples are pronounced beneath the shelf. In order to deal with this problem, prestack deconvolution and FK-filtering were applied to critical sections, yielding some improvements in quality.

Commercial low-resolution MCS grid data were used to extend interpretations beyond the EW00-01 grid. CB-82 data were particularly useful for tying to exploration wells, determining sediment drift distribution, and locating clinoform rollovers, onlap, and canyons associated with the oldest sequences. The grid consists of 81 profiles, representing 6000 line$\mathrm{km}$ (Fig. F3). The record length is $5 \mathrm{~s}$, and the sample rate is $4 \mathrm{~ms}$. Digital copies of all stacked profiles were loaded into the GeoQuest system. Paper copies of migrated profiles were also available, and 20 of the digital profiles were migrated as part of this project. 


\section{Seismic stratigraphy}

The EW00-01 MCS data were interpreted to provide a high-frequency sequence stratigraphic framework for the offshore Canterbury Basin (e.g., Fig. F7). Nineteen regional seismic sequence boundaries (U1U19) were identified in the middle Miocene to recent shelf-slope sediment prism of the offshore Canterbury Basin (Lu and Fulthorpe, 2004). Three larger seismic units were defined based on seismic architecture and facies (Fig. F7):

1. U1-U4 mostly lack distinct clinoform breaks within the seismic coverage.

2. U5-U8 feature rounded breaks; internal reflection geometries are predominantly sigmoid, and paleoshelves are smooth and defined by onlap and truncation.

3. U9-U19 are downlapped on paleoshelves and truncate underlying reflections near paleoshelf edges; internal reflection geometries are oblique, and $\mathrm{U}$ - and $\mathrm{V}$-shaped channels incising paleoshelves indicate exposure during sea level lowstands.

The predrilling ages of U3-U10 were initially based on ties to the Clipper exploration well (Hawkes and Mound, 1984), and the ages of U11-U19 were based on ties to ODP Site 1119 (Fig. F11) (Shipboard Scientific Party, 1999b; R.M. Carter, pers. comm., 2002). The Endeavour (Wilding and Sweetman, 1971) and Resolution (Milne et al., 1975) exploration wells were tied to the EW00-01 survey using the commercial CB-82 MCS profiles to calibrate the lowermost seismic sequence boundaries (U1-U3) (Fig. F7). Late Pliocene to recent age seismic sequence boundaries U11-U19 were considered the most reliable because they were derived from the continuously cored Site 1119. The Site 1119 section is virtually complete; only one downlap unconformity (U18 at $\sim 87$ meters below seafloor [mbsf], representing the Stage 7/8 boundary at $\sim 252-277$ k.y.) has a significant hiatus ( 25 k.y.). U19 ( 48 mbsf) corresponds to the Stage $5 / 6$ boundary $(\sim 113 \mathrm{ka})$ at Site 1119 , and the age of the deepest sediment recovered at Site 1119 is $~ 3.9$ Ma (Carter et al., 2004a). The predrilling ages of lower Pliocene and Miocene unconformities were less well constrained.

Expedition 317 drilling indicates that predrilling age estimates for most seismic sequence boundaries agree reasonably well with drilling results (see "Synopsis"). Only U7 was off by a significant margin (4.3-5.3 Ma versus the predicted $9 \mathrm{Ma}$; see "Synopsis"). A tentative correlation with oxygen isotopic records based on predrilling age estimates suggests a eustatic origin for the seismic sequence boundaries. When cycles of comparable frequency are compared, the number of seismic sequences is similar to that of coeval cycles on the Miocene to recent $\delta^{18} \mathrm{O}$ values of seawater $\left(\delta^{18} \mathrm{O}_{\mathrm{sw}}\right)$ record of Billups and Schrag (2002) (Fig. F11). However, local processes also exerted fundamental control on sequence architecture. Alongstrike currents strongly influenced sequence development, and large sediment drifts dominate parts of the Neogene section.

\section{Sediment drifts and paleoflow}

The presence of long-lived drifts beneath the modern shelf confirms that currents swept the New Zealand plateau as early as $15 \mathrm{Ma}$ (Fig. F12) (Lu and Fulthorpe, 2004), and onshore outcrops of Kekenodon Group Greensand and limestone indicate that the current influence extends back to the late Oligocene (Ward and Lewis, 1975). The STF, Subantarctic Front (SAF), and associated currents may have existed close to their present positions relative to New Zealand by the middle or latest Miocene (Carter et al., 2004c; Nelson and Cooke, 2001). The STF is represented by the Southland Front along the eastern South Island (Fig. F2). The $\delta^{13} \mathrm{C}$ record at Site 1119 is interpreted as reflecting glacial-interglacial alternations of subtropical and subantarctic water caused by movement of the STF across the site over at least the last two glacial-interglacial cycles (Carter et al., 2004a, 2004b). Falling sea level deflected the front basinward during glacial periods, with the counterintuitive result that the site experienced a warmer watermass during glacials; intervals of interbedded sand and mud mark the passage of the front basinward and landward across the site (Carter et al., 2004b). Sand beds occurring near the peak of glaciation are interpreted as representing the proximity of the STF and SAF, which may have coalesced near the site, intensifying current strength (Carter et al., 2004b).

Currents formed at least 11 large, elongate drifts within the lower Miocene to recent section (e.g., Fig. F12) (Lu et al., 2003; note that timing is based on predrilling ages). These drifts were initiated near the slope toe and aggraded to near-shelf water depths. Drift deposits are as thick as $1000 \mathrm{~m}$ and have mounded morphologies with channel-like moats along their landward flanks. Internal geometries define two elongate drift end-members: simple and complex. Early (middle Miocene) simple drifts are small and are concentrated in the southern part of the survey area (Figs. F3, F7). Drift thickness and longevity increased as the shelf aggraded, increasing accommodation space, while the locus of drift development migrated northeastward. Late (late Miocene to recent) simple drifts are therefore larger and occur in the northeastern part of the survey area (Figs. F3, F8). Late simple drifts are divided into three parts (base, core, and crest) based on seismic facies. These 
facies form in response to progressive confinement of current flow within the moat. Complex drifts (multicrested and multistage; Fig. F3) may form as current pathways migrate in response to sea level change, modulated by paleoslope inclination, and as a result of fluctuations in the rate of sediment supply.

Current erosion in drift moats forms diachronous unconformities that cut across sequence boundaries. Several sequence boundaries pass through some of the larger drifts, indicating that they existed throughout several cycles of relative sea level change (Figs. F7, F8). Drift deposition controls sequence thickness distributions: sequences are thickest at drift mounds and thinnest within moats. In addition, currents focus deposition on the slope, reducing the rate of basinward movement of the shelf edge but increasing that of the slope toe. As a result, slope inclination is minimized (cf. Figs. F8, F9). The cessation of drift development and the replacement of along-strike processes with downslope processes result in increased rates of shelf-edge progradation and slope steepening as the accommodation space over the expanded slope is filled. Slope platforms can form above extinct drifts, reducing accommodation and locally accelerating shelf-edge progradation and slope steepening. The termination of large, elongate drift development ( 3.25 Ma at Site 1119; Carter et al., 2004a) may have resulted from the initiation of late Pliocene to Pleistocene high-amplitude sea level change, which enhanced downslope processes by exposing the shelf edge. In spite of the demonstrable presence of a current, seismic evidence for current activity is lacking and coeval strata are clinoformal along strike from some large, elongate drifts (Fig. F9). Therefore, elongate drift formation is the product of multiple controls, including current intensity, seafloor morphology, and sediment input.

\section{Scientific objectives \\ Primary objective}

\section{Date clinoform seismic sequence boundaries and sample-associated facies to estimate eustatic amplitudes}

Facies, paleoenvironments, and depositional processes associated with the sequence stratigraphic model on prograding continental margins, where sequences are best resolved seismically, have yet to be adequately constrained by scientific ocean drilling. The prediction of sediment distribution within sequences is highly model dependent (e.g., systems tract models of Posamentier et al., 1988; Vail et al., 1991). These models offer great potential for under- standing oil and gas resources and for ground water/ pollution remediation issues. However, the fundamental assumptions and predictive capabilities of these models can only be tested by drilling on shallow continental shelves. Drilling contrasts upper Miocene-lower Pliocene sequences with smooth, onlapped paleoshelves and rounded breakpoints (seismic sequence boundary U10 and below) to upper Pliocene-Pleistocene sequences with eroded and incised, downlapped paleoshelves and more pronounced breakpoints (above U10) (Fig. F7). This tests the hypothesis that paleoshelves below U10 were not subaerially exposed at sequence boundaries, whereas those above $\sim \mathrm{U} 10$ were exposed.

\section{Secondary objectives}

\section{Drill the Marshall Paraconformity in the offshore basin}

Drilling the Marshall Paraconformity offshore provides information on its regional distribution, age, and origin (Figs. F4, F8, F9). The paraconformity has been dated at its onshore type section using strontium isotopes and represents a $\sim 3.4$ m.y. hiatus (32.4-29 Ma; Fulthorpe et al., 1996). It is therefore correlative with the postulated early Oligocene eustatic lowstand (Haq et al., 1987). However, a eustatic lowstand is unlikely to have been the direct cause of the paraconformity because correlative features have been inferred to form in water as deep as 4000-5000 $\mathrm{m}$ throughout the southwest Pacific (Carter, 1985; Carter et al., 2004c). The limited paleoenvironmental data available suggest that, even at current onshore locations, the Marshall Paraconformity could not have been widely subaerially exposed, although such exposure may have occurred at localized highs (Lewis, 1992).

Instead, the paraconformity probably records intensified current erosion or nondeposition at all water depths, which was accompanied by the development of a current system following the opening of the seaway south of Tasmania (Carter, 1985; Fulthorpe et al., 1996; Carter et al., 2004c). Seismic interpretation supports a current-related origin by indicating that the paraconformity forms the base of the interval of sediment drift deposition. Indeed, immediately post-Marshall Paraconformity, sedimentation involved sediment drift deposition in shallow (Ward and Lewis, 1975), intermediate (Fulthorpe and Carter, 1991; Lu et al., 2003), and deep (Shipboard Scientific Party, 1999a; Carter et al., 2004c) water settings. Leg 181 drilling indicates that the paraconformity developed in deep (bathyal) water 1-2 m.y. earlier than in shallow water (McGonigal and Di Ste- 
fano, 2002). Dating this paraconformity in the offshore Canterbury Basin at Site U1352 tested this hypothesis.

\section{Constrain the erosion history of the Southern Alps}

The late Oligocene to early Miocene increase in sediment supply to the offshore basin apparently predates the modern transpressional uplift of the Southern Alps, whose main pulse began at $\sim 8-5 \mathrm{Ma}$ (Tippett and Kamp, 1993a; Batt et al., 2000) or 10-8 Ma (Carter and Norris, 1976; Norris et al., 1978; Adams, 1979; Tippett and Kamp, 1993b). Such onshore results correlate with increases in subsidence rate and sediment supply in the offshore basin (Figs. F5, F6, F11) but may underestimate earlier, but significant, convergence and uplift (Walcott, 1998). The offshore sedimentary prism is the only record of erosion that precedes the current uplift phase, constituting a record of age, volume, and facies of erosion products from the Oligocene to recent.

Sediment volumes within mapped seismic sequences provide a measure of onshore paleoerosion rates. Calculating such volumes involves integration of both industry and EW00-01 MCS data because the commercial data have broader aerial coverage (Fig. F3). Sequence volumes were used to calculate sedimentation rates (Fig. F11) (Lu et al., 2005). Limited available age control precluded estimation of meaningful sedimentation rates for individual sequences because such rates are strongly influenced by sequence duration. Therefore, sedimentation rates averaged over groups of sequences are presented instead. The resulting rates correlate well with estimates of the perpendicular component (convergence) of relative plate motion at the Alpine Fault: both increase during the last 5-8 m.y. (Fig. F11). In contrast, high sedimentation rates from 14.5 to 11.5 Ma occurred during a period of low convergence rate at the fault ( $\mathrm{Lu}$ et al., 2005). However, these high rates correlate with similar peaks in sedimentation rates elsewhere, such as off New Jersey and West Africa (Steckler et al., 1999; Lavier et al., 2000, 2001), and occur during a period of falling global sea level (Fig. F11). They are probably, therefore, a response to global climatic trends. Drilling results will be used to verify the ages of the progradational units, which will be integrated with sediment volume results to provide an enhanced, sequence-by-sequence record of sedimentation rates for correlation with tectonic and climatic events. Provenance studies will further add to our understanding of the early history of the plate boundary. Mineralogical and isotopic analyses of sand grains, along with Ar-Ar dating of those grains, will allow the matching of outcrop ages and source areas to sequences offshore. Ideally, we would have liked to calibrate sequences through the entire Neogene section, but penetration of the entire section at shelf water depths is technically difficult and time consuming. As a compromise, Expedition 317 sites targeted seismic sequence boundaries down to U4 ( 12.4 Ma), although U5 was the oldest sequence boundary actually penetrated.

\section{Determine sediment drift depositional histories and paleoceanographic record}

Elongate drifts parallel to the shelf edge are unusual features in such an inboard continental margin setting, and their facies are largely unknown. They were probably deposited adjacent to a current flowing northward along the prograding clinoform slope; progradation in parts of the basin occurred by the accretion of successive sediment drifts (Fulthorpe and Carter, 1991; Lu et al., 2003). The drifts can encompass several seismic sequences, and the erosional unconformities in moats are diachronous (Figs. F7, F8, F12) (Lu et al., 2003). Drift formation is not, therefore, linked directly to individual sea level cycles. Data from Site 1119 (Leg 181) confirmed the drift origin of these features; interglacial silty sand and glacial silty clay cycles were recognized in current-deposited sediments (Shipboard Scientific Party, 1999b). However, Site 1119 penetrated only to 494.8 mbsf in $3.9 \mathrm{Ma}$ sediments, which is insufficient to sample more than the upper few meters of the underlying large, elongate drift (D10 of Lu et al., 2003; Carter et al., 2004a). The earlier history of the frontal systems is therefore poorly constrained. In addition, the climatic record of Site 1119 correlates well with that from the Vostok ice core (Carter et al., 2004b), and drilling deeper could provide an extended proxy for Antarctic continental air temperatures. Furthermore, D11 can be considered the type example of a late, simple, elongate drift, and it displays all of the component seismic facies (base, core, and crest) (Lu et al., 2003). It is estimated to be of late Miocene $(\sim 11 \mathrm{Ma})$ to Pliocene $(\sim 3.6-3.25 \mathrm{Ma})$ age (Fig. F12) (Lu and Fulthorpe, 2004; Carter et al., 2004a) and may be the longest lived sedimentary bedform on Earth. Drilling D11 would therefore be essential to determine the lithologies that make up the large volumes of sediment within the elongate drifts and recover the paleoceanographic record contained within the drift deposit.

Because of time constraints imposed in part by the 10 day transit from Townsville, Australia (which included a fuel stop in Wellington, New Zealand), drilling D11 became a secondary objective of Expedition 317. Therefore, all sites originally proposed for drilling D11 (proposed Sites CB-05A through CB-05E) became contingency sites to be drilled only if drilling 
at shallower slope and shelf sites was not possible. However, insights into sediment drift deposition and paleoceanography were expected from drilling at shelf Site U1351 (which penetrated the paleoslopes of U6 and U7) and slope Site U1352. Drift geometries become gradually less pronounced along strike toward the southwest (from proposed CB-05 sites to the drilling transect sites), and pronounced mounded drift geometries are absent beneath the slope at Site U1352 (Lu and Fulthorpe, 2004). However, the generation of mounded drifts requires specific conditions that are not well understood; a slope contour current alone is insufficient, as indicated by the fact that such drifts are not being formed under the present current regime. It is therefore possible that currents have reworked the sediments at Sites U1351 and U1352 and left a paleoceanographic record of glacial-interglacial cycles, as at Site 1119 (Carter et al., 2004c), without producing distinctive drift geometries.

\section{Operational strategy}

\section{Drilling transect strategy}

To understand the history of eustasy versus subsidence/sediment supply changes, borehole transects across passive continental margins are required (COSOD II, 1987). The long-term strategy developed by ODP-related planning groups (Watkins and Mountain, 1990; Loutit, 1992; Fulthorpe et al., 2008) involves drilling margins worldwide to evaluate global synchroneity through correlation among multiple basins and with the oxygen isotopic record and to document stratigraphic responses in diverse tectonic and depositional settings, including carbonate, siliciclastic, and mixed siliciclastic-carbonate sedimentary systems on both continental and oceanic crust. Initial investigation was to focus on the Neogene "Icehouse" period (Miller et al., 1991), for which high-resolution chronological control is available and for which glacial cycles provide a well-understood mechanism for eustatic change, calibrated by the deep-ocean oxygen isotope record. This approach has guided ODP efforts off New Jersey (Leg 150: Mountain, Miller, Blum, et al., 1994; Miller and Mountain, 1994; Leg 174A: Austin, Christie-Blick, Malone, et al., 1998; Legs 150X and 174AX: Miller, et al., 1994; Miller, Sugarman, Browning, et al., 1998) and the Bahamas (Leg 166: Eberli et al., 1997). IODP Expedition 317 represents the latest application of this global strategy.

The passive margin approach integrates seismic profiles and a drilling transect to calibrate the sequence stratigraphic model and test the global sea level model, including investigation of local controls on sequence formation. Seismic profiles provide identification of sequence boundaries, sequence architecture, seismic facies, and morphologic constraints on depositional processes and tectonism. A drilling transect is required to document (1) ages of sequence stratigraphic surfaces, including sequence-bounding unconformities (or their correlative conformities) and maximum flooding surfaces; (2) facies and lithologies composing each sequence (stratigraphic response to sea level oscillations); (3) porosity, cementation, and diagenesis; and (4) paleowater depths from benthic biofacies. Such paleowater depth estimates are essential for determination of eustatic amplitudes. Two-dimensional modeling of these data within the sequence stratigraphic framework allows estimation of eustatic amplitudes when the form of the tectonic component of subsidence is known (Kominz and Pekar, 2001).

The ideal approach involves drilling target sequences in at least two locations. First, drilling landward of clinoform rollovers or breaks, presumed to represent paleoshelf edges, provides information on facies and water depths where paleodepth indicators are most reliable. For example, ODP Leg 174A drilling recovered valuable paleoenvironmental information diagnostic of a shallow-water lagoonal environment landward of a rollover (Austin, Christie-Blick, Malone, et al., 1998). Two-dimensional backstripping will enable the use of data from inboard sites to constrain water depths at more basinward locations. Second, drilling on the slope, where pelagic microfossils are more abundant, provides sequence boundary ages. Ideally, such sites would also provide the paleoenvironment and facies of the lowstand systems tract. This is also essential for eustatic amplitude estimation in the event that sea level fell below the preceding rollover. The ideal location for both dating and lowstand facies is near the clinoform toe to minimize the hiatus at the sequence boundary (ChristieBlick et al., 1998), but locations higher on the slope are necessary to reduce drilling depths (e.g., the location of New Jersey margin Site 1072 [Leg 174A] relative to sequence boundary $\mathrm{m} 1[\mathrm{~s}]$ ) (Austin, ChristieBlick, Malone, et al., 1998). In addition, locations on the slope will provide better constrained paleowater depths than those at clinoform toes, which are likely to involve greater uncertainty (as is the case at the Clipper well). A further reason for drilling higher on the slope is that seismic correlation from clinoform toes landward to the clinoform front and paleoshelf is difficult on all margins because the section basinward of the clinoform toe is condensed and landward divergence of reflections contributes to misties. 


\section{General operations plan}

The transect approach requires drilling operations to be conducted on the modern shelf to reach sequence paleoshelves landward of their rollovers, as well as the upper paleoslopes of the oldest sequences. ODP Leg 174A drilling on the New Jersey shelf illustrated the difficulty of shelf drilling with a dynamically positioned drilling vessel (Austin, Christie-Blick, Malone, et al., 1998). The main problem was the collapse of loose sands, which trapped the drill string, although station keeping in shallow water was also occasionally difficult. The proposed drilling strategy for Expedition 317 was influenced by the Leg 174A experience, which relied heavily on rotary core barrel (RCB) drilling, particularly at shelf Site 1072. As a result, the Expedition 317 precruise operations summary presumed extended core barrel (XCB) refusal at $\sim 350$ mbsf, with RCB coring in a separate hole to total depth.

In practice, it was possible to use the $\mathrm{XCB}$ to core to $\sim 1000 \mathrm{~m}$ at shelf Site U1351 before significant difficulty was encountered. RCB drilling was therefore unnecessary at Expedition 317 shelf sites. In contrast, the greater penetration depth required at Site U1352, on the upper slope, necessitated the use of RCB coring in a separate hole.

Favorable weather conditions on arrival allowed us to follow the original drilling strategy by drilling first at shelf Site U1351 at the deepwater end $(121 \mathrm{~m})$ of the shelf transect (Fig. F7; Table T1). This provided us with experience in shelf-sediment drilling before we moved to sites in even shallower water. Although the target depth at Site U1351 was 1249 mbsf, actual penetration of $1030 \mathrm{~m}$ nevertheless exceeded expectations in view of the difficulties encountered during Leg 174A. Unless otherwise noted, all depth references in this chapter refer to the core depth below seafloor computed by conventional method A (CSF-A) depth scale (see "IODP depth scales terminology" at www.iodp.org/program-policies/). Only the two deepest seismic sequence boundaries targeted (U4 and U5) were not reached, although recovery was limited, averaging $\sim 30 \%$ and generally decreasing with depth.

The ship then moved $\sim 15 \mathrm{~km}$ to slope Site U1352, which was selected to provide good age control for sequences drilled on the shelf at Site U1351 (Fig. F3). An additional objective at this site was penetration and recovery of the Marshall Paraconformity (Fig. F9).

On completion of slope drilling, we moved back to the shelf to drill the two additional shelf Sites U1353 and U1354 (Fig. F7) to provide spatial control of fa- cies within sequences and to recover the lowermost unconformities landward of their rollovers.

\section{Traveltime/depth conversion}

Relating seismic sequence boundaries to features observed in cores is critical to any test of continental margin sequence stratigraphy. Sequence boundaries were originally assigned predicted depths based on synthetic seismograms created using sonic and density logs from Site 1119 and commercial exploration well Clipper. Ages were also assigned to the sequence boundaries using ties to Site 1119 and the exploration wells, principally Clipper (Lu and Fulthorpe, 2004).

During safety reviews by the Environmental Protection and Safety Panel (EPSP), predicted sequence boundary depths were modified using a new analysis of check shot and sonic log information from the Clipper well and Site 1119. Seismic stacking velocities were not used for traveltime/depth conversion because they were substantially higher than those derived from Site 1119 and the Clipper well, which are in general agreement. The final traveltime/depth conversion function used to estimate sequence boundary depths prior to Expedition 317 was

$$
Y=317 X^{2}+758.3 X
$$

where

$Y=$ depth below seafloor in meters and

$X=$ two-way traveltime in seconds.

Pending postcruise analysis, depths quoted for seismic sequence boundaries in this report are derived from this predicted function. A sonic log was obtained from Hole U1351B to $\sim 490 \mathrm{~m}$ wireline log depth below seafloor (WSF), but this log requires postcruise processing before it can be used to provide an alternative traveltime/depth conversion. A sonic $\log$ was also obtained from Hole U1352B to $\sim 420 \mathrm{~m}$ WSF, and a synthetic seismogram was generated to provide an alternative traveltime/depth conversion. However, the resultant velocities proved to be anomalously lower than the predicted function, which is itself evidently too slow, at least for traveltimes corresponding to the deepest penetrations. For example, if the Marshall Paraconformity correlates, as seems likely, with seismic horizon "Green," the precruise predicted function underestimates its depth by $\sim 30-35 \mathrm{~m}$.

Results from Hole U1353C may be more representative. A sonic log to $\sim 230 \mathrm{~m}$ WSF yielded an excellent synthetic seismogram match to the seismic data and estimated depths to seismic sequence boundaries 
within the logged interval (U13-U10) that were 5$10 \mathrm{~m}$ deeper than predicted precruise. This may represent an improved traveltime/depth conversion for this interval, although the difference may be within the margin of error for both sets of traveltime/depth estimates. A sonic log was also obtained from Hole U1354C to $~ 380 \mathrm{~m}$ WSF at the end of the cruise; results have not yet been assessed.

In summary, the precruise predicted function continues to be used for core-log-seismic correlations in this report. However, postcruise analysis may lead to modifications of this function based on further evaluation of Expedition 317 wireline logging and physical property data.

\section{Synopsis}

The fundamental objective of Expedition 317 was to test the concepts of sequence stratigraphy by documenting the lithologies, ages, and depositional environments within sequences in order to determine the sedimentary processes active during sequence development and to constrain the underlying controls (both global and local) responsible for those processes. This involves testing sequence stratigraphic model (e.g., Van Wagoner et al., 1988; Vail et al., 1991) predictions of facies and lithologies associated with the development of prograding, clinoformal, continental margin sequences that are well defined by seismic interpretations. It also necessitates testing the presumption that global sea level is the primary control on sequence boundary formation (Haq et al., 1987). Other goals were coring the early Oligocene Marshall Paraconformity, constraining the early uplift and erosion history of the Southern Alps, and documenting the evolution of contourite deposition on this current-influenced margin.

Nineteen middle Miocene to Pleistocene seismic sequence boundaries (U1-U19) were defined by sequence stratigraphic interpretation of EW00-01 seismic data (Lu and Fulthorpe, 2004). Expedition 317 was designed to provide ground truth for sequences above U4 ( U5 in practice) and also to core through the Marshall Paraconformity. Prior to Expedition 317, only Leg 174A (Austin, Christie-Blick, Malone, et al., 1998) and IODP Expedition 313 (Expedition 313 Scientists, 2010) had drilled on a continental shelf for sequence stratigraphic and sea level objectives. Expedition 317, therefore, provided a rare opportunity to investigate the facies, paleoenvironments, and depositional processes associated with the sequence stratigraphic model on a prograding continental margin where large-scale depositional geometries and sequence architectures are well constrained by seismic data.

\section{Core-seismic correlation}

The Canterbury Basin formed along a passive continental margin where large volumes of sediment were derived from a tectonically and climatically evolving hinterland. Seismic sequence boundaries provide a large-scale understanding of the subsurface architecture of the margin necessary for drill site selection and for placing drilling results within a broader twodimensional and three-dimensional context. U19U6 were penetrated at outer shelf Site U1351 and mid-shelf Site U1353, the most landward site. U5 may also have been reached at Site U1353. U19-U8 were cored at intermediate shelf Site U1354. The slope facies of most seismic sequence boundaries (U19-U13, U11, and U9-U6), as well as the Marshall Paraconformity, were penetrated at Slope Site U1352 with the particular goal of providing age control for sequence boundaries. The slope facies of U6-U7 were also sampled at shelf Site U1351 (Figs. F13, F14).

Upper Miocene-lower Pliocene seismic sequence boundaries ( $\sim$ U10 and below) feature smooth, onlapped paleoshelves and rounded rollovers, or clinoform breaks, with sigmoid internal reflection geometries. In contrast, middle Pliocene to Pleistocene sequence boundaries (above U10) display eroded and incised downlapped paleoshelves and more pronounced rollovers with oblique reflection geometries. This transition reflects a background of changing paleoenvironmental conditions, against which the cored sediments can be interpreted downhole.

Similarly, the character of sequences changes horizontally landward to basinward across the transect. Sequences are not represented by a single pattern of lithofacies across the shelf and onto the slope. Shelf successions are dominated by periodic facies changes that reflect fluctuating sea level, whereas deposition of slope sediments was also influenced by northtraveling Subantarctic Mode Water (SAMW), Antarctic Intermediate Water (AAIW), and their predecessor current systems (e.g., Carter and Gammon, 2004).

Correlating seismic sequence boundaries with lithologic facies and features found in the cores will be a focus of postcruise research. However, preliminary relationships can be defined at two scales.

\section{Lithologic units}

At the largest scale, the preferred boundaries between lithologic Units I and II at outer shelf Site U1351, mid-shelf Site U1354, and inboard shelf Site U1353 are lithologic boundaries that separate the overlying heterolithic facies of Unit I from more uniform facies below in Unit II (Figs. F13, F14, F15). The unit definitions for each Expedition 317 site are based on observed variations in lithology in the 
cores, particularly in the occurrence and frequency of calcareous units (generally green, shelly, and sandy). In general, Unit I is heterogeneous, containing a wide variety of facies, including interbedded terrigenous lithologies and many green marl or calcareous beds with sharp (or bioturbated) bases (Fig. F15). Conversely, Unit II is more homogeneous. On the shelf, Unit II is dominated by mud or muddy sand, with lower percentages of carbonate components and less frequent greenish calcareous beds, whereas on the slope this unit is represented by homogeneous sandy marlstone (Figs. F15, F16). However, at each site the location of the unit boundary is difficult to identify precisely because the transition between units of this type is inevitably gradational and also because of low recovery near some unit boundaries (Fig. F17). At slope Site U1352, the homogeneous sandy marlstone of Unit II changes abruptly into foraminifer-bearing nannofossil limestone of early Oligocene to late Eocene age. This hemipelagic to pelagic unit is correlative with the onshore Amuri Limestone.

The Unit I/II boundary generally conforms to the predicted depths of seismic sequence boundaries between U9 and U12 (late Pliocene) in a zone between high-amplitude seismic reflections related to clinoforms with sharp shelf-slope transitions above and clinoforms with rounded shelf-slope transitions below. The exact location is not identical at each site, in part because of the gradational nature of the transition noted above.

At Site U1353, Unit I is thought to correspond to strata between U12 and the seafloor (Fig. F13); however, a transition zone was identified between the heterolithic Unit I and the more homogeneous Unit II, reflecting the gradational evolution of the sedimentary margin. This transition zone extends between $\sim 137$ and $178 \mathrm{~m}$ or between U12 and U11 of $\mathrm{Lu}$ and Fulthorpe (2004) (Fig. F13). Heterogeneity in lithology and composition continues to $\sim 260 \mathrm{~m}$, where an abrupt change in mineralogy was observed. The uppermost transitional part of Unit II corresponds to the sequences between U9 and U12. Below $260 \mathrm{~m}$, the homogeneous muddy sediments identified as Unit II correlate to strata between U9 and U5 (Fig. F13).

At Site U1354, the heterolithic upper Subunit IA corresponds to the high-amplitude seismic reflectors between U12 and the seafloor, which correlates to the same stratigraphic package as Unit I at Site U1353. Subunit IB lithology contains regular alternations of muddy strata and extends from just above the predicted depth of U9 to U12, equivalent to the transitional zone between Units I and II identified at Sites U1353 and U1351. Unit II corresponds to the clino- formal strata below U9, with the hole terminating between U8 and U7.

At Site U1351, Unit I is defined as extending from the seafloor to $262 \mathrm{~m}$, although a transition zone was identified between $\sim 247$ and $300 \mathrm{~m}$. This unit was distinguished by the high variability in lithofacies, which, not surprisingly, corresponds to the high-amplitude reflectors between U9 (predicted depth of $312 \mathrm{~m}$ ) and the seafloor. All of Unit II lies within the broadly clinoformal succession between $\mathrm{U} 4$ and U9. The transition zone identified in the cores between Units I and II corresponds to the zone between U9 and U10, the lowermost unit of the upper high-amplitude succession and the one most similar in shape to the underlying rounded clinoforms.

For Site U1352 the boundary between Subunits IA and IB correlates to a subsequence boundary between U18 and U19 (Fig. F14), whereas the boundary between Subunits IB and IC correlates to U14, and the boundary between Units I and II correlates to a subsequence boundary at the base of the irregularly shaped high-amplitude reflectors between U13 and U11. Subunit IB corresponds to high-amplitude reflectors, and Subunit IC correlates to the irregular (possibly drift-related) reflectors below U14. In contrast to Sites U1351 and U1354, the Unit I/II boundary at Site U1352 occurs at a much higher seismic stratigraphic level (between U11 and U13), similar to the Unit I/II boundary at Site U1353. At all sites, Unit I is differentiated from Unit II by a higher degree of lithofacies heterogeneity. Subunit IIA at Site U1352 is remarkably homogeneous, although it corresponds in age and updip correlation to the basal part of Unit I at Sites U1351 and U1354.

Subunit IIA correlates with the prograding clinoforms between U8 and the base of the aforementioned erosional features between U11 and U13. The bottommost, more calcareous, part of this subunit occurs in a set of down- and onlapping reflectors directly overlying U8. Subunit IIB correlates with the more irregular, possibly channelized, reflectors between U8 and U4. The portion of this subunit that contains mud beds is located above U6, and the current-dominated, wavy-laminated calcareous lithofacies in this subunit occurs below U6. The very calcareous Subunit IIC correlates with the parallel seismic reflections between U4 and the Marshall Paraconformity at this site. Unit III lies below the high-amplitude Marshall Paraconformity reflector.

One objective of drilling on the shelf was to test the hypothesis that these contrasting characteristics of sequence boundaries and seismic facies above and below $\sim$ U9 occur because the paleoshelves of U9 and the underlying sequence boundaries were not suba- 
erially exposed at lowstand, whereas those above U9 may have been exposed, probably because of increasing eustatic amplitudes during the Pleistocene. The lithologic contrasts between Units I and II at shelf Sites U1351, U1354, and U1353 appear to broadly support this hypothesis, with the heterolithic sediments of Unit I representing deposition under conditions of fluctuating sea level since the mid-Pliocene. The fact that the transition is gradational also implies that the change in processes operating to produce these sediments is also gradational and not an abrupt change from one type of process that produces rounded shelf-slope breaks to one that produces sharp shelf-slope breaks.

The change in lithology between units is mirrored in the percentage of carbonate components, as estimated from smear slides and thin sections and measured using X-ray diffraction (XRD) and coulometry. The carbonate percentage in Unit I is high and variable (Fig. F16). The carbonate percentage in Unit II at shelf sites is low and only variable at the top of the unit, whereas it is moderate and less variable at slope Site U1352 (Fig. F16). At shelf Site U1351, the carbonate percentage begins to increase downhole, which is a reflection of the shift of depositional environment toward the slope with depth at this site. At slope Site U1352, the carbonate percentage also increases downhole, reflecting a rise in oceanicity (planktonic foraminiferal abundance) of the depositional environment (Fig. F16). Subunit IIC and Unit III are both limestones, deposited in truly oceanic environments, with little to no terrigenous sediment input.

\section{Correlation to Site 1119}

Site 1119 is located $\sim 35 \mathrm{~km}$ northeast of Site U1352 in slightly deeper water $(\sim 400 \mathrm{~m})$ but essentially along strike and in a similar upper slope position, $\sim 5$ $\mathrm{km}$ from the modern shelf-slope break (Shipboard Scientific Party, 1999b). The stratigraphic succession at Site 1119 was divided by shipboard scientists into three lithologic units that correspond to units defined on seismic profiles across the site. Unit I, interpreted as slope-drape deposits, extends from 0 to 88 $\mathrm{m}$ and ranges in age from 0 to $0.42 \mathrm{Ma}$. It comprises beds of silty sand and hemipelagic silty clay (mud) deposited on the slope. The underlying Unit II comprises drift deposits of silty sand and glacial silty clay. Unit II is divided into three subunits according to the nature of the drift deposits (composition and sedimentary structures) and their correlation with three seismically defined drift packages. The last major sandy interval at $\sim 400 \mathrm{~m}(\sim 2.5 \mathrm{Ma})$ and the underlying noncalcareous mudstone marks the boundary between Units II and III, the former being more sand rich and more calcareous. This boundary roughly corresponds to the top of a series of strong reflectors that marks the top of another drift sequence.

In thickness, lithology, and seismic character, Unit I at Site 1119 roughly corresponds to Subunit IA at Site U1352. Seismic facies mapping between the sites suggests that the drift packages composing Unit II at Site 1119 are different from those at Site U1352 (Lu and Fulthorpe, 2004) and that there is a significant difference in the thicknesses of the seismic sequences between the sites. Subunit IB is interpreted as a transitional slope/drift facies, becoming more drift dominated into Subunit IC.

The major units at both sites are roughly defined by carbonate content, with Unit I at Site 1119 and Subunit IA at Site U1352 exhibiting generally lower minimum and lower maximum carbonate values than the lower units at each site (cf. fig. F24 in Shipboard Scientific Party, 1999b; Fig. F18). Comparison suggests that Units II and III at Site 1119 roughly correspond with Subunit IB and the top of Subunit IC at Site U1352. A distinctly low carbonate interval at $\sim 430 \mathrm{~m}$ at Site 1119 corresponds to a similar low-carbonate interval occurring at $\sim 620 \mathrm{~m}$ at Site U1352.

\section{Potential sequence boundaries in cores Shelf sites (U1351, U1353, and U1354)}

Finer scale correlations between lithology and seismic interpretations are also possible. Correlation of specific lithologic features with seismic sequence boundaries will be improved by postcruise analysis, but some intriguing relationships can be drawn based on shipboard observations. Lithologic contacts and associated sediment packages were identified near the predicted depths of seismic sequence boundaries at all sites (Figs. F19, F20). Identification was based on changes in lithologic composition, the presence of reworked sediments, and the nature of the contacts. Basal surfaces were not always recovered-for example, in zones where recovery was poor because of the (inferred) presence of sand. In such cases, the surfaces were picked based on the presence of sand (or the assumption of washed-out sands) and correlation to wireline logs. Because of time restrictions on board ship, surfaces were only examined close to the predicted depths of seismic sequence boundaries; therefore, the lithologic surfaces identified here are implicitly linked to the predicted occurrences of sequence boundaries identified on the seismic profiles ( $\mathrm{Lu}$ and Fulthorpe, 2004). A similar approach was used during ODP Legs 150 and 174A, the objectives of which were also the study of sea level changes. Postcruise study will attempt to clarify the exact relationship of all lithologic surfaces and 
facies associations to sea level changes and seismic stratigraphy. The numbering system used in the site chapters, tables, and summary diagrams consists of a hole-specific prefix and a surface designation (e.g., U1351A-S1) that links each surface to a seismic sequence boundary (Figs. F19, F20); therefore, these lithologic surfaces and associated sediments are thought to be correlative between sites across the transect.

Candidate sequence boundaries are best identified in lithologic Unit I at each site, where recovery was highest (Fig. F17). For example, the lithologic surfaces of Unit I at Site U1351 are overlain by a series of lithofacies associations composed of upward-fining shelly sandy mud topped by regressive coarsening-upward sandy mud. Our working model is that the package is a transgressive wave-eroded ravinement surface overlain by a lag deposit corresponding to a transgressive systems tract. Subsequent highstand mud units are topped by the regressive coarsening-upward sediments. The facies assemblage includes decimeter- to centimeter-thick clay beds similar to those attributed to rapid deposition by flood events on modern shelves near sediment-rich fluvial systems. Truncated versions of this facies association lacking the regressive highstand phase occur in the uppermost $30 \mathrm{~m}$ at Site U1352, suggesting more frequent erosive episodes or nondeposition of this facies. There are more such truncated facies associations than there are seismic sequence boundaries, and it is therefore possible that some of the truncated facies associations may represent higher order cycles or autocyclicity related to migration of distributaries and/or shelf depocenters. The facies associations, both complete and truncated, are similar to those known from the Wanganui Basin, between the North and South Islands of New Zealand (Abbott and Carter, 1999; Saul et al., 1999; Abbott et al., 2005; Naish et al., 2005).

Unit I surfaces at Site U1351 may be correlative with U19-U11 (Fig. F20). The geometries of U19-U11, as well as paleoenvironmental interpretations from biostratigraphy, show that these surfaces developed on the middle to outer shelf, where eustatic fluctuations had the most significant direct impact. In contrast, surface U1351-S8 and the underlying strata formed when the position of Site U1351 was on the outermost shelf, progressively migrating (downhole) to the upper slope. Consequently, U1351-S8 is less sharp than U1351-S1 to U1351-S7, and reworked sediments are more difficult to identify below U1351-S8.

These lithologic surfaces were also identified in Unit II at Site U1351, although cemented intervals occur, some of which may correlate with seismic sequence boundaries. Diagenetic changes begin in the lower part of Unit I (at $\sim 150 \mathrm{~m}$ ), with authigenic carbonate cements and limestone concretions. Unit II is dark greenish gray very fine sandy mud and greenish black to dark greenish gray mud. Shells are less frequent below $\sim 350 \mathrm{~m}$ and are absent below $\sim 890 \mathrm{~m}$, probably reflecting the downhole shift from shelf to slope environments. The indurated clayey or sandy mud found in some core catchers in the lower part of the unit was drilling related, caused by frictional heating and baking by the XCB cutting shoe. However, other indurated intervals represent in situ carbonate cementation. These nodules or concretions are present throughout the unit, particularly below $750 \mathrm{~m}$. These have no clear relationship to intervals of low recovery.

The facies associations linked with seismic sequence boundaries at Site U1351 may also be present in Unit I at Site U1353, but they are not as prominent. The uppermost three, and possibly four, surfaces identified at Site U1353 correlate well with U19-U16 (Fig. F20). Surface U1353-S4 was not recognized in cores because of low recovery, but a biostratigraphic hiatus that is potentially correlative with U16 was recognized. Correlations of other surfaces and associated sediment packages at Site U1353 with seismic sequence boundaries remain tentative because of poor recovery (Fig. F17). Recovery from below $80 \mathrm{~m}$ at Site U1353, the most landward of the shelf sites, was either low or involved significant cave-in of overlying shell hash. The dominant recovered facies is mud, interpreted mostly to represent a highstand facies. Sandy intervals represent transgressive or regressive periods, whereas the shell hash, even when muddy, probably formed as a transgressive shoreface deposit. Although sediment recovered from Unit II was predominantly muddy, recovery was low and other lithofacies may have been present. The mud suggests deposition on a shelf below the fair-weather wave base, and the lack of abundant shell debris suggests that the setting was more distal than it was during deposition of Unit I. The sediment source for terrigenous sediments of both Units I and II at Site U1353 appears to have been the Torlesse graywacke to the west. This contrasts with sediments in Unit II at outer shelf Site U1351 and Subunit IB and Unit II at slope Site U1352, which include a major contribution from the Otago Schist to the south.

Site U1354 facies associations are similar to those at the other shelf Sites U1351 and U1353. Several potential unconformities were recognized within Unit I. U19-U15 were intersected in both Holes U1354A and U1354B at depths comparable to those predicted (Fig. F20). The strongest correlation of lithologic surfaces to seismic sequence boundaries was 
found at Site U1354: a burrowed probable sequence boundary in the same interval containing the Brunhes/Matuyama boundary that corresponds to U16. A $\sim 0.3$ m.y. gap that encompasses the Jaramillo normal chron, as demonstrated on nannofossil evidence, corresponds to U15. Furthermore, other older seismic sequence boundaries correspond to erosional gaps in the succession. In many cases, more than one candidate surface in the core was correlative with seismically mapped surfaces. These stratal relations suggest greater preservation of sediment at Site U1354, which could potentially contribute to an understanding of how sequence boundaries form and evolve. Correlations with seismic sequence boundaries therefore remain tentative, but good recovery in the uppermost $250 \mathrm{~m}$ at Site U1354 should allow for improved correlation between lithologic features and U19-U10. As at other Expedition 317 sites, poor recovery in the lower part of the hole makes coreseismic correlation more difficult.

\section{Lithostratigraphic correlation of shelf sites}

Packages of lithofacies can be tracked across the shelf between the three shelf sites, from Site U1353 in water depths of $\sim 85 \mathrm{~m}$, through Site U1354, to Site U1351 in water depths of $\sim 122 \mathrm{~m}$ (Fig. F21). Generally, the landward Holes U1353B and U1354B show coarsening-upward trends. Muddy sand, presumably of Holocene age, drapes the shelf but thins offshore from 9 to $4 \mathrm{~m}$ thick. A similar trend is evident in a layer of very fine, well-sorted quartz sand, which thins offshore from nearly $10 \mathrm{~m}$ thick in Hole U1353B to $2 \mathrm{~m}$ thick in Hole U1351B. These sedimentation patterns are consistent with both the Holocene eustatic rise and a decrease in sedimentation rates at middle and outer shelf settings. Additional shore-based studies will provide insight into the numerous depositional environments in which observed sedimentary cyclicity and sediments were deposited, as well as their correlation between sites.

\section{Slope site (U1352)}

A number of distinct lithologic surfaces and their associated sediments present at slope Site U1352 have the potential to be resolvable by seismic profiles. The uppermost $500 \mathrm{~m}$ of Site U1352 contains coarsegrained deposits that have been tentatively correlated to U19-U13. These remain the best-constrained boundaries. However, because of improved recovery at Site U1352 (Fig. F17), candidate slope surfaces were also identified in all lithologic units down to and including the Marshall Paraconformity (Fig. F19).

\section{Sedimentary cyclicity}

Seismic sequences and Milankovitch cyclicity

The relationship between high-frequency Milankovitch sequences and longer, seismically resolvable sequences remains an active and unresolved area of research. Saul et al. (1999) showed that for the Wanganui Basin, classic fourth- and fifth-order cyclothems are grouped together into third-order cycles controlled by basinwide tectonic rhythms. Alternatively, Miller et al. (2005) pointed out that some third-order cyclicity may be the manifestation of longer wavelength Milankovitch periodicities of 1.2 and 2.4 m.y. or of interference between these cycles.

Sequences drilled during Expedition 317 span the boundary between Milankovitch-scale cyclicity and longer third-order seismically resolvable cycles: periods of most seismic sequences range from $\sim 0.1$ (seafloor to U17) to 0.4 m.y. (U16-U7) (Table T2; Fig. F22). The two upper seismically delimited sequences on the Canterbury shelf (corresponding to the sequences overlying U19 and U18) almost certainly correspond to marine isotope Stages (MIS) 1-5 and MIS 6-7 sedimentary cycles, based on the magnetic susceptibility and natural gamma radiation (NGR) time series (Fig. F23). Surfaces U1351-S1 to U1351-S4 correlate with U18-U16, respectively. Between successive low spikes in this interval, gamma radiation shows four cycles of a gradual uphole increase followed by a decrease. These cycles correlate with fining- to coarsening-upward facies associations, which are formed by one cycle of transgression and regression (e.g., U1351-S2 to U1351-S4; Fig. F19). Based on biostratigraphic datums and the inferred position of the Brunhes/Matuyama boundary $(\sim 70 \mathrm{~m}$ at Site U1351), we can speculate that these sequence boundaries formed during periods of low global sea level and perhaps correlate with three of the four MIS 8, 10, 12, and 16 (Fig. F24). Three distinct intervals of low gamma radiation and high resistivity in wireline logging data across the three shelf sites correspond well to the predicted depths of U12, U11, and U10 (Fig. F25), which are also well resolved in preliminary synthetic seismograms generated from the logs. These features, which most frequently coincide with intervals of poor core recovery, appear to be associated with sand, shell, and gravel beds several meters thick that may be laterally continuous across the shelf.

Postcruise analysis, including improved age control for deeper sequence boundaries, will document and clarify the probable relationship between seismic sequences and Milankovitch cycles. Careful study will be needed to distinguish lithologic changes corre- 
sponding to genuine Milankovitch cyclicity from those resulting from autocyclic variation within cycles controlled by sedimentary changes of local significance. It is already clear that Expedition 317 data will provide important insights into the hierarchy of sedimentary cyclicity and into how and why certain cycles and/or periodicities are preferentially imaged using seismic data.

\section{Pleistocene to Holocene glacial-interglacial cycles}

Expedition 317 shelf sites (landward to basinward: U1353, U1354, and U1351) provide highly significant high-recovery sections through the HolocenePliestocene for high-resolution study of recent glacial cycles in a continental shelf setting. The smaller scale cycles penetrated during Expedition 317 drilling are similar in part to the Milankovitch-scale rhythms documented at nearby Site 1119 (Shipboard Scientific Party, 1999a; Carter and Gammon, 2004) and the New Jersey shelf (McHugh and Olson, 2002) and correspond to cycles with inferred lengths of 100,000 and 40,000 years. The seismic stratigraphy of the sequences deposited during the last (MIS 1-5) and penultimate (MIS 6-7) glacial-interglacial cycles on the Canterbury and Otago shelves has been described by Browne and Naish (2003) and Osterberg (2006).

Cycles drilled during Expedition 317 have differing sedimentary architectures depending on whether they were deposited seaward (Site U1352) or landward (Sites U1353 and U1354) of the inferred position of the last glacial lowstand shoreline $(\sim 125 \mathrm{~m})$. Site U1351 at $122 \mathrm{~m}$ water depth is located near the lowstand shoreline. Cycles at slope Site U1352 are always seaward of the lowstand shoreline. The main sedimentary facies association on the slope is composed of a sharp basal contact with sand-filled Thalassinoides burrows overlain by a few decimeters of shelly sand that grades upward into sandy mud. Similar cycles at Site 1119 were shown to contain temperate-water planktonic foraminifers in the basal sand (Shipboard Scientific Party, 1999a), with a colder water microfauna in the intervening muds; these facts are consistent with each cycle representing a full interglacial-glacial rhythm (though perhaps with a diastem of a few thousand years, represented by the sharp, burrowed bases of the sand units). These rhythms are interpreted as resulting from oscillations in flow intensity of cold-water SAMW, perhaps linked also to migrations of the Southland (Subtropical) Front across the site (Carter et al., 2004b). The rhythms also have to be influenced by terrestrial sediment supply, which is likely highest at lowstands and minimal to absent during highstands.

Glacial-interglacial deposits landward of the position of the lowstand shoreline are well developed in the upper parts of Sites U1353 and U1354. These are composed of a sharp and sometimes burrow-penetrated base, inferred to sometimes represent a shoreface ravinement surface, overlain by wellsorted sands as thick as several meters that grade rapidly up into sandy siltstone and siltstone. A pedogenic profile may be preserved below one or more of the ravinement surfaces that coincide with seismic sequence boundaries; if confirmed, this would be an unusual circumstance because virtually all of the Pleistocene sequence boundaries in the onland Wanganui Basin are characterized by sharp (albeit often burrowed) marine ravinement surfaces cut during transgression, and only one soil profile has been recorded (Abbott, 1992).

Some basal sandy units have a lower shelly portion or possess a shell-hash facies similar to the Type A transgressive shell beds described from middle Pleistocene cyclothems in the onland Wanganui Basin (Abbott and Carter, 1994). The associated mollusk faunas are firmly indicative of a proximal shorefacebeach environment for the sandy and shelly units (Austrodosinia, Phacosoma, Anchomasa, Maoricolpus, and Alcithoe) and a distal shoreface-inner shelf environment (Atrina, Dosinia lambata, Divaricella, Maorimactra, Scalpomactra, Antisolarium, and Stiracolpus) for the slightly deeper water siltstones.

Overall, the sedimentary cycles penetrated in the upper parts of Sites U1353 and U1534 show striking similarities to Pleistocene cyclothems described from the Wanganui Basin. Although in detail individual cycles display differing sedimentary architectures that await full description and interpretation, elements of the Castlecliff motif (Abbott and Carter, 1999; Saul et al., 1999) and the Birdgrove and Maxwell motifs (Abbott et al., 2005) may all be represented.

Located close to the lowstand shoreline, Site U1351 displays cyclicity characteristic of the more shoreward facies associations in its upper part and of the upper slope facies associations deeper in the hole. However, the uppermost cycles at Site U1351 are thicker and represent deeper water mud facies settings than those of their shelf counterparts at Sites U1353 and U1354, as would be expected. Some Site U1351 cycles coarsen upward into sands before being truncated by the superjacent sequence boundary, in similar fashion to Pliocene cycles described from the Wanganui Basin (Naish et al., 2005). 


\section{Sedimentary processes}

One goal of Expedition 317 was to provide insights into the role of contour-current deposition in a location where prominent sediment drift geometries are absent. Slope Site U1352 is most relevant to this question, but the deeper parts of Site U1351 also sampled slope facies between U6 and U8.

Northeasterly flowing currents (Southland Current, inboard of the Subtropical Front, and a gyre of the Subantarctic Front) are active today. At present, the core of the Southland Current is over the $\sim 300 \mathrm{~m}$ isobath (Chiswell, 1996). The local gyre of the Antarctic Circumpolar Current circulates clockwise within the head of Bounty Trough parallel to the Southland Current to at least $900 \mathrm{~m}$ (Fig. F2) (Morris et al., 2001). The sediment drifts in the northern part of the Canterbury Bight, as well as outcrop evidence of current-related deposition, suggest that similar currents have been active for the last $30 \mathrm{~m}$.y.

Early Pliocene and late Miocene nannofossil assemblages at Site U1351 contain reworked older material, some as old as Oligocene, but mainly early to middle Miocene. The downhole increase in reworking began while paleowater depths were still relatively shallow (inner to middle shelf) and before the downhole transition from shelf to upper slope facies, between U8 and U7 ( 725 m), where paleowater depths became more equivalent to those influenced by modern ocean currents. Nannofossils are small and easily transported. Reworked nannofossils at Site U1351 may have been reworked from the Campbell Plateau, where Miocene sediment is shallowly buried and may have been exposed. This suggests an alongstrike component of deposition.

A nearly complete Neogene continental slope sedimentary record dominated by pelagic to hemipelagic sedimentation with minor traction and gravity flow sediments was cored at slope Site U1352, as was a condensed late Eocene to early Oligocene section below the Marshall Paraconformity. This site represents a downhole record of unlithified sediments transitioning to lithified carbonates at depth. The gradual downward transition in lithofacies from more siliciclastic-rich Holocene-Pleistocene muddy facies into pelagic limestones and glauconitic marlstones and marls appears to reflect the downhole transition, seen on seismic profiles, from an upper slope location on a clinoformal margin with sharp shelf-slope breaks in the Holocene-Pleistocene toward a toe-ofslope location on a margin with more rounded shelfslope breaks and a more gently inclined slope in the Miocene (Fig. F14). The lower carbonate content in the upper part of this interval may be linked to higher terrigenous input related to the uplift of the Southern Alps and/or Neogene climate change.

Subunit IA at Site U1352 may be composed of sediment gravity flows that fed a series of lowstand deltas. Evidence for this is found in the composition of the sediments. The gray sand beds of Subunit IA have a Torlesse Terrane mineralogy, indicating that they are derived from the Canterbury region. This contrasts with the rest of Site U1352 (Subunit IB and below) and with Site U1351, which appear to be predominantly sourced from the Otago Schist to the south. Subunit IB also seems likely to contain evidence of mass transport deposition, although the equivalent interval at Site 1119 was interpreted as being contourites. Subunit IB may be a transitional (downhole) downslope-to-drift interval culminating in Subunit IC, which shows evidence (well-sorted, very fine-grained sand fraction) consistent with considerable transport distance and seismic evidence of sediment drift deposition.

Unit II is dominantly calcareous (sandy marl and marlstone). Hemipelagic to pelagic sediments of Subunit IIA (709-1189 m) may have been deposited as sediment drifts, based primarily on seismic evidence downslope and along strike (Fig. F14) (Lu and Fulthorpe, 2004): diagnostic sedimentary structures are rare, in part because of extensive bioturbation. More calcareous lithologies may represent condensed nondepositional intervals within the drifts. The increasing frequency of calcareous intervals toward the base of Subunit IIA may reflect reduced rates of terrigenous deposition near clinoform toes.

Subunit IIB (1189-1694 m) contains intermittent current-generated structures (wavy laminations and ripple cross laminations) interpreted as contourites. An alternation of light-colored marlstone with darker mudstone suggests switching between more hemipelagic carbonate (highstand?) sources and terrigenous (lowstand?) sources. Subunit IIB also contains mass transport complexes (slumping) near its base. Subunit IIB lithologies therefore suggest a complex interplay between along-strike and downslope sedimentary processes.

Subunit IIC marlstones and limestones lack traction features, suggesting pelagic deposition from suspension in deep water. Micropaleontology indicates a lower bathyal setting. The intercalated glauconitic sandstone laminae characteristic of this unit are inferred to be injected sands derived from the underlying Oligocene greensand (Kekenodon Group), which was not recovered at this site. The Marshall Paraconformity (see below) forms the boundary between Units II and III. Unit III is Amuri Limestone-equiva- 
lent pelagic nannofossil limestone deposited in lower bathyal depths.

\section{Marshall Paraconformity}

The Marshall Paraconformity is a regional unconformity terminating the postrift transgressive phase and capping the widespread Amuri Limestone. The paraconformity has been dated at its onshore type section using strontium isotopes as representing a hiatus between 32.4 and $29 \mathrm{Ma}$ (Fulthorpe et al., 1996), where it occurs at the base of middle-upper Oligocene cross-bedded glauconitic sand (Concord Formation) and calcarenite limestone (Weka Pass Formation). The paraconformity was the deepest target of Expedition 317 drilling and was hypothesized to represent intensified current erosion or nondeposition associated with the initiation of thermohaline circulation (Deep Western Boundary Current) and associated shallower circulation upon the opening of the seaway between Antarctica and Australia ( 33.7 Ma) prior to the opening of the Drake Passage (Carter, 1985; Fulthorpe et al., 1996; Carter et al., 2004c).

The Marshall Paraconformity is represented by a lithologic change at $1853 \mathrm{~m}$ in Hole U1352C, a record penetration for a Deep Sea Drilling Project (DSDP)/ ODP/IODP hole drilled during a single expedition (total depth was $1927 \mathrm{~m}$ ). The paraconformity marks the boundary between overlying lower Miocene glauconitic limestone and underlying lower Oligocene recrystallized pelagic nannofossil limestone containing trace fossils and stylolites, equivalent to the onshore Amuri Limestone. Recovery was low across the paraconformity, which is represented by a decimeter-scale rubble zone in the recovered core. No equivalent to Concord Formation glauconitic sand was recovered, although logs from the Clipper well suggest the presence of a boundary sand layer. The hiatus at the paraconformity is estimated to be 11-12 m.y. at Site U1352, conforming with previous observations that the hiatus is longer offshore than at the type section, perhaps owing to greater currentinduced erosion at deeper water locations (Shipboard Scientific Party, 1999a; Carter et al., 2004c). Hole U1352C terminated in upper Eocene (35.2-36.6 Ma) limestone with clayey interbeds.

Drilling results indicate that the Marshall Paraconformity correlates with the "Green" reflection observed by industry interpreters (e.g., Hawkes and Mound, 1984). Our original interpretations assumed a correlation with a reflection $\sim 160 \mathrm{~m}$ shallower than "Green." This, in turn, means that "Green" does not represent the base of the Amuri Limestone, as was previously inferred.

\section{Biostratigraphy}

Subtidal to lower bathyal sediments of Holocene to late Eocene age (0-36 Ma) were cored in a transect across the Canterbury Basin continental shelf and slope. Sequence stratigraphic processes influenced calcareous nannofossil and planktonic foraminiferal assemblages, which is strongly reflected in the overall abundance, preservation, and assemblage variations in relation to lithology. These variations may have been influenced by a number of factors, including global climate, local paleoceanography, changes in sea level, and tectonic uplift along the Alpine Fault. In general, Expedition 317 age assignments relied on nannofossils from the Holocene to middle Pliocene and planktonic foraminifers from the early Pliocene to late Miocene. Both fossil groups were integral for biostratigraphic control from the middle Miocene to Eocene. The following biostratigraphy and resulting interpretations are described in the order of sequences drilled, from youngest to oldest.

\section{Holocene}

The Holocene was not identified biostratigraphically, but, based on lithologic evidence, the thickness of Holocene sediments decreased oceanward, from a maximum of $9.9 \mathrm{~m}$ at the innermost shelf Site U1353 to $1.2 \mathrm{~m}$ at slope Site U1352. Mudline samples from Sites U1352, U1353, and U1354 contained temperate planktonic foraminiferal assemblages consistent with the Holocene highstand and the present-day landward position of these sites relative to the Southland Front.

\section{Pleistocene}

Calcareous nannofossil dating provided robust age control through the Pleistocene and contributed to the identification of several intra-Pleistocene hiatuses at all three shelf sites. The hiatuses potentially correspond to seismic surfaces inferred to represent sequence boundaries (Fig. F22). Calcareous nannofossil abundances appear to be cyclical. Maximum abundances are thought to be correlated with highstands and lowest abundances with lowstands. This is consistent with observed lithologic variations. In general, greenish gray sandy marls were associated with high numbers of calcareous nannofossils and with temperate populations, whereas gray sandy muds were associated with low numbers of nannofossils and cool-water populations. The Pleistocene section at slope Site U1352 was expanded relative to the shelf sites, and the hiatuses seen at the shelf sites were either absent or less pronounced at Site U1352.

Planktonic foraminiferal assemblages through the Pleistocene sections of shelf Sites U1351, U1353, and 
U1354 were generally characterized by low abundances and small, thin-walled neritic forms typical of deposition under inner neritic conditions (Fig. F26). These low abundances are consistent with an offshore westerly wind pattern, similar to that of the present day. However, higher abundances indicative of deposition under outer neritic or extraneritic conditions were noted in some samples, especially greenish gray sandy marls. These assemblages included larger temperate forms, whereas interbedded gray calcareous muds were dominated by smaller cold-water forms, including the subantarctic species Neogloboquadrina pachyderma. Similar alternations between temperate and cold-water assemblages were noted throughout the Pleistocene succession. Age-diagnostic planktonic foraminifers that need deep water to complete their reproductive cycles were generally rare, which contributed to poor planktonic foraminiferal dating through the Pleistocene. Planktonic foraminifers were better represented at slope Site U1352 (Fig. F26), but temperate species that facilitate a robust correlation with the New Zealand timescale were relatively rare and were generally only found in greenish gray sandy marls. There were few age-diagnostic species in intervals of gray calcareous mud.

\section{Pliocene}

The Pliocene/Pleistocene boundary is unconformable at all four sites and is a major correlation surface close to the predicted depth of U13 (Table T2). Biostratigraphic evidence indicated that most, if not all, of the upper Pliocene was missing. The thickness of the Pliocene succession was poorly constrained at the innermost shelf Site U1353, but at middle shelf Site U1354 the middle Pliocene was $50 \mathrm{~m}$ thick, and the lower Pliocene was at least $185 \mathrm{~m}$ thick. At the outermost shelf Site U1351, where the Pliocene was represented by a progradational middle and lower Pliocene succession, the middle and lower Pliocene sections were 100 and $580 \mathrm{~m}$ thick, respectively. The same progradational succession at slope Site U1352 was 390 and $380 \mathrm{~m}$ thick, respectively.

Standard calcareous nannofossil zonation schemes (typically derived from mid- to low latitudes) could not be applied to the Pliocene section at any site in spite of their published presence at even higher southern latitudes. This is attributed to cold subantarctic waters that strongly influence the oceanographic setting of the Canterbury Basin. Age-diagnostic planktonic foraminifers associated with the Globoconella sphericomiozea-puncticulata-inflata group are common throughout the Pliocene section of slope Site U1352 and the lowermost Pliocene section of outer shelf Site U1351. This, in combination with calcareous nannofossils and seismic stratigraphy, provided age control through the Pliocene sections of the shallower shelf Sites U1353 and U1354.

At Site U1351, planktonic abundances increased downhole throughout the lower Pliocene section below $590 \mathrm{~m}$, marking a downhole change from shelfal to slope sedimentation and reflecting oceanward migration of the shelf break over the site. Significantly, a major influx of reworked late-middle Miocene calcareous nannofossils occurred in this same interval. The absence of low-latitude zonal markers in the reworked calcareous nannofossil assemblage indicated that it must have come from a cold southerly source. This has implications concerning the role of alongstrike sediment transport, the focus of which appears to be at the shelf break.

Similar increases in planktonic foraminiferal abundance related to slope deposition and reworking of Miocene calcareous nannofossils were not seen in the Pliocene sections of the shallower shelf sites. In fact, the Pliocene-?upper Miocene section of the most landward Site U1353 is largely devoid of microfossils, except for occasional pulses of calcareous nannofossils and planktonic foraminifers.

\section{Miocene}

Upper Miocene sediments were recovered at Sites U1351, U1352, and U1353, although the dating and subdivision of the Miocene was very poorly constrained at the latter site. The Miocene/Pliocene boundary was identified between $\mathrm{U} 7$ and $\mathrm{U} 6$ and is presumably conformable.

Reworked calcareous nannofossil material continued through the $204 \mathrm{~m}$ thick progradational upper Miocene slope succession, except reworked taxa were mid-Miocene to Oligocene in age. The continuity of the upper Miocene section at Site U1351 was interrupted by a major hiatus between U6 and U5, where a gap of $\sim 5$ m.y. exists between 5.6 and $10.5 \mathrm{Ma}$ (Table T2).

At slope Site U1352, the progradational upper Miocene section was $220 \mathrm{~m}$ thick, overlying a $190 \mathrm{~m}$ thick middle Miocene section and a $170 \mathrm{~m}$ thick lower Miocene section. Deposition at this site occurred in a lower to basal slope environment under oceanic conditions (Fig. F26). The high abundance of planktonic foraminifers and the presence of bolboformids contributed to reliable dating at this site, although preservation was generally poor, especially in intervals of cemented sandy marl. Calcareous nannofossil assemblages in the Miocene section of Site U1352 included pulses of reworking, but the total amount of reworked material was less than that at Site U1351. The major hiatus recognized between U6 
and U5 in the lower upper Miocene section at Site U1351 was also recognized at Site U1352, although it occurs above, rather than below, U6. This suggests that the seismic mapping of U6 needs review. A significant hiatus was also noted between the middle and upper Miocene at Site U1352, where at least 1.3 m.y. was missing. The same hiatus may have also occurred in the lowermost part of Site U1353, although ages were poorly constrained at that site, which reduces the reliability of the correlation. A marked change to warmer planktonic foraminiferal and calcareous nannofossil assemblages occurred in the lower Miocene below the level of the hiatus. This coincided with the return of standard nannofossil zonal markers in the lower Miocene. Another major hiatus associated with the Marshall Paraconformity was recognized at the base of the Miocene succession, where $\sim 12$ m.y. was missing. At Site 1123, located on the deep northeast slope of Chatham Rise $\sim 1000 \mathrm{~km}$ north-northeast of Site U1352, a similar amount of time was missing at the Marshall Paraconformity (Shipboard Scientific Party, 1999a).

\section{Oligocene to Eocene}

Slope Site U1352 was the only site where Oligocene and Eocene sediments were recovered. Microfossil preservation was generally poor, but nannofossil and planktonic foraminifer markers were identifiable, providing solid age control. The extremely high abundances of planktonic foraminifers throughout this succession are consistent with basin floor deposition under an open oceanic watermass (Fig. F25). The Oligocene/Miocene boundary is unconformable (Marshall Paraconformity). This hiatus extended from lower Miocene (18-19 Ma) to lower Oligocene (30.1-32.0 Ma), a gap of $\sim 12$ m.y. The Eocene/Oligocene boundary is also unconformable, falling within a hiatus of $\sim 2.3 \mathrm{~m}$.y. from the lower Oligocene (32.5$32.9 \mathrm{Ma})$ to the upper Eocene (35.2-36.0 Ma) (Fig. F22). The age at the bottom of the hole is 35.2-36.0 Ma.

\section{Oceanicity}

Planktonic foraminiferal abundance provides a measure of overlying oceanicity and serves as a measure of the distance from land in paleogeographic reconstructions. Test size, diversity, and composition of the planktonic foraminiferal assemblages also serve as proxies for oceanicity.

Oceanicity records from Expedition 317 sites were markedly different, except in the Pleistocene. The three shelf sites all exhibited high-amplitude Pleistocene fluctuations in planktonic abundance (Fig. F26). These high-amplitude peaks may correspond to highstands and could potentially be correlated across the shelf.

The Pliocene-Miocene succession of landward shelf Site U1353 was characterized by the absence of planktonic foraminifers, except for a single specimen found in the last sample (Fig. F26). This is unusual even in such a shallow marine environment and is in marked contrast with the continental shelf in the Taranaki Basin, where planktonic foraminifers were relatively common. This difference is attributed to the prevailing westerly wind pattern, which in Taranaki drives planktonics inshore and in Canterbury drives them offshore. Turbid water over the Canterbury shelf, related to high-volume river discharge, may also have contributed to the paucity of planktonic foraminifers.

The Pliocene-Pleistocene record of oceanicity at shelf Site U1354 was similar to the correlative succession at Site U1353, except planktonic abundances were slightly higher (Fig. F26). This is consistent with the site location closer to the shelf break.

Planktonic abundances throughout the lower Pliocene-Miocene succession of outermost shelf Site U1351 increased from inner neritic to suboceanic values (Fig. F26). The onset of this downhole increase in the lower Pliocene occurred when the shelf break was located near the site. The subsequent increase in oceanicity below this level suggests that the site was located progressively more oceanward of the shelf break. This trend was also reflected in the test size and diversity of planktonic foraminiferal assemblages. Second-order high-amplitude perturbations in the oceanicity record of the slope succession may be related to changes in sea level, although more detailed sampling is needed.

The abundance of planktonic foraminifers at slope Site U1352 generally increased downhole from suboceanic values in the Pleistocene to fully oceanic values in the Oligocene (Fig. F26). This is consistent with deposition on the mid- to lower slope and possibly the basin floor in the lowermost part of the succession. It also indicates that the site was always located oceanward of the shelf break.

\section{Benthic foraminifers and paleowater depths}

Although their abundance varied, benthic foraminifers constituted the major microfossil component within the 150-1000 $\mu \mathrm{m}$ size fraction at all Expedition 317 sites. The preservation of benthic foraminifers was generally good in the Pleistocene, became poor to moderate in the Pliocene and Miocene at shelf Sites U1353, U1354, and U1351, and was poor in the Oligocene and Eocene at slope Site U1352. 
The Pleistocene assemblage was composed of mainly inner to outer shelfal taxa at shelf Sites U1351, U1353, and U1354 and outer shelf to upper bathyal taxa at slope Site U1352. Subtidal to inner shelfal assemblages alternated with mid- to outer shelfal assemblages at Sites U1351, U1353, and U1354, implying cyclic changes in water depth. General trends of deepening or shallowing can be provisionally correlated with some seismic sequence boundaries (Fig. F27). Pliocene assemblages at the shelf sites are similar to those of the Pleistocene, with marker species suggesting slightly deeper shelfal environments oceanward across the transect.

In spite of the poor preservation and rarity of earliest Pliocene to latest Miocene benthic foraminifers at slope Site U1352, assemblages suggested a downhole decrease in shelfal species and an increase in upper bathyal marker species. Deep middle to deep lower bathyal species were the main components in the middle Miocene. Water depths at slope Site U1352 therefore shallowed from lower bathyal to uppermost bathyal since the middle Miocene as the shelfslope sediment prism prograded out into the basin (Fig. F27). Early Miocene and Oligocene benthic foraminifers were too rare for reliable estimation of paleowater depths.

\section{Age-depth plots}

Age-depth plots (Figs. F28, F29, F30, F31) were created for each site using biostratigraphic datums, New Zealand stage determinations based on foraminiferal assemblages, and paleomagnetic reversal data at Site U1354. At all sites, age control data points were spaced too far apart to determine sedimentation rates with accuracy; however, average sedimentation rates were calculated over the gross intervals between major hiatuses, where the rate appeared to remain constant (dashed lines). These rates may be averaged over unresolved hiatuses, so the relatively low numbers may actually represent high rates of sedimentation separated by periods of nondeposition and/or erosion.

The pattern of sedimentation rates across the sites indicates relatively slow deposition during the early to middle Miocene (data mainly from slope Site U1352; Fig. F31), with one or more hiatuses in the late Miocene, dividing this succession from a latest Miocene to Pliocene period of rapid deposition across shelf sites (data from Sites U1354, U1351, and U1352; Figs. F29, F30, F31).

Note that the benthic foraminiferal datums included in the plots are in some cases likely to be strongly affected by environmental changes. An example of this effect is the highest occurrence (HO) of Hopkinsina mioindex at $1220 \mathrm{~m}$ in Hole U1352C (Fig. F31).
This datum (3.62 Ma) appears displaced from the rest of the data points in this zone, perhaps because the species occurs only in water depths greater than $\sim 1000 \mathrm{~m}$. This HO is therefore actually an indication that water depths in the depositional environment reached $1000 \mathrm{~m}$ at this horizon.

Hiatuses were identified by the biostratigraphy group based on the occurrence of multiple datums at a single stratigraphic level, as well as on "softer" data such as sudden changes in abundance, preservation, and faunal assemblages. Sometimes these hiatuses corresponded with lithologic changes or surfaces identified in the cores, but, more often, low recovery meant that unconformity surfaces were not recovered. The exception is Site U1354, where several sharp lithologic changes were recovered in intervals where biostratigraphy identified hiatuses; the good recovery allowed the identification of two unconformity surfaces between 60 and $80 \mathrm{~m}$ (Fig. F29), whereas at other sites only one unconformity was definitely identified. Otherwise, the unconformities first identified at Site U1351 were also identified at other sites, particularly a mid-Pleistocene unconformity (two surfaces at Site U1354), a significant unconformable surface at the Pliocene/Pleistocene boundary (identified at all sites), and a late Miocene unconformity (or possibly two, identified at Site U1352).

\section{Porosity and backstripping}

One of the goals of Expedition 317 was to provide the data necessary to allow quantitative analysis of subsidence and, ultimately, sea level change in the Canterbury Basin using two-dimensional backstripping. In addition to paleoenvironment and age data, backstripping requires an estimate of the history of sediment compaction. Porosity measurements reveal variations in compaction of mixed, largely terrigenous sediments as a function of both burial depth and location across the shelf to the upper slope (Fig. F32).

All sites showed rapid compaction in the upper several tens of meters, suggesting a rapid change from loosely to closely packed grains. Beneath this is a zone in which little porosity loss occurs with depth. The thickness of this zone increases from the middle shelf to the upper slope (Fig. F32). This zone is all but absent at landward shelf Site U1353, where compaction as a function of depth is most rapid. At upper slope Site U1352, two overlapping compaction trends were observed (Fig. F32). The coarser grained facies display rapid cementation and porosity loss, whereas interbedded finer grained sediments remain unlithified to greater depths and lose their porosity more slowly. Improved understanding of sediment 
compaction and diagenesis that arises from these data will be incorporated into backstripping models.

\section{Geochemistry}

The transect of four sites drilled during Expedition 317 provided the opportunity to study pore fluid and sediment geochemistry from middle shelf to upper slope settings spanning present-day water depths of 85-344 m. This contrasts with the majority of scientific ocean drilling sites, which involve coring in water depths of 1500-5000 m. Shelf sediments display variability imposed by glacial-interglacial changes in sea level and changes in conditions associated with discontinuities in sedimentation, including subaerial emergence, uplift, and erosion. These conditions introduce complications such as missing section and major changes in variables such as temperature and pressure that affect the ephemeral properties of pore fluids.

Many of the geochemical processes studied in the shipboard geochemistry program are driven by the microbially mediated remineralization of organic matter buried with the sediments. In addition, other processes increase with burial depth as unstable mineral assemblages are reorganized by dissolution and precipitation. By sampling and analysis at successive core depths, we attempted to piece together the dominant geochemical processes that have taken place in the sediments. The analyses are grouped conveniently by gas, liquid, and solid.

\section{Gas and shallow biogeochemical zones}

During Expedition 317, cores at all four sites were routinely sampled for traces of residual dissolved gas, both as a hydrocarbon safety procedure and as a sensitive technique to determine the status of the microbial and thermal degradation of organic matter. Combined with high-resolution water samples (taken in every section of recovered cores), this approach led to detailed profiles covering the biogeochemical zones of sulfate reduction, anaerobic oxidation of methane (AOM), and methanogenesis at all sites (Fig. F33).

Sites U1351 and U1352 are located farther offshore and have similar geochemical profiles distinct from those at Sites U1353 and U1354. At both sites a classic sulfate-methane transition (SMT) zone is located at $\sim 15-16 \mathrm{~m}$. In sediments below the SMT, sulfate is virtually absent, and methane concentrations increase dramatically from background levels in the low ppmv range to $>10,000 \mathrm{ppmv}$. Alkalinity at the SMT maximizes at 10 and $24 \mathrm{mM}$ for Sites U1351 and U1352, respectively (Fig. F33). The apparent levels of carbon oxidized and the low levels of ammo- nium and phosphate generated at Site U1351 suggest that sulfate reduction is primarily fueled by AOM, whereas at Site U1352 both AOM and organic matter oxidation are coupled with the removal of sulfate. Residual methane concentrations below the SMT remain constant at 10,000-20,000 ppmv for both sites, approximately equivalent to $4-8 \mathrm{mM}$ of methane per liter of pore volume, which probably represents only $5 \%-10 \%$ of actual subsurface dissolved gas contents. However, ethane levels (shown by the methane/ethane $\left[\mathrm{C}_{1} / \mathrm{C}_{2}\right]$ ratio) vary significantly. $\mathrm{C}_{1} / \mathrm{C}_{2}$ at Site U1351 increases gradually with depth and temperature, as expected, but $\mathrm{C}_{1} / \mathrm{C}_{2}$ ratios at shallow depths are unusually low (400-600). This suggests some combination of higher temperatures associated with warmer bottom waters, some removal of sediment at unconformities, preferential loss of methane by anaerobic oxidation, or gas loss from sands during core recovery and sampling. At Site U1352, which is located farther offshore on the slope, gas just below the SMT has a $C_{1} / C_{2}$ ratio of 16,000 , which is lower than most deepwater coring sites. The average $C_{1} / C_{2}$ ratio decreases by three orders of magnitude to $\sim 60$ at the bottom of Hole U1352C at $1920 \mathrm{~m}$. At an apparent discontinuity near $1390 \mathrm{~m}$, only very low gas content was found ( $40 \mathrm{ppmv}$ methane) and $\mathrm{C}_{1} / \mathrm{C}_{2}$ drops as low as 7 , mainly from the near absence of methane. Below the discontinuity the gas resumes the normal trend of residual methane contents (>10,000 ppmv). At both Sites U1351 and U1352, higher hydrocarbons $\left(\mathrm{C}_{3}-\mathrm{C}_{5}\right)$ were detected in increasing amounts with depth, apparent products of the low-temperature alteration of organic matter in the deeper cores.

Sites U1353 and U1354 are located on the shelf in water depths of 85 and $113 \mathrm{~m}$, respectively. Both sites are characterized by the absence or low levels of methanogenic activity in the uppermost $150 \mathrm{~m}$, leading to low methane concentrations (Fig. F33). At Site U1353 no hydrocarbons above background levels were detected, and sulfate remains close to seawater concentration, with the exception of slightly decreased sulfate in a lower salinity interval at 20$70 \mathrm{~m}$. No SMT is apparent, suggesting that either (1) methanogenesis did not occur in the sediments, (2) previously generated methane was lost when the shelf was emergent, or (3) methane was oxidized when sulfate was replenished by diffusion after a subsequent sea level rise. Alkalinity never rises above $6.5 \mathrm{mM}$ and declines gradually with depth.

Hydrocarbon monitoring at Site U1354 showed two peaks in methane, a small peak (23 ppmv) at 33$75 \mathrm{~m}$, and a large peak below $\sim 200 \mathrm{~m}$, where methane increased to $>20,000 \mathrm{ppmv}$. In both cases methane begins to increase when sulfate drops to zero, 
and the shallow methane peak disappears when sulfate reappears in the cores. These alternations of methanogenesis appear to be related to changes in sedimentation rate. The upper and lower methane zones correspond to periods of rapid sedimentation (200$400 \mathrm{~m} / \mathrm{m} . \mathrm{y}$.), during which sulfate was depleted and methane was generated. The intermediate interval $(60-178 \mathrm{~m})$ corresponds to periods of slower sedimentation $(<50 \mathrm{~m} / \mathrm{m} . \mathrm{y}$.$) , when pore waters could be$ replenished with sulfate by diffusion from overlying seawater.

\section{Interstitial water geochemistry}

Interstitial water was squeezed from sediments in most of the sedimentary sequence for the three shelf sites but only in the uppermost $1400 \mathrm{~m}$ of slope Site U1352. At this site pore water yields decrease from $\sim 2-5 \mathrm{~mL} / \mathrm{cm}$ of whole round squeezed in the shallower sediments to $<1 \mathrm{~mL} / \mathrm{cm}$ below $1200 \mathrm{~m}$, reflecting progressive compaction, porosity and water loss, and the general sediment to rock transformation. Pore waters in the Canterbury Basin have quite variable properties depending on site location on the transect.

Below the sulfate reduction zone calcium always increases with depth, but at different rates and to different values (Fig. F34). At Sites U1353 and U1354, the increase occurs mainly in the uppermost $200 \mathrm{~m}$ and reaches only moderate values $(<20 \mathrm{mM})$, whereas at Sites U1351 and U1352 the calcium increase is noticeably sharp (at $\sim 250$ and $\sim 500 \mathrm{~m}$, respectively) and reaches values of $30 \mathrm{mM}$ and higher in the deepest sediments at each site. These variations are likely related to carbonate diagenesis, and possibly contributions from deeper basinal brines, and are broadly consistent with dissolution of carbonates and the poor preservation of microfossils. More particularly, there is evidently some exchange of magnesium for calcium in the dissolution and reprecipitation of carbonates during diagenesis at Sites U1351 and U1352, as indicated by the greater declines in the $\mathrm{Mg} / \mathrm{Ca}$ ratio and the higher carbonate content at these sites.

Alkalinity, mainly as bicarbonate ion produced by oxidation of organic matter, always decreases with depth below the sulfate reduction zone and generally reaches values $<3 \mathrm{mM}$ below $200 \mathrm{~m}$ (Fig. F33), although this transition, together with the increase in calcium, occurs at $\sim 500 \mathrm{~m}$ at slope Site U1352.

Chloride and salinity generally co-vary, but there are other controls on sodium content. The salinity and chloride contents of pore water remain constant and near seawater composition throughout slope Site U1352, except for the deepest sample, which has a significantly lower chloride content. At Site U1351 the chloride becomes more concentrated than seawater between 50 and $200 \mathrm{~m}$ and again below $900 \mathrm{~m}$. The highest salinity and chloride values occur at Site U1354, where they increase throughout the sequence and reach values of 3.8 and $694 \mathrm{mM}$, respectively. The deepest samples from Site U1353 are also the most saline, but this site is also characterized by a salinity minimum in the uppermost $150 \mathrm{~m}$ that reaches $2.4 \mathrm{mM}$ or $70 \%$ of seawater at $\sim 50 \mathrm{~m}$. This less saline lens affects the pore water composition of several other ions, including sodium, potassium, and magnesium (Fig. F34). The presence of this less saline lens could be explained by either modern intrusion of meteoric water from land or by the historic remains of freshwater that was emplaced when the shelf was emergent and is now being slowly replaced by the downward diffusion of seawater. However, this less saline water lens is not present at the more seaward Sites U1354 and U1351. Water depths are $85 \mathrm{~m}$ at Site U1353, compared with $113 \mathrm{~m}$ at Site U1354 and $122 \mathrm{~m}$ at Site U1351. Global sea level was $\sim 125 \mathrm{~m}$ below today's sea level at the last glacial maximum about 20 k.y. ago, so both Sites U1353 and U1354 should have experienced periods of complete emergence. Therefore, the lack of less saline water at Site U1354 and its presence at Site U1353 are more likely explained by the modern intrusion of meteoric water from land, rather than by the historic remains of freshwater emplaced when the shelf was emergent.

Potassium concentrations decrease with depth at all four sites, starting from slightly higher than seawater values of $\sim 11 \mathrm{mM}$ in the shallowest samples (Fig. F34). The decrease to $<6 \mathrm{mM}$ is rapid within the uppermost $150 \mathrm{~m}$ at the shelf sites but is much more complex at the slope site, with an initial decrease in the sulfate reduction zone, an increase back to seawater values, and finally a steady decrease to $<4 \mathrm{mM}$ below $800 \mathrm{~m}$ (Fig. F34). The decrease in potassium, and to some extent sodium, is likely related to diagenetic glauconite precipitation, which is a common mineral at all four sites and usually appears around the depth of the potassium drawdown.

Silica and silicon concentrations are always $<1000$ $\mu \mathrm{M}$ and generally rapidly fluctuate in abundance in the uppermost $100 \mathrm{~m}$. At the slope site this variability persists throughout the section with interstitial water samples, but silica and silicon are more consistent and less abundant below $700 \mathrm{~m}$. At Site U1351 silicon concentration levels are $\sim 400-500 \mu \mathrm{M}$ below $100 \mathrm{~m}$, whereas they are $\sim 200 \mu \mathrm{M}$ at nearer shore sites. This suggests that silica mobilization and precipitation is more active nearer to shore, consistent with the lower carbonate and greater clastic component at these sites. 
Lithium concentrations generally increase with depth at all four sites, with very smooth profiles to $<100 \mu \mathrm{M}$ at Sites U1353 and U1354 and more complex patterns and higher overall concentrations at the two more distal sites. The lithium increases may be caused by dehydration reactions that removed lithium from clay interlayer exchange sites and in some cases are related to lithologic changes.

Barium concentrations increase rapidly in the shallowest samples $(<40 \mathrm{~m})$ and then generally remain steady until $>250 \mathrm{~m}$, below which they increase. At Sites U1353 and U1354 this increase never exceeds $10 \mu \mathrm{M}$, but barium concentrations are much higher $(>20 \mu \mathrm{M})$ in Site U1352 samples below $500 \mathrm{~m}$. Site U1351 has intermediate barium concentrations in the deeper sediments $(5-12 \mu \mathrm{M})$ but higher abundance (up to $23 \mu \mathrm{M}$ ) in the four shallowest samples, which so far remains unexplained.

Boron concentrations also increase with depth at all four sites, but to different values. Boron reaches $\sim 0.6$ $\mathrm{mM}$ in the deepest sample $(586 \mathrm{~m})$ at Site U1353, $1.26 \mathrm{mM}$ at $318 \mathrm{~m}$ at Site U1354, and maximum values of $4-5 \mathrm{mM}$ at Sites U1351 and U1352. Thus, there is a trend of higher boron farther offshore and deeper in the cores, which may be consistent with a diagenetic opal-A/opal-CT transition and microbial degradation of organic matter.

\section{Sediment geochemistry}

The sediments cored at Site U1351 show marked differences in geochemistry with depth, with higher carbonate, higher nitrogen, and lower sulfur above $200 \mathrm{~m}$ (Fig. F35). Organic carbon contents range from $<0.1$ to $1.5 \mathrm{wt} \%$, with more frequent higher values in the uppermost $200 \mathrm{~m}$. Pyrolysis characterization suggests the organic matter is dominated by degraded higher plant debris.

Analyses of sediment samples at Site U1352 also distinguished the clay-rich lithologic Unit I from the carbonate-dominated Unit II. Organic carbon content was generally low $(<0.6 \mathrm{wt} \%)$, with only a few samples having $>1 \%$ total organic carbon (TOC) (Fig. F35). The character of the organic matter changes from relatively labile volatile material in the shallower sediments to more stable proto-kerogen downhole, with evidence for increasing thermal maturity at total depth. The organic matter appears to be mainly terrestrial plant or degraded marine in origin.

At Site U1353 the average carbonate content is highly variable but generally is lower below $300 \mathrm{~m}$ (Fig. F35). The decrease in TOC in the uppermost $100 \mathrm{~m}$ can be correlated with intervals of increased alkalinity and decreased sulfate and might represent active biological oxidation. Pyrolysis characteriza- tion of organic matter suggests a major contribution from terrestrial plants, whereas ratios of TOC by difference $\left(\mathrm{TOC}_{\text {DIFF }}\right)$ to total nitrogen (TN) from elemental analysis are consistent with a significant marine influence.

Only 18 Site U1354 sediment samples were analyzed for carbonate content and by the elemental analyzer because of time constraints at the end of the expedition. Calcium carbonate contents range from 1.3 to $52 \mathrm{wt} \%$ in the sediments analyzed down to burial depths of $81 \mathrm{~m}$. Organic carbon ranges from 0.02 to $1.1 \mathrm{wt} \%$, with the highest value at $50 \mathrm{~m}$ (Fig. F35). $\mathrm{TOC}_{\mathrm{DIFF}} / \mathrm{TN}$ generally decreases with depth, with the exception of some of the high-carbonate samples in the 73-76 $\mathrm{m}$ depth interval.

\section{Microbiology}

Microbiological studies on sediment cores collected during DSDP, ODP, and IODP expeditions have demonstrated the presence of microbial communities in deeply buried marine sediments down to $>1600$ mbsf. The Canterbury Basin is a promising place to expand our knowledge of the deep biosphere in a complex setting, representing the history of life under a variety of environmental constraints. The basin is heavily influenced by the input of terrestrial organic matter and is therefore an excellent end-member environment to complement marine settings that have been studied during previous drilling expeditions.

The Expedition 317 shipboard microbiology program included collecting samples for onshore microbiological investigations, assessing the degree of seawater contamination of microbiological sediment samples, and testing a new cell-counting technique. Three sites were sampled for microbiology investigations (Sites U1351, U1352, and U1353). Eleven whole-round samples between $1630 \mathrm{~m}$ and the bottom of Hole U1352C at $1927 \mathrm{~m}$ were taken for microbiological and organic geochemical characterization of in situ microbial communities. These samples will be studied in more detail onshore and could potentially extend the maximum known depth of habitable sediments.

A cell-counting technique recently developed by Morono et al. (2009) was also tested. The procedure proved to be highly efficient, and discriminative detection and enumeration of microbial cells in sediments using diluted (1\%) hydrofluoric acid was achieved at Site U1351. The greatest abundance of cells was found in the near-surface sample, which contained $1.08 \times 10^{8}$ cells $/ \mathrm{cm}^{3}$, and the sample containing the smallest number of cells $\left(1.34 \times 10^{5}\right.$ cells $\left./ \mathrm{cm}^{3}\right)$ was found at $930.9 \mathrm{~m}$. Generally, the total number of cells decreased 
rapidly with depth in the uppermost $4 \mathrm{~m}$ of sediment. This depth profile follows a trend observed at ODP sites, but the absolute number of prokaryotes is lower than the averages for all previously examined sites, particularly below $4 \mathrm{~m}$.

Contamination tests were performed on board using particulate tracers, providing confirmation that uncontaminated samples can be recovered and there is no difference in contamination produced by the three types of coring (advanced piston corer [APC], $\mathrm{XCB}$, and RCB). Nevertheless, the dispersion of these tracers was found to not be homogeneous along the core liner, and microsphere concentrations were found to be diluted during RCB coring.

\section{Preliminary scientific assessment}

Expedition 317 marked a new direction for IODP by incorporating (1) drilling in shallow water on the continental shelf and (2) unusually deep penetrations. Expedition 317 set records for the shallowest water depth for a site drilled for scientific purposes and the deepest hole drilled on a continental shelf by the JOIDES Resolution, as well as the deepest sediment site and deepest site drilled in a single expedition in the history of scientific ocean drilling.

Only Leg 174A (New Jersey margin) previously attempted shelf drilling using the JOIDES Resolution. Experience gained during Leg 174A, where unconsolidated sands caused hole collapse during coring, suggested that similar problems might be encountered during Expedition 317 and penetrations might fall far short of target depths.

However, penetration during Expedition 317 exceeded all expectations. Drilling of Canterbury Basin sediments went smoothly even at the shallowest water sites (including Site U1354 in only $85 \mathrm{~m}$ water depth) and reached $1030 \mathrm{~m}$ in Hole U1351B on the outer shelf (122 m water depth). The performance of the drillers and the level of cooperation and support from the operations staff were superb. There was no hesitation in taking on new challenges.

Recovery was highly variable and, indeed, poor within long intervals of unconsolidated sediment, particularly at shelf Sites U1351 and U1353 during XCB coring (Fig. F17). This may be unavoidable with existing IODP coring technology. It would be very useful to develop new coring methods, if possible, for future operations in such lithologies. Percussive or vibracoring tools could provide solutions, although it will be important to maintain a reasonable rate of penetration in order to core thick sections equivalent to those targeted during Expedition 317. On the other hand, XCB coring was effective in the uppermost $250 \mathrm{~m}$ at shelf site Site U1354. A different recovery problem was encountered at slope site Hole $\mathrm{U} 1352 \mathrm{C}$, where RCB cores of solid rock with very low recovery (1\%-2\%) were occasionally interspersed with cores having $100 \%$ recovery, for reasons not fully understood (it was speculated that heavy rock cores may have fallen out of the core barrels). A correlation between rate of recovery and degree of sediment lithification was noted, with XCB drilling failing to recover lithified sediments, and RCB drilling failing to recover unlithified sediments. However, we believe that recovery was sufficient to achieve most of the expedition's objectives, particularly in providing ground truth at the scale of seismic resolution ( $\sim 5 \mathrm{~m}$ vertically).

Drilling in shallow water requires good weather (low heave and wind speeds that can be managed by the dynamic positioning system). In this we were extremely fortunate. Although it was often windy, only two delays were caused by weather. One was relatively minor because it occurred when the ship was about to move from slope Site U1352 to landward shelf Site U1353. The swell was considered too high for shelf operations, so we used the opportunity to duplicate the uppermost $127 \mathrm{~m}$ at Site U1352 by drilling Hole U1352D while we waited for conditions to improve. This occupied $<24 \mathrm{~h}$. The second delay was more serious and occurred at the final site (shelf Site U1354). The wind became too strong to maintain position over the hole in such shallow water $(113 \mathrm{~m})$, and operations in Hole U1354B were shut down after $73.6 \mathrm{~m}$ of APC coring. In this case we could only wait for weather conditions to improve, given the short time remaining for the expedition and the need to resume operations at Site U1354; however, once again the delay was $<24 \mathrm{~h}$. That the operational plan was impacted by $<2$ days in $>6$ weeks of operations, much of it in shallow water and in a region of unstable weather patterns, is remarkably fortunate and a tribute to the abilities of the dynamic positioning operators and drillers.

The upper sections $(\sim 500 \mathrm{~m})$ of most of the boreholes contained coarse-grained, unlithified material that proved highly unstable. This made wireline logging challenging, even in one instance when a dedicated logging hole was drilled (Hole U1351C). However, the logging personnel worked hard to achieve success and were always prepared to commit the tools to these unstable holes. Strategies were refined to manage the difficult conditions, including using a special tool combination at the final site.

It was possible to keep the holes clear of collapsing sand and shell hash during drilling while rotation and circulation were maintained, but, when these were stopped during logging, unconsolidated mate- 
rial flowed into the hole, forming bridges. In Hole U1351C this situation trapped the triple combination (triple combo) tool string, which was rescued using the drill pipe in a $36 \mathrm{~h}$ operation. In addition, the Formation MicroScanner (FMS)-sonic tool string could not be pulled into the drill pipe in Hole U1353C because the centralizers were jammed by debris. The tool was retrieved by tripping the pipe as the hole collapsed around it.

In spite of these difficulties, valuable logs were obtained, particularly at Site U1351, where the triple combo tool string reached the bottom of Hole $\mathrm{U} 1351 \mathrm{~B}$ at $1030 \mathrm{~m}$ WSF during the first run; in Hole U1353C, where a triple combo run was also completed in a dedicated logging hole to $\sim 530 \mathrm{~m}$ WSF; and at Site U1354, where a special tool string (gamma ray/sonic/resistivity) reached total depth at $380 \mathrm{~m}$ WSF. The caliper was at maximum extent over long intervals in all holes in which a caliper was run, implying significant wash-out.

The limited success at Site U1352, where logging was not possible below $\sim 500 \mathrm{~m}$ WSF in the $1927 \mathrm{~m}$ deep Hole U1352C, was surprising given that the sediments at this slope site were more fine grained than at the shelf sites. However, the amount of time (2 weeks) that Hole U1352C was open prior to logging probably caused significant deterioration of the hole, which may have played a part. The varying success at different sites may also have been related to the use of varying amounts/weights of mud during logging at different sites. A degree of mud rationing was required because of the heavy use of mud while coring in unstable lithologies and in deep holes with enlarged diameters.

Sonic and vertical seismic profile (VSP) data were especially important to expedition objectives for seismic correlation. However, although complete runs with the triple combo tool string were made to total depth in Holes U1351C and U1353C, the holes did not stay open long enough to complete a run with the second FMS-sonic tool string, let alone the third run required for the VSP. Therefore, FMS-sonic runs were not completed to total depth $(<500 \mathrm{~m}$ WSF in Holes U1351B and U1352B and $230 \mathrm{~m}$ WSF in Hole U1353C). It was for this reason that a modified string was used, with success, in Hole U1354C to total depth at $\sim 380 \mathrm{~m}$ WSF. No VSPs were conducted. Even if the holes had stayed open long enough for a VSP, wash-out made the holes too wide for the tool to make contact with the formation.

The sonic log from Hole U1351B requires postcruise processing, but the sonic log from Hole U1352B was used to generate a traveltime/depth conversion. The resultant velocities proved to be anomalously lower than the precruise-predicted function, which is itself evidently too low, at least for traveltimes corresponding to the deepest penetrations. Results from Hole U1353C may be more representative. The sonic $\log$ to $\sim 230 \mathrm{~m}$ WSF yielded an excellent synthetic seismogram and estimated depths to seismic sequence boundaries within the logged interval (U13$\mathrm{U10}$ ) that were $5-10 \mathrm{~m}$ deeper than predicted precruise. The sonic log from Hole U1354C was acquired late in the expedition and was not assessed while at sea.

Although the logs obtained will be extremely valuable, the limited depths reached by sonic logs, the lack of VSPs, and poor hole conditions limit our ability to provide an improved traveltime/depth conversion for seismic correlation throughout the full extent of the drilled interval. In a sense, wireline logging was a victim of Expedition 317's success in achieving deep penetrations. However, the relative ease of drilling indicates that logging-while-drilling (LWD) would be ideal for Canterbury Basin sites. Use of LWD was discussed before the expedition. However, the level of drilling difficulty and the associated risks to LWD equipment were anticipated to be more severe than turned out to be the case. Coupled with the cost of LWD operations at a time of financial constraint, this led to the decision not to employ LWD during Expedition 317. We hope that we will be able to return with LWD in the future.

\section{Site summaries}

\section{Site U1351}

\section{Background Hole U1351A}

Position: $44^{\circ} 53.0307^{\prime} \mathrm{S}, 171^{\circ} 50.4037^{\prime} \mathrm{E}$

Start hole: 0931 h, 18 November 2009

End hole: 2330 h, 18 November 2009

Time on hole (d): 0.58

Seafloor (drill pipe measurement from rig floor, $\mathrm{m}$ DRF): 133.3 (APC mudline)

Distance between rig floor and sea level $(\mathrm{m}): 11.0$

Water depth (drill pipe measurement from sea level, m): 122.3

Total depth (drill pipe measurement from rig floor, m DRF): 161.3

Total penetration (m DSF): 28.0

Total length of cored section $(\mathrm{m}): 28.0$

Total core recovered $(\mathrm{m}): 27.3$

Core recovery (\%): 98

Total number of cores: 6

\section{Hole U1351B}

Position: $44^{\circ} 53.0422^{\prime} \mathrm{S}, 171^{\circ} 50.4065^{\prime} \mathrm{E}$

Start hole: 2330 h, 19 November 2009 
End hole: 1800 h, 25 November 2009

Time on hole (d): 6.77

Seafloor (drill pipe measurement from rig floor, $\mathrm{m}$ DRF): 132.7 (APC mudline)

Distance between rig floor and sea level (m): 11.0

Water depth (drill pipe measurement from sea level, $\mathrm{m}): 121.7$

Total depth (drill pipe measurement from rig floor, m DRF): 1163.3

Total penetration (m DSF): 1030.6

Total length of cored section (m): 1030.6

Total core recovered $(\mathrm{m}): 304.5$

Core recovery (\%): 30

Total number of cores: 116

\section{Hole U1351C}

Position: $44^{\circ} 53.0572^{\prime} \mathrm{S}, 171^{\circ} 50.4057^{\prime} \mathrm{E}$

Start hole: 1800 h, 25 November 2009

End hole: 0200 h, 30 November 2009

Time on hole (d): 4.33

Seafloor (drill pipe measurement from rig floor, $\mathrm{m}$ DRF): 132.7 (by proxy, Hole U1351B)

Distance between rig floor and sea level (m): 11.0

Water depth (drill pipe measurement from sea level, m): 121.7

Total depth (drill pipe measurement from rig floor, m DRF): 1100.0

Total penetration (m DSF): 967.3

Total length of cored section $(\mathrm{m}): 0$

Total core recovered (m): 0

Core recovery (\%): 0

Total number of cores: 0

Site U1351 is located on the outer shelf and is the most basinward shelf site of the Canterbury Basin drilling transect. Seismic sequence boundaries U6U19 were penetrated at Site U1351. Lower Plioceneupper Miocene sequence boundaries (below U9) feature smooth onlapped paleoshelves and rounded clinoform breaks, or rollovers, with sigmoid internal reflection geometries. In contrast, upper PliocenePleistocene sequence boundaries (above U9) display eroded and incised downlapped paleoshelves and more pronounced breaks with oblique reflection geometries. U8-U19 were penetrated on their paleoshelves, whereas U6 and U7 were penetrated on their paleoslopes.

\section{Lithostratigraphy}

Stratigraphic changes at Site U1351 on the Canterbury margin are fairly gradual, reflecting progressive differences in sedimentary styles. Two lithologic units were differentiated based on transitional sedimentary facies. Unit I $(0-262 \mathrm{~m})$ is heterolithic, mainly dark gray to greenish gray or olive-gray in color, and is composed of mud and sandy mud with lesser shell hash, sand, and muddy sand. In contrast, Unit II (262-1024 m) is composed of mainly dark greenish gray to greenish black sandy mud (sandy mudstone) and muddy sand (muddy sandstone) with lesser sand (sandstone) and shell hash (limestone).

Unit I lithologies can be bounded by abrupt to gradational bedding planes, including distinct unconformities, and are locally bioturbated (ichnofabric index of 1-5). Fining- and coarsening-upward beds, lamination, convolute bedding, and carbonate concretions are rare. The diverse assemblage of bioclasts/ macrofossils is locally concentrated (shell hash) but is generally dispersed in the core and becomes less common with depth. Coarse shelly beds on the boundaries are overlain by fining-upward sandy mud and are followed by coarsening-upward lithologies. The arrangement of lithologies in Unit I is characteristic of eustatically influenced shelf successions. Tentatively, eight candidate surfaces (U1351-S1 to U1351-S8) were identified. These surfaces are all within the uppermost $250 \mathrm{~m}$ and generally have sharp basal contacts, are commonly bioturbated, and separate coarse lithologies from underlying muds.

Unit II is generally structureless, becoming more lithified with depth owing to carbonate cementation, as expressed in short pieces of cemented sandy mudstone recovered in the XCB core catcher. Recovery in Unit II was poor, but contrasts across lithologic boundaries appear more gradational downcore (from shelly to sandy to calcareous muds). Unit II comprises mainly dark greenish gray to greenish black sandy mud with an ichnofabric index of 1-3. Mineralogy suggests southerly schist rather than more local graywacke provenance, perhaps reinforcing the importance of northeastward-flowing currents during deposition. Alternatively, the schist detritus may be recycled from more local, uplifted, and eroded units onshore. The uppermost part of Unit II represents the transition from a shelf to slope environment. Below $\sim 300 \mathrm{~m}$ the sediments indicate deposition in an upper slope environment, with some intervals possibly influenced by drift deposition.

\section{Biostratigraphy}

The biostratigraphy of Site U1351 was based on shipboard study of calcareous nannofossils, diatoms, and planktonic and benthic foraminifers in core catcher samples from Holes U1351A and U1351B. Additional calcareous nannofossil samples were taken from within selected cores to address specific age and paleoenvironmental questions. All microfossil groups were present throughout the cored Holocene to upper Miocene section, except for diatoms, which were present in only a few samples. 
The Holocene to Pleistocene section between Cores 317-U1351B-1H and 18X (0-141.6 m) was primarily dated and divided using calcareous nannofossils into Zones NN21 (Cores 1H through 5H), NN20 (Cores $6 \mathrm{H}$ through $10 \mathrm{H}$ ), and NN19 (Cores $11 \mathrm{H}$ through 18X). Benthic foraminifers suggested that water depths were variable throughout the Pleistocene but generally deepened downcore, from inner-middle shelf depths to middle-outer shelf depths. The Pliocene section between Cores 317-U1351B-19X and 94X (151.2-822.3 m) was primarily dated with calcareous nannofossils in the upper part and with planktonic foraminifers in the lower part. Reworked calcareous nannofossils of Miocene age occurred throughout the lower part of the Pliocene, which was close to where planktonic foraminifers indicated a change to deposition on the slope and where the first consistently outer shelf to uppermost bathyal water depths were recorded, the upper part of the Pliocene being shallower. The Miocene section between Cores 317-U1351B-95X and 116X (831.8$1030.6 \mathrm{~m}$ ) was primarily dated with planktonic foraminifers. A major hiatus was identified between Sample 317-U1351B-113X-CC and Core 114X in the lowermost Miocene and was provisionally correlated with U5 in the seismic interpretation. Planktonic foraminifers and calcareous nannofossils suggested a hiatus of at least 3.4 m.y. Outer shelf to uppermost bathyal water depths persisted throughout the cored Miocene section, although planktonic foraminiferal abundances were consistent with deposition on the slope. The age at the bottom of Hole U1351B was late Miocene (10.60-10.91 Ma).

\section{Paleomagnetism}

Natural remanent magnetization (NRM) was measured on all but the most heavily disturbed cores. Intensities generally range from $10^{-2}$ to $10^{-4} \mathrm{~A} / \mathrm{m}$, with some higher intensity zones, particularly at the tops of cores, attributed to cave-in. NRM orientations tend to show steep $\left(\sim 80^{\circ}\right)$ positive inclinations and declinations clustered in the northern hemisphere. Alternating-field (AF) demagnetization was applied at 10 and $20 \mathrm{mT}$ steps and removed $\sim 30 \%$ of the NRM. Where magnetic core barrels had been used (in XCB coring from $94.7 \mathrm{~m}$ drilling depth below seafloor [DSF]), orientations changed very little with demagnetization. In contrast, where nonmagnetic core barrels were used with APC coring at shallower depths, NRM orientations did change with demagnetization. In the uppermost $65 \mathrm{~m}$ of Hole U1351B, inclinations after $20 \mathrm{mT}$ were negative (approximately $-70^{\circ}$ ), suggesting a normal characteristic component. Between 65 and $94 \mathrm{~m}$, core recovery decreased, and when material was available, inclinations shallowed with demagnetization but remained positive, suggesting that the first polarity change occurs between 65.9 and $69.7 \mathrm{~m}$. Poor core recovery and a strong drilling overprint at greater depths limited further magnetostratigraphic interpretations.

\section{Physical properties}

Systematic whole-round and/or section-half measurements of magnetic susceptibility, NGR, gamma ray attenuation (GRA) bulk density, and colorimetry revealed patterns of sedimentation characterized by well-defined cyclicity in the uppermost $180 \mathrm{~m}$. At greater depths these patterns seem to be missing, but this may be the result of poor core recovery. Downhole logging suggests that lower amplitude cycles may persist to at least $400 \mathrm{~m}$. Automated vane shear (AVS) and fall cone penetrometer (FCP) sediment strength tests and moisture and density (MAD) analyses reveal interesting trends. The observed shear strength generally reflects the cyclicity seen in other parameters in the uppermost $250 \mathrm{~m}$. Additionally, abrupt changes or offsets in both magnetic susceptibility and shear strength suggest the presence of unconformities. A gradual increase in bulk density with depth was matched by a similarly subtle decrease in porosity from an average of $\sim 45 \%$ at the surface to $\sim 37 \%$ at $1000 \mathrm{~m}$. Thermal conductivity variations seemed to follow these trends.

\section{Geochemistry}

High-frequency sampling established the midpoint of the SMT at $16 \mathrm{~m}$, based on the dissolved sulfate and methane gradients. The maximum alkalinity at the SMT was $10 \mathrm{mM}$, with marked cation depletions of $17 \mathrm{mM}$ for $\mathrm{Mg}^{2+}$ and $5 \mathrm{mM}$ for $\mathrm{Ca}^{2+}$. The apparent levels of carbon oxidized and low levels of ammonium and phosphate generated suggest that sulfate reduction is fueled primarily by AOM. The initial gas present beneath the SMT contains ethane at relatively high levels $\left(C_{1} / C_{2}=500-800\right)$, but absolute gas contents were low $\left(3,000-20,000\right.$ ppm $C_{1}$ in headspace or 1-6 $\mathrm{mM}$ in pore space). This suggests preferential loss of methane due to AOM (possibly when the shelf at Site U1351 was emergent) or gas loss from sands during core recovery and sampling. The gas did not show any major deviations from established trends at greater depths to $1000 \mathrm{~m}$. The pore waters in the uppermost $250 \mathrm{~m}$ have moderately elevated $\mathrm{Cl}^{-}$and $\mathrm{Na}^{+}\left(\sim 10 \%\right.$ greater than seawater). $\mathrm{Ca}^{2+}$ increases from 16 to $40 \mathrm{mM}$, whereas $\mathrm{Mg}^{2+}$ decreases from 30 to $20 \mathrm{mM}$ over the interval between 200 and $250 \mathrm{~m}$. There are also marked differences in the sediment geochemistry, with higher carbonate, higher nitrogen, and lower sulfur above $200 \mathrm{~m}$. Organic carbon contents range from $<0.1$ to $1.5 \mathrm{wt} \%$, with more 
frequent higher values in the uppermost $200 \mathrm{~m}$. Pyrolysis characterization suggests that the organic matter is dominated by degraded higher plant debris.

\section{Heat flow}

Only one out of five temperature measurements taken at this site was of acceptable quality based on conductive cooling curves over $>300 \mathrm{~s}$. Using all five temperature measurements yields a poorly fit geothermal gradient of $14.1^{\circ} \mathrm{C} / \mathrm{km}$, much lower than the $40^{\circ}-50^{\circ} \mathrm{C} / \mathrm{km}$ obtained at the Clipper well (Reyes, 2007) and almost certainly in error. Thermal conductivity measured in the laboratory $(0.962-2.233 \mathrm{~W} /[\mathrm{m} \cdot \mathrm{K}])$ was corrected to in situ conditions (0.959-2.215 $\mathrm{W} /[\mathrm{m} \cdot \mathrm{K}])$. The resulting values increase linearly with depth. Use of a Bullard plot yields a heat flow of $20.1 \mathrm{~mW} / \mathrm{m}^{2}$. However, as with the estimated geothermal gradient, heat flow values are suspect because of insufficient reliable temperature measurements.

\section{Downhole logging}

Downhole logging took place in Holes U1351B and U1351C. Two tool strings were deployed in Hole U1351B: (1) the triple combo tool string, which measures gamma radiation, bulk density, porosity, and electrical resistivity, was run from the seafloor to 1032 m WSF; (2) the FMS-sonic tool string, which measures electrical resistivity images and sonic velocities, could not reach the total depth of the hole and acquired data from 74 to $488 \mathrm{~m}$ WSF. In Hole U1351C, only the triple combo tool string was deployed, recording gamma radiation and resistivity during its descent between the seafloor and $801 \mathrm{~m}$ WSF. The tool was trapped by hole collapse, preventing logging of the deeper section of Hole U1351C. The complete tool string was later recovered after a $36 \mathrm{~h}$ recovery effort.

Three logging units were identified in the logs. Logging Unit 1 (83-260 m WSF) is characterized by relatively high amplitude variations in gamma ray values, which increase overall with depth. In this unit, gamma ray minima associated with high resistivity and sonic velocities are consistent with sand layers alternating with clay. Logging Unit 2 (260-510 m WSF) is defined by low-amplitude variability in all logs and trends of decreasing gamma radiation and resistivity. Three distinct intervals of uphole-increasing gamma radiation within this unit suggest finingupward transgressive sequences. Caliper readings consistently higher than 19.5 inches in Units 1 and 2 show that the formation has little cohesion. The top of Logging Unit 3 (510-1032 m WSF) is defined by significant downhole increases in gamma radia- tion, density, and resistivity, which remain variable with no distinct trends in this unit. The borehole diameter was slightly smaller (12-18 inches) but was irregular, suggesting a change to more cohesive sediments.

\section{Site U1352}

\section{Background \\ Hole U1352A}

Position: $44^{\circ} 56.2440^{\prime} \mathrm{S}, 172^{\circ} 1.3615^{\prime} \mathrm{E}$

Start hole: 1145 h, 30 November 2009

End hole: 1530 h, 30 November 2009

Time on hole (d): 0.16

Seafloor (drill pipe measurement from rig floor, $\mathrm{m}$ DRF): 354.8 (APC mudline)

Distance between rig floor and sea level (m): 11.0

Water depth (drill pipe measurement from sea level, $\mathrm{m}): 343.8$

Total depth (drill pipe measurement from rig floor, m DRF): 397.0

Total penetration (m DSF): 42.2

Total length of cored section (m): 42.2

Total core recovered $(\mathrm{m}): 43.92$

Core recovery (\%): 104

Total number of cores: 5

\section{Hole U1352B}

Position: $44^{\circ} 56.2558^{\prime} \mathrm{S}, 172^{\circ} 1.3630^{\prime} \mathrm{E}$

Start hole: 1530 h, 30 November 2009

End hole: 1615 h, 5 December 2009

Time on hole (d): 5.03

Seafloor (drill pipe measurement from rig floor, $\mathrm{m}$ DRF): 354.6

Distance between rig floor and sea level (m): 11.0

Water depth (drill pipe measurement from sea level, m): 343.6

Total depth (drill pipe measurement from rig floor, m DRF): 1185.5

Total penetration (m DSF): 830.9

Total length of cored section (m): 830.9

Total core recovered $(\mathrm{m}): 613.87$

Core recovery (\%): 74

Total number of cores: 94

\section{Hole U1352C}

Position: $44^{\circ} 56.2662^{\prime} \mathrm{S}, 172^{\circ} 1.3630^{\prime} \mathrm{E}$

Start hole: 2015 h, 5 December 2009

End hole: 2200 h, 20 December 2009

Time on hole (d): 15.07

Seafloor (drill pipe measurement from rig floor, $\mathrm{m}$ DRF): 354.5 (tagging seafloor)

Distance between rig floor and sea level (m): 11.0

Water depth (drill pipe measurement from sea level, m): 343.5 
Total depth (drill pipe measurement from rig floor, m DRF): 2282.0

Total penetration (m DSF): 1927.5

Total length of cored section (m): 1296.4

Total core recovered $(\mathrm{m}): 655.02$

Core recovery (\%): 51

Total number of cores: 146

\section{Hole U1352D}

Position: $44^{\circ} 56.2326^{\prime} \mathrm{S}, 172^{\circ} 1.3611^{\prime} \mathrm{E}$

Start hole: 0615 h, 21 December 2009

End hole: 2100 h, 21 December 2009

Time on hole (d): 0.61

Seafloor (drill pipe measurement from rig floor, $\mathrm{m}$ DRF): 345.2 (APC mudline)

Distance between rig floor and sea level (m): 11.0

Water depth (drill pipe measurement from sea level, $\mathrm{m}): 344.2$

Total depth (drill pipe measurement from rig floor, m DRF): 472.2

Total penetration (m DSF): 127.0

Total length of cored section $(\mathrm{m}): 127.0$

Total core recovered $(\mathrm{m}): 130.84$

Core recovery (\%): 103

Total number of cores: 14

Site U1352 is located on the upper slope within the Canterbury Bight and is the most basinward site of the Canterbury Basin drilling transect. Seismic sequence boundaries U6-U19 were penetrated at Site U1352, where sediments are finer grained and pelagic microfossils are more abundant than at shelf sites, providing good age control for sequences drilled on the shelf.

An additional target, requiring deep penetration, was recovery of the early Oligocene Marshall Paraconformity. The paraconformity is presumed to record intensified current erosion or nondeposition at all water depths that accompanied the development of a partial Antarctic Circumpolar Current system following the opening of the seaway south of Tasmania. There are indications from Leg 181 drilling that the paraconformity developed in deep (bathyal) water 1-2 m.y. earlier than in shallow water. Dating the paraconformity in the offshore Canterbury Basin at Site U1352 tests this hypothesis by sampling it where paleowater depths were intermediate.

Because of time constraints, drilling into one of the large, elongate sediment drifts of the Canterbury Basin became a secondary contingency objective. However, it is likely that insights into sediment drift deposition and paleoceanography will be obtained from Site U1352 cores. Current reworking of sediments is evident at Site U1352, even though distinctive large-scale drift seismic geometries are absent.

\section{Lithostratigraphy}

Four holes were drilled at Site U1352, reaching a total depth of $1927 \mathrm{~m}$ and spanning the Holocene to late Eocene. This site contains a gradual lithologic transition between the Holocene and Miocene and a major unconformity between the early Miocene and early Oligocene at $1853 \mathrm{~m}$. The succession is divided into three lithologic units.

Unit I (0-711 m) spans the Holocene to middle Pliocene and contains predominantly mud-rich sediment consisting of calcareous sandy mud, interbedded sandy mud and clay, interbedded sand and mud, massive sand, mottled sandy mud, homogeneous mud, shelly mud, and marl. The ichnofabric index is $1-5$. Unit I is divided into three subunits. Subunit IA $(0-98 \mathrm{~m})$ is dominated by interbedded mud, sand, and clay lithologies, with frequent greenish gray sharp-based muddy sand or sandy mud beds. Subunit IB (98-447 m) contains more homogeneous mud and less frequent sharp-based greenish gray muddy sand or sandy mud beds. Subunit IC (447$711 \mathrm{~m}$ ) represents a transition between the muddominated lithologies of Unit I and the calcareous lithologies of Unit II. This gradual transition reflects a progressive change in water depth to deeper slope depositional environments.

Unit II (711-1853 m) spans the middle Pliocene through lower Miocene and contains hemipelagic to pelagic sediment consisting of calcareous sandy mud, sandy marls, chalk, sandy marlstone, and sandy limestone with minor amounts of calcareous mudstone and sandstone. The ichnofabric index is $1-5$. The unit is divided into three subunits. Subunit IIA (711-1189 m) ranges from homogeneous marl (in Hole U1352B) to bioturbated marlstone (in Hole U1352C). Occasional mudstone, muddy sandstone, and chalk lithologies also occur. Subunit IIB (1189$1694 \mathrm{~m}$ ) contains abundant dark-colored mudstone beds in the upper part and more frequent occurrences of current bedding, especially toward the base of the unit. The frequency of mudstone bed occurrence decreases below $1392 \mathrm{~m}$, in concert with other changes in mineralogy and an unconformity detected by biostratigraphy. Packages of recumbent and isoclinal folds, tilted beds, contorted strata, and fluid escape features are present both above and below this unconformity. Subunit IIC (1694-1853 m) contains a gradual progression from marlstone to limestone, with frequent glauconitic laminae and beds.

A $~ 12$ m.y. unconformity occurs at the base of Unit II, with an abrupt change into lithologic Unit III (1853-1924 m [total depth]) consisting of hemipelagic to pelagic foraminifer-bearing nannofossil limestone of early Oligocene to late Eocene age with an 
ichnofabric index of 1-5. Except for minor abundances of quartz and clay, Unit III lacks siliciclastic components. This unit is correlative to the onshore Amuri Limestone.

Site U1352 represents an upper Eocene to lower Oligocene and nearly complete Neogene continental slope sedimentary record dominated by pelagic to hemipelagic sedimentation with minor traction and gravity flow sediments. The sediments were deposited along a passive continental margin characterized by large volumes of sediment from a tectonically and climatically evolving hinterland. The site represents a unique downhole record from unlithified sediments to lithified carbonates at depth. The gradual downhole transition in lithofacies from more siliciclastic-rich Pleistocene-Holocene muddy facies into pelagic limestones and glauconitic marlstones and marls appears to reflect the downhole transition, seen on seismic profiles, from an upper slope location on a clinoformal margin with a sharp shelf-slope break in the Pleistocene-Holocene toward a toe-of-slope location on a more ramplike margin in the Miocene. The lower carbonate content in the upper part of this interval may be linked to higher terrigenous supply, possibly related to the uplift of the Southern Alps and/or Neogene climate change.

\section{Biostratigraphy}

Site U1352 recovered a Holocene-upper Eocene succession. Fifty-five bioevents were recognized and used to provide a detailed biostratigraphic framework. Calcareous nannofossils were the primary dating tool in the Pleistocene, whereas planktonic foraminifers provided robust age control in the Pliocene-middle Miocene section. Both fossil groups were integral for biostratigraphic assessment of the lower Miocene-upper Eocene succession. Diatoms were sparse but provided two useful Pleistocene datums. Analysis of benthic foraminifer assemblages yielded detailed estimates of paleowater depths throughout the succession.

A $~ 500 \mathrm{~m}$ thick progradational Holocene-Pleistocene section was recovered, and 16 bioevents were distinguished. The Pliocene/Pleistocene boundary was constrained between 492 and $525 \mathrm{~m}$ and is potentially unconformable. Sediments below the boundary were dated at 2.45-3.04 Ma, suggesting that most, if not all, of the upper Pliocene was missing. Pleistocene nannofossil abundances fluctuated dramatically across predicted seismic sequence boundaries (most notably from 0.8 Ma to recent). Similar fluctuations in planktonic foraminifer abundances were also noted near seismic surfaces interpreted as sequence boundaries.
The progradational Pliocene interval was also thick

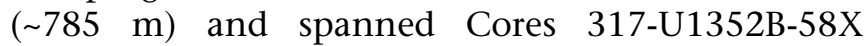
through 73R $(500-1285 \mathrm{~m})$. As at Site U1351, all standard nannofossil zonal markers (except Reticulofenestra pseudoumbilicus) were absent. The Miocene/Pliocene boundary was identified between 1266 and $1284 \mathrm{~m}$ and is conformable, although potentially condensed toward the base of the Pliocene.

Twenty-six foraminifer and nannofossil datums were observed within the cored Miocene succession $(1275-1851 \mathrm{~m})$. The Miocene interval contained three biostratigraphically defined unconformities: a lower upper Miocene unconformity between Cores 317-U1352C-90R and 91R (1395-1410 m), an unconformity within the upper to middle Miocene transition between Cores 101R and 102R (1487$1497 \mathrm{~m}$ ), and the Marshall Paraconformity between Cores 139R and 140R (1848-1853 m). The latter separated lower Miocene sediments ( 18-19 Ma) from underlying lower Oligocene sediments (30.1-32.0 Ma), with $\sim 12$ m.y. absent.

The Oligocene and Eocene intervals were relatively thin (1851-1910 and 1910-1924 m, respectively). Microfossil preservation was generally poor in Oligocene sediments and moderate in the Eocene. This boundary was recognized between Cores 317U1352C-146R and 147R (1903-1917 m) and was unconformable, with $\sim 2.3$ m.y. missing. The bottomhole age was constrained between 35.2 and $36.0 \mathrm{Ma}$ in Core 148R (1924 m).

Pleistocene and Pliocene sediments were dominated by inner to outer shelf benthic foraminiferal taxa, although the rare but persistent presence of bathyal marker species suggested that the shallower shelfal taxa were possibly reworked. Paleodepths generally increased downhole to lower bathyal depths in the lower part of the cored succession. Middle to deep bathyal taxa occurred in lower Pliocene and older sediments, which is consistent with the generally increasing downhole abundance of planktonic foraminifers through the progradational foreset sequence into the bottom sets and basin floor facies and coincides with the change from suboceanic to fully oceanic conditions.

\section{Paleomagnetism}

NRM was measured on all but the most disturbed cores from all four holes at Site U1352. Intensity ranged from $10^{-2}$ to $10^{-3} \mathrm{~A} / \mathrm{m}$ in the upper half of the drilled interval and decreased to $10^{-4} \mathrm{~A} / \mathrm{m}$ in the lower half of the record (consistent with an increase in carbonate). One AF demagnetization step at peak fields of $20 \mathrm{mT}$ was routinely applied. Where nonmagnetic core barrels were used with APC coring 
(the uppermost 27 cores in Hole U1352B [to $246 \mathrm{~m}$ ]), inclinations after $20 \mathrm{mT}$ demagnetization are well grouped around $-60.1^{\circ}$. The uppermost 18 cores (to $166 \mathrm{~m}$ ) are azimuthally oriented and show a mean declination of $27.7^{\circ}$ after correction. These values are close to the orientation of the present-day magnetic field (inclination $-70^{\circ}$, declination $25^{\circ}$ ). The relatively shallower inclination of this component suggests that it may be a primary magnetization. The change to magnetic barrels occurred within the interval where the Brunhes/Matuyama boundary was anticipated (from biostratigraphic age determinations), and the boundary was not unambiguously identified at this site. A pervasive drilling overprint hampered further magnetostratigraphic interpretation.

Rock magnetic experiments and demagnetization of discrete specimens indicate that a low-coercivity mineral is the main magnetization carrier. Thermal demagnetization of NRM showed unblocking temperatures in the range of $320^{\circ}$ to $340^{\circ} \mathrm{C}$ and an increase in susceptibility at $\sim 400^{\circ} \mathrm{C}$, suggesting the presence of iron sulfides.

\section{Physical properties}

Core physical properties change with depth broadly, as anticipated, with decreasing overall trends in magnetic susceptibility and NGR and an increasing trend in bulk density obtained from GRA and MAD methods.

The uppermost $275 \mathrm{~m}$ exhibits regular cyclicity in magnetic susceptibility and NGR, similar to the NGR record at Site 1119 . For example, three peaks between 50 and $70 \mathrm{~m}$ in Hole U1352B correlate with peaks in Holes 1119B and 1119C (between 36 and 46 mbsf), which have been recognized as signals of MIS 5. Magnetic susceptibility, NGR, GRA bulk density, and color reflectance $b^{*}$ show unexplained but conspicuous negative peaks between 555 and $630 \mathrm{~m}$, followed positive peaks at $665 \mathrm{~m}$. Below the Marshall Paraconformity $(\sim 1853 \mathrm{~m})$, magnetic susceptibility switches to negative values, consistent with diamagnetic limestone.

Excellent $P$-wave velocity measurements were obtained using the $P$-wave caliper (PWC) method on discrete samples from cemented sediments in $\mathrm{RCB}$ cores from Hole U1352C. PWC values increase slightly below $1255 \mathrm{~m}$ (averaging 2500-3500 m/s) and increase strongly between 1500 and $1670 \mathrm{~m} \mathrm{(av-}$ eraging $\sim 3500-4000 \mathrm{~m} / \mathrm{s}$ ). Below $\sim 1795 \mathrm{~m} P$-wave velocity increases again to $5900 \mathrm{~m} / \mathrm{s}$, and an additional slight increase in $P$-wave velocity was observed below the Marshall Paraconformity. The unexpected high velocities below $1255 \mathrm{~m}$ may require a revision of the traveltime/depth conversion of seismic records.

Reflectance spectrometry measurements on split cores revealed clear trends in both reflectivity and color. Variations in color were observed to correlate with similar variations in magnetic susceptibility.

Results from MAD analyses revealed downhole trends in sediment compaction and lithification. Lithologic Subunit IA shows little downhole variability, but porosity begins to decrease and bulk density begins to increase in Subunit IB. Cementation begins at this level and increases downcore toward lithologic Subunit IIB, which is almost fully cemented. Grain density varies little with depth.

AVS and FCP sediment strength tests indicate that sediments range from very soft $\left(0-20 \mathrm{kN} / \mathrm{m}^{2}\right)$ to very stiff $\left(150-300 \mathrm{kN} / \mathrm{m}^{2}\right)$. Sediment strengths correlate well in very soft and soft sediments, but AVS tests appear to underestimate shear strength in firm to very stiff sediments. The pronounced cyclicity in shear strength seen at Site U1351 was not observed at Site U1352.

\section{Geochemistry}

The SMT occurs between 15 and $17 \mathrm{~m}$. The apparent level of carbon oxidized relative to sulfate reduced suggests that sulfate reduction is driven by both methane oxidation and organic matter oxidation. The initial gas below the SMT contains ethane (2 ppmv) with $\mathrm{C}_{1} / \mathrm{C}_{2}$ of $\sim 16,000$. Gas composition changes regularly with increasing depth, reaching $\mathrm{C}_{1} / \mathrm{C}_{2}$ of $\sim 60$ near the bottom of Hole U1352C at $1920 \mathrm{~m} . \mathrm{C}_{3}-\mathrm{C}_{5}$ hydrocarbon abundance also generally increases with depth. At an apparent unconformity near $1390 \mathrm{~m}$, gas content is very low (40 ppmv methane) and $\mathrm{C}_{1} / \mathrm{C}_{2}$ drops as low as 7 , mainly because of the near absence of methane. Below the unconformity the gas resumes the normal trend. The initial predominance of branched $\mathrm{C}_{4}$ and $\mathrm{C}_{5}$ alkanes in the gas decreases with depth. Below the unconformity the normal/(normal + iso) $\mathrm{C}_{4}$ and $\mathrm{C}_{5}$ ratios show a large and consistent decrease followed by an increase, which so far remains unexplained but most likely reflects the mixing of different gas generations.

Analyses of sediment samples distinguish the clayrich lithologic Unit I from the carbonate-dominated Unit II. Organic carbon content is generally low $(<0.6 \mathrm{wt} \%)$, with only a few samples having $>1 \mathrm{wt} \%$ TOC. The character of the organic matter changes from relatively labile volatile material in the shallower sediments to more stable proto-kerogen down- 
hole, with evidence for increasing thermal maturity at total depth. The organic matter appears to be mainly terrestrial plant in origin.

Interstitial water analyses were conducted to 1400 $\mathrm{m}$. Initial reductions in calcium and magnesium in the SMT are related to microbial processes (sulfate reduction and methanogenesis). Below $400 \mathrm{~m}$, calcium, magnesium, and strontium concentrations in interstitial water increase and alkalinity decreases, consistent with dissolution of carbonates and the poor preservation of microfossils. Potassium and sodium concentrations decrease markedly below $300 \mathrm{~m}$, possibly related to glauconite formation, whereas fluctuations in silica concentrations point to dissolution of siliceous fossils. Increasing boron concentrations below $200 \mathrm{~m}$ may reflect a diagenetic opal-A/opal-CT transition and microbial degradation of organic matter. A lithium increase below $500 \mathrm{~m}$ can be explained by dehydration reactions that remove lithium from clay interlayer exchange sites.

Eleven whole-round samples were taken between $1630 \mathrm{~m}$ and the bottom of Hole U1352C at $1927 \mathrm{~m}$ for microbiological and organic geochemical characterization of in situ microbial communities. Onshore investigation of these samples could potentially extend the maximum known depth of habitable sediments.

\section{Heat flow}

Four good-quality temperature measurements out of six measurement attempts in the depth interval from 94 to $313 \mathrm{~m}$ yielded a geothermal gradient of $46.2^{\circ} \mathrm{C} / \mathrm{km}$. Laboratory thermal conductivity measurements from 8 to $1920 \mathrm{~m}$, with a range of 0.849 $3.440 \mathrm{~W} /(\mathrm{m} \cdot \mathrm{K})$, reveal a trend of increasing thermal conductivity with depth except in the topmost 90 $\mathrm{m}$, where a decreasing trend was observed. Two individual trends were recognized: one for unlithified sediment from 90 to $800 \mathrm{~m}$ and another for hard rock from 600 to $1920 \mathrm{~m}$. Thermal conductivity shows positive and negative relationships with bulk density and porosity, respectively. Heat flow was calculated as $57.8 \mathrm{~mW} / \mathrm{m}^{2}$ within the depth interval where the geothermal gradient was established. Assuming steady-state heat flow, the temperature profile yields a bottom-hole temperature of $\sim 60^{\circ} \mathrm{C}$, but this would be higher if a constant geothermal gradient were assumed.

\section{Downhole logging}

Downhole logging at Site U1352 took place in Holes U1352B and U1352C. Two tool strings were deployed in Hole U1352B: (1) the triple combo tool string, which measures natural gamma ray, bulk den- sity, porosity, and electrical resistivity, was run from the seafloor to $487 \mathrm{~m}$ WSF, below which an obstruction prevented it from reaching total depth, and (2) the FMS-sonic tool string, which measures electrical resistivity images and sonic velocities, encountered the same blockage and acquired data from 82 to $442 \mathrm{~m}$ WSF. In Hole U1352C, hole conditions were unstable, and only a modified triple combo (without radioactive sources) tool string was deployed, recording gamma ray and resistivity between the seafloor and $207 \mathrm{~m}$ WSF. Below $207 \mathrm{~m}$ WSF the tool string encountered a blockage that prevented it from reaching total depth.

Two logging units were identified. Logging Unit 1 (82-250 m WSF) is characterized by relatively low amplitude variations in gamma radiation, resistivity, and acoustic velocities. A distinct uphole-increasing and then uphole-decreasing trend in gamma radiation is consistent with gamma ray logs at Site 1119 and may be associated with variations in clay content. Resistivity decreases with depth in this unit, whereas velocity increases with depth. Caliper measurements consistently higher than 19.5 inches indicate an enlarged borehole in this interval. Logging Unit 2 (250-487 m WSF) is defined by a change to higher amplitude variations in gamma radiation, resistivity, and acoustic velocities. Gamma radiation and velocity show increasing trends with depth, whereas resistivity varies around a relatively constant value. Sharp peaks in $P$-wave velocity associated with variations in density or lithology may correlate with significant seismic reflections in this unit. The borehole diameter is smaller but highly irregular (6-19.5 inches) and may reflect the appearance of more cohesive marls within the formation.

\section{Site U1353}

\section{Background Hole U1353A}

Position: $44^{\circ} 46.1079^{\prime} \mathrm{S}, 171^{\circ} 40.4368^{\prime} \mathrm{E}$

Start hole: 0230 h, 22 December 2009

End hole: 1115 h, 22 December 2009

Time on hole (d): 0.36

Seafloor (drill pipe measurement from rig floor, $\mathrm{m}$ DRF): 95.5 (APC mudline)

Distance between rig floor and sea level (m): 11.3

Water depth (drill pipe measurement from sea level, $\mathrm{m}): 84.2$

Total depth (drill pipe measurement from rig floor, m DRF): 151.5

Total penetration (m DSF): 56.0

Total length of cored section $(\mathrm{m}): 56.0$

Total core recovered $(\mathrm{m}): 56.38$

Core recovery (\%): 101

Total number of cores: 8 


\section{Hole U1353B}

Position: $44^{\circ} 46.1203^{\prime} \mathrm{S}, 171^{\circ} 40.4407^{\prime} \mathrm{E}$

Start hole: 1115 h, 22 December 2009

End hole: 2050 h, 26 December 2009

Time on hole (d): 4.40

Seafloor (drill pipe measurement from rig floor, $\mathrm{m}$ DRF): 96.0 (APC mudline)

Distance between rig floor and sea level (m): 11.3

Water depth (drill pipe measurement from sea level, $\mathrm{m}): 84.7$

Total depth (drill pipe measurement from rig floor, m DRF): 710.3

Total penetration (m DSF): 614.3

Total length of cored section $(\mathrm{m}): 614.3$

Total core recovered (m): 211.48

Core recovery (\%): 34

Total number of cores: 98

\section{Hole U1353C}

Position: $44^{\circ} 46.0982^{\prime} \mathrm{S}, 171^{\circ} 40.4380^{\prime} \mathrm{E}$

Start hole: 2050 h, 26 December 2009

End hole: 2100 h, 28 December 2009

Time on hole (d): 2.01

Seafloor (drill pipe measurement from rig floor, $\mathrm{m}$ DRF): 96.0 (by proxy, Hole U1353B)

Distance between rig floor and sea level (m): 11.3

Water depth (drill pipe measurement from sea level, $\mathrm{m}): 84.7$

Total depth (drill pipe measurement from rig floor, m DRF): 625.0

Total penetration (m DSF): 529.0

Total length of cored section (m): 0

Total core recovered (m): 0

Core recovery (\%): 0

Total number of cores: 0

Site U1353 is located on the middle shelf within the Canterbury Bight and is the most landward shelf site of the Canterbury Basin drilling transect. As a result, Site U1353 was considered the most challenging site, both because the water depth at the site $(85 \mathrm{~m})$ is the shallowest of all Expedition 317 sites and also because the lithologies at this inboard setting were likely to be particularly coarse grained.

Site U1353 penetrates a middle Miocene-Holocene section containing seismic sequence boundaries U5U19. All sequence boundaries were penetrated landward of their rollovers, or paleoshelf edges, with the goal of recovering proximal facies, yielding evidence of shallow-water deposition, and providing optimal paleowater depths from benthic foraminiferal biofacies. Cores from Site U1353 include upper Miocene to lower Pliocene sequence boundaries (below U10) that feature smooth onlapped paleoshelves and rounded rollovers with middle Pliocene to Pleistocene sequence boundaries (U10 and above), which display eroded and incised downlapped paleoshelves and more pronounced rollovers.

\section{Lithostratigraphy}

Site U1353 provides an excellent and unique sedimentary record of deposition through the HolocenePleistocene period of global sea level fluctuations. Hole U1353B also penetrated some of the older early Pleistocene-Miocene seismic reflectors in the offshore Canterbury Basin, which at this site are at relatively shallow subbottom depths of $<500 \mathrm{~m}$. Poor core recovery, however, hindered lithologic interpretation in deeper portions of the hole.

Cores recovered from Holes U1353A and U1353B show a downhole transition from a heterolithic upper section with abrupt contacts (Unit I) to a more featureless, mud-dominated section with depth (Unit II). These changes suggest a progressive and gradual change in sedimentary style as the margin evolved.

Unit I (Hole U1353B, 0-151 m) is characterized by its overall muddy character, the dominant lithology being a dark greenish gray homogeneous mud with a few percent very fine sand. Shells are either rare and scattered or locally concentrated in layers as thick as $15 \mathrm{~cm}$. Bioturbation is common, with ichnofabric indexes of 3-4. Subordinate lithologies include shelly mud to shell hash, micaceous well-sorted very fine sand, clay, and sandy marl.

The dominant lithology of Unit II (Hole U1353B, 151-614 m) consists of dark greenish gray, micaceous very fine sandy mud and mud, typically with shells. Both types of sediment are slightly to heavily bioturbated (ichnofabric indexes of 2-4). Sand and cemented intervals were recovered sporadically throughout the unit as minor lithologies.

Close similarities were noted between Site U1353 and Sites U1354 and U1351 (located 13 and $20 \mathrm{~km}$, respectively, to the southeast). Comparable Unit I and II subdivisions and constituent lithotypes were recognized at these sites, and potential lithologic expression of seismic unconformities can also be matched between the sites. Site U1353 was interpreted to represent a slightly more shoreline-proximal equivalent of Sites U1354 and U1351. Deposition is dominated by shelf processes, characterized during Unit I (Holocene-Pleistocene) by frequent sea level variations and preceded by inner to middle shelf depositional settings through Unit II (early Pleistocene-Miocene).

\section{Biostratigraphy}

Calcareous nannofossil, planktonic and benthic foraminifer, and diatom assemblages from Site U1353 
core catcher samples were used to create a shipboard biostratigraphic framework. Benthic foraminifers were also used to estimate paleowater depths. Diatoms were sparse to absent at this site.

Site U1353 contained a Holocene to Miocene succession. Thirteen biostratigraphic events were recognized, most of them in the Pleistocene. Pleistocene microfossil abundances were high, and assemblages exhibited good preservation, which allowed for robust age control, particularly with nannofossils. A hiatus was recognized within the middle-lower Pleistocene section between Samples 317-U1353B-12H-CC and 14X-CC $(80.12-80.77 \mathrm{~m})$, where $\sim 0.8 \mathrm{~m}$.y. was missing.

The Pliocene/Pleistocene boundary was biostratigraphically picked between Samples 317-U1353B$21 \mathrm{H}-\mathrm{CC}$ and $23 \mathrm{H}-\mathrm{CC}(121.16-135.71 \mathrm{~m})$ and is unconformable, missing most, if not all, of the upper Pliocene. Biostratigraphic analysis of Pliocene and Miocene sediments at this site was particularly problematic for all microfossil groups because of either low abundances and/or the absence of biostratigraphic markers. Below Sample 60H-CC (257.69 m), nannofossil abundances dropped sharply and remained low for the rest of the downhole succession. Samples below this level were nearly barren of planktonic foraminifers, but shelfal benthic foraminifers were present, albeit without reliable age-diagnostic markers.

Nevertheless, several important datums allowed for biostratigraphic constraint and critical correlation with Sites U1351 and U1352. The early/middle Pliocene boundary was distinguished on the basis of a nannofossil datum (3.7 Ma) between Samples 317U1353B-27H-CC and 28H-1, 124 cm (149.68$150.64 \mathrm{~m}$ ). In combination with a planktonic foraminifer datum $(<4.3 \mathrm{Ma})$ it constrained the interval from 150.64 to $256.04 \mathrm{~m}$ to the lower Pliocene between 3.7 and 4.3 Ma. The Miocene/Pliocene boundary could not be picked biostratigraphically.

Although Site U1353 yielded no biostratigraphic evidence for upper Miocene sediments, the extrapolation of correlative seismic reflectors from outermost shelf Site U1351 supported the presence of an upper Miocene interval at Site U1353. A nannofossil marker constrained between Samples 317-U1353B88X-CC and 89X-CC (510.52-518.66 m) was dated older than $12.03 \mathrm{Ma}$, indicating a substantial hiatus above this interval, although the amount of time missing is unknown. Samples below 90X-CC were barren of calcareous nannofossils and planktonic foraminifers, except for the bottommost core catcher (98X-CC [604.60 m]), which contained sparse nannofossils with an assemblage age of middle to early Miocene.
Paleowater depths derived from benthic foraminifers ranged from subtidal to outer shelf environments throughout the Holocene to Miocene section but were no deeper than outer shelf. Pleistocene paleowater depths fluctuated between subtidal and middle shelf water depths, although a notable deepening to outer shelfal depths (correlated to the interval just above the early/middle Pleistocene hiatus) was noted in Samples 317-U1353B-10H-CC and 11H-CC (67.5$73.19 \mathrm{~m}$ ). Pliocene water depths were generally subtidal to inner shelf but ranged down to outer shelf in the early Pliocene. Middle-early Miocene paleowater depths could not be interpreted because of low numbers of benthic foraminifers.

\section{Paleomagnetism}

NRM was measured on all but the most disturbed cores from Site U1353. NRM intensities are on the order of $10^{-3}-10^{-2} \mathrm{~A} / \mathrm{m}$ and decrease to $10^{-4}-10^{-3} \mathrm{~A} / \mathrm{m}$ by $\mathrm{AF}$ demagnetization at peak fields of $20 \mathrm{mT}$. A steep, northerly, positive drilling overprint was removed by AF peak demagnetization at $20 \mathrm{mT}$ from APC cores recovered using nonmagnetic core barrels (Hole U1353B, 0-67.6 m). After demagnetization, remanence direction was oriented upward, or negative (normal), with a mean inclination around $-60^{\circ}$, consistent with a Brunhes age for this component. The overprint persisted (with declinations clustered at north) where standard steel core barrels were used at greater depths. Consequently, no reversals could be detected at Site U1353.

Rock magnetic experiments reveal lithology-dependent changes in magnetic behavior between gray muds and green silty/sandy intervals in Hole U1353B. Gray muds show relatively higher coercivities $(\sim 80 \mathrm{mT})$ and lose $\sim 80 \%$ of their remanence between $250^{\circ}$ and $360^{\circ} \mathrm{C}$ heating steps. Green, coarser grained sediments have coercivities of $\sim 40-50 \mathrm{mT}$ and lose only $40 \%-50 \%$ of their remanence between the same heating steps. Rock magnetic parameters are consistent with the presence of magnetic iron sulfides throughout the sediments and indicate the presence of an additional remanence carrier, likely magnetite, particularly in the greenish intervals.

\section{Physical properties}

In the uppermost $260 \mathrm{~m}$, systematic whole-round and/or section-half measurements of magnetic susceptibility, NGR, GRA bulk density, and $P$-wave velocities, as well as colorimetry and MAD measurements, revealed patterns of sedimentation characterized by cyclic variations as well as evidence suggestive of unconformities. Two abrupt excursions in magnetic susceptibility, NGR, and color occur between 13 and $17 \mathrm{~m}$ and between 27 and $36 \mathrm{~m}$ and 
are associated with thick sandy units. These peaks may correlate with the two most recent glacial-interglacial cycles, MIS 1-5 and 6-7, and provide tentative age estimates for the Holocene and latest Pleistocene.

Overall, magnetic susceptibility decreases, and $P$ wave velocity and bulk density increase downhole. Several abrupt shifts were observed in these trends. These shifts correspond to intervals where biostratigraphic evidence indicates a hiatus, and those intervals could be related to erosion or a missing section.

A number of prominent peaks in magnetic susceptibility in the uppermost $80 \mathrm{~m}$ may be linked to cavedin shell-hash material observed at the top of each core, as observed previously at Site U1351. These findings indicate that the noisy magnetic susceptibility signal below $\sim 100 \mathrm{~m}$ may also be mainly caused by the drilling process, including material that fell down onto the tops of cores (cave-in) or material that was sucked into the bottoms of core liners (flow-in). Caution is required before additional onshore analyses confirm or reinterpret tentative shipboard observations.

Good $P$-wave velocity results were obtained in the muddy portions of the sediment to $>585 \mathrm{~m}$. This contrasts with Sites U1351 and U1352, where high gas content in unlithified sediments destroyed the $P$ wave signal below the top $\sim 20 \mathrm{~m}$ of soft sediments.

AVS and FCP sediment strength tests correlate well in very soft and soft sediments, but AVS test values are about three times lower than FCP test values in firm to very stiff sediments. These findings, consistent with those at Sites U1351 and U1352, suggest that the applicability of the AVS test in firm to very stiff sediments is limited in that it underestimates the strength of such sediments.

\section{Geochemistry}

Gaseous hydrocarbon monitoring at Site U1353 did not show significant levels of hydrocarbons above the background laboratory air concentration of $\sim 2$ ppmv. Sulfate levels are never strongly depleted and no SMT is apparent, suggesting that either (1) methanogenesis did not occur in the sediments, (2) previously generated methane was lost when the shelf was emergent, or (3) methane was oxidized when sulfate was replenished by diffusion after a subsequent sea level rise.

Interstitial water chemistry in the uppermost $150 \mathrm{~m}$ is dominated by a salinity minimum, reaching values of 2.4 , or $70 \%$ of seawater, at $\sim 50 \mathrm{~m}$. Below this depth salinity increases again to seawater values and reaches a value slightly higher than that of seawater in the deepest sample at $586 \mathrm{~m}$. The presence of this less saline lens can be explained by either modern intrusion of meteoric water from land or by the historic remains of freshwater that was emplaced when the shelf was emergent and is now being slowly replaced by the downward diffusion of seawater. The profiles of chloride, sodium, sulfate, and, to some extent, potassium closely track the salinity trend and also show minima at $\sim 50 \mathrm{~m}$. Normalization of alkalinity, sulfate, calcium, and magnesium profiles to seawater chloride concentrations allows the evaluation of changes due to reaction rather than dilution with freshwater. Chloride-normalized alkalinity increases from $3.2 \mathrm{mM}$ near the seafloor to $9 \mathrm{mM}$ at $54 \mathrm{~m}$, which co-occurs with a depletion of $8 \mathrm{mM}$ in chloride-normalized sulfate. This implies that some sulfate reduction occurred and that alkalinity is affected by additional processes such as carbonate precipitation and dissolution. The normalized calcium concentrations increase with depth to $16 \mathrm{mM}$ and possibly reflect dissolution of calcareous microfossils. The chloride-normalized magnesium profile shows a steady decline downhole and levels out at $45 \mathrm{mM}$. Increasing boron concentrations indicate release of a desorbable boron fraction and degradation of organic matter. Similarly, the increasing lithium amounts can be explained by desorption reactions. Barium concentrations seem to be coupled to the sulfate profile and increase slightly when sulfate concentrations decline, possibly related to dissolution of barite.

Average carbonate content is highly variable but is lower below $300 \mathrm{~m}$. The decrease of TOC over the uppermost $100 \mathrm{~m}$ can be correlated with the intervals of alkalinity increase and sulfate decrease and might represent active biological oxidation. Pyrolysis characterization of organic matter suggests a major contribution from terrestrial plants, whereas $\mathrm{C} / \mathrm{N}$ ratios from elemental analysis are consistent with a significant marine influence.

\section{Heat flow}

One in situ temperature measurement was attempted with the third-generation advanced piston corer temperature tool (APCT-3), but it yielded poor results. Additional temperature measurements were not obtained because of difficult drilling conditions, and therefore heat flow could not be determined. Laboratory thermal conductivity measurements for the depth interval $5.2-413.5 \mathrm{~m}$ provide a range of 1.122-1.840 W/(m/K) and show two downhole-increasing trends: an increasing trend in the $0-32 \mathrm{~m}$ interval, with a local maximum at $\sim 30 \mathrm{~m}$, and a subsequent drop followed by another increasing trend to $413 \mathrm{~m}$. The origin of the local maximum at $\sim 30 \mathrm{~m}$ is unclear because porosity and bulk density are con- 
stant in the 20-50 m interval. In general, thermal conductivity varies positively with bulk density and negatively with porosity. Thermal conductivity measurements are unreliable below $414 \mathrm{~m}$.

\section{Downhole logging}

Downhole logging of dedicated logging Hole U1353C took place on 28 December 2009. Two tool strings were deployed: (1) a modified triple combo tool string (without radioactive sources because of unstable hole conditions at this site), which measured natural gamma ray and resistivity from the seafloor to a total depth of $528 \mathrm{~m} \mathrm{WSF}$, and (2) the FMSsonic tool string, which measured electrical resistivity images and sonic velocities from 105 to $249 \mathrm{~m}$ WSF. Below $249 \mathrm{~m}$ WSF the FMS-sonic tool string encountered a blockage that prevented it from reaching total depth.

Two units were identified in the logs. Logging Unit 1 (105-260 m WSF) is characterized by an increasing trend from the top of the unit to $180 \mathrm{~m}$ WSF. Below that interval the gamma ray trend decreases downhole to $250 \mathrm{~m}$ WSF. These trends are interrupted by abrupt high-amplitude lows in gamma radiation and peaks in resistivity and velocity that are interpreted as sandy intervals, many of which coincide with sand or gravel at corresponding depths in Hole U1353B. These features also show good correspondence to significant seismic reflections. Logging Unit 2 (260-528 m WSF) is characterized by overall decreasing trends with depth in gamma radiation and resistivity, with low variability. The top of the unit is roughly the same depth as the onset of low core recovery in Hole $\mathrm{U} 1353 \mathrm{~B}$ and the point at which the FMS-sonic tool string was unable to descend deeper into the hole, suggesting a change in the properties of the formation across the unit boundary.

\section{Site U1354}

\section{Background}

Hole U1354A

Position: $44^{\circ} 50.8281^{\prime} \mathrm{S}, 171^{\circ} 47.2096^{\prime} \mathrm{E}$

Start hole: 0415 h, 29 December 2009

End hole: 2300 h, 29 December 2009

Time on hole (d): 0.78

Seafloor (drill pipe measurement from rig floor, $\mathrm{m}$ DRF): 121.2 (APC mudline)

Distance between rig floor and sea level (m): 11.4

Water depth (drill pipe measurement from sea level, m): 109.8

Total depth (drill pipe measurement from rig floor, m DRF): 206.6

Total penetration (m DSF): 85.4
Total length of cored section (m): 83.4

Total core recovered $(\mathrm{m}): 84.43$

Core recovery (\%): 101

Total number of cores: 18

\section{Hole U1354B}

Position: $44^{\circ} 50.8367^{\prime} \mathrm{S}, 171^{\circ} 47.2069^{\prime} \mathrm{E}$

Start hole: 2300 h, 29 December 2009

End hole: 1245 h, 30 December 2009

Time on hole (d): 0.57

Seafloor (drill pipe measurement from rig floor, $\mathrm{m}$ DRF): 124.8 (APC mudline)

Distance between rig floor and sea level (m): 11.4

Water depth (drill pipe measurement from sea level, m): 113.4

Total depth (drill pipe measurement from rig floor, m DRF): 202.0

Total penetration (m DSF): 77.2

Total length of cored section $(\mathrm{m}): 77.2$

Total core recovered $(\mathrm{m}): 77.52$

Core recovery (\%): 100

Total number of cores: 15

\section{Hole U1354C}

Position: $44^{\circ} 50.8487^{\prime} \mathrm{S}, 171^{\circ} 47.2080^{\prime} \mathrm{E}$

Start hole: 0700 h, 31 December 2009

End hole: 1200 h, 2 January 2010

Time on hole (d): 2.21

Seafloor (drill pipe measurement from rig floor, $\mathrm{m}$ DRF): 124.8 (by proxy, Hole U1354B)

Distance between rig floor and sea level (m): 11.4

Water depth (drill pipe measurement from sea level, $\mathrm{m}): 113.4$

Total depth (drill pipe measurement from rig floor, m DRF): 509.0

Total penetration (m DSF): 384.2

Total length of cored section (m): 319.2

Total core recovered $(\mathrm{m}): 133.37$

Core recovery (\%): 42

Total number of cores: 35

Site U1354 (110 m water depth) is located on the mid-outer shelf within the Canterbury Bight between landward shelf Site U1353 and outer shelf Site U1351 within the Canterbury Basin drilling transect. Site U1354 occupies an intermediate position in the shelf portion of the Expedition 317 transect. Lithologies and paleoenvironments were thus expected to be intermediate between those at Sites U1351 and U1353.

Site U1354 penetrates a middle Miocene to Pleistocene section containing seismic sequence boundaries U8-U19. All sequence boundaries were penetrated landward of their rollovers, or paleoshelf edges, with the goal of recovering proximal facies, yielding evidence of shallow-water deposition, and providing 
optimal paleowater depths from benthic foraminiferal biofacies.

The principal objectives at Site U1354 were to (1) sample facies landward of rollovers of progradational seismic sequence boundaries U8-U19 and in particular to use benthic foraminiferal biofacies to estimate paleowater depths both above and below these sequence boundaries in order to calculate eustatic amplitudes using two-dimensional backstripping and (2) investigate the facies, paleoenvironments, and depositional processes associated with the sequence stratigraphic model in a proximal setting on a prograding continental margin where sequence architecture is well constrained by seismic imaging.

\section{Lithostratigraphy}

At Site U1354, Holocene to lower Pliocene sediments were drilled at a water depth and location intermediate between Site U1351 on the outer shelf and Site U1353 on the middle shelf. This site provides an excellent sedimentary record of deposition throughout the Holocene-Pleistocene period of eustatic sea level fluctuation. Some of the older lower PleistocenePliocene seismic reflectors in the offshore Canterbury Basin were penetrated at this site at relatively shallow subbottom depths. Core recovery was reduced below $175 \mathrm{~m}$, which hindered lithologic interpretation of the deeper parts of the section.

Lithologic changes suggest a progressive and gradual change in sedimentary style as the margin evolved and are consistent with similar observations made at other shelf sites. Cores recovered from Holes U1354A, U1354B, and U1354C show a downhole transition from a heterolithic upper section between 0 and $251 \mathrm{~m}$ with abrupt contacts (Unit I) to a more featureless, mud-dominated succession below $251 \mathrm{~m}$ (Unit II). Unit I is further divided into Subunits IA (0-146 $\mathrm{m})$ and IB (146-251 m).

Subunit IA is more heterolithic, containing dark greenish gray to olive-gray calcareous muddy sand, sandy marl, and homogeneous marl (e.g., Cores 317$\mathrm{U} 1354 \mathrm{~A}-1 \mathrm{H}$ and $317-\mathrm{U} 1354 \mathrm{~B}-10 \mathrm{H})$ and very dark gray, massive, quartz-rich, very well sorted very finefine sand (e.g., Cores 317-U1354A-7H and 317U1354B-7H). The ichnofabric index ranges between 1 and 5. Subunit IA also contains examples of sharp bioturbated contacts between very fine muddy sand (sometimes calcareous), above, and silty mud, below (e.g., Section 317-U1354B-13H-2). In contrast, Subunit IB lacks the aforementioned olive-gray marls and massive sands and is characterized by more repetitive assemblages of facies (e.g., Cores 317U1354C-19X and 21X) consisting of homogeneous greenish gray mud, which appears to be more clay rich (e.g., Sections 317-U1354C-18X-1 and 12X-2) than that of Subunit IA and which contains a minor calcareous component, and greenish gray to gray calcareous sandy mud to sandy marl that often contains calcareous concretions (e.g., Sample 317U1354C-21X-CC). The ichnofabric index ranges between 1 and 5.

The dominant Unit II lithology consists of very dark and dark greenish gray to gray micaceous, very fine sandy mud and mud, typically with shells. Both types of sediment have variable degrees of bioturbation ranging from absent to moderate (ichnofabric indexes of 1-3). Muddy very fine sand with shells occurs as a minor lithology.

Site U1354 is interpreted to represent a slightly more shoreline-proximal equivalent of Site U1351, but Unit I appears to represent a shallower water inner shelf setting compared to Sites U1351 and U1353. This is surprising because Site U1354 is today in shallower water. Evidence for shoreface and subtidal deposition, including potential paleosols, suggests that Subunit IA at Site U1354 might represent a shoaled region of deposition. Several sharp, subtle contacts, along with biostratigraphic evidence for hiatuses, are evidence that sea level variations controlled the depositional facies of Unit I. Unit II represents inner to middle shelf depositional settings during the Pliocene. Potential lithologic expression of seismic sequence boundaries can be matched between all three shelf sites.

\section{Biostratigraphy}

The Holocene to early Pliocene biostratigraphy of Site U1354 was based on the shipboard study of calcareous nannofossils, diatoms, and planktonic and benthic foraminifers in core catcher samples from Holes U1354A, U1354B, and U1354C. Additional intra-core samples were taken from selected cores to address specific age and paleoenvironmental questions using calcareous nannofossils. All microfossils groups were represented throughout the cored section, except for diatoms, which were only found in a few Pleistocene samples.

The Holocene to Pleistocene sections in Holes U1354A (0-85.4 m), U1354B (0-77.3 m), and U1354C (0-127.8 m) were primarily dated and divided with calcareous nannofossils. Two hiatuses were identified with nannofossil dating: (1) an intraPleistocene hiatus at $76.2-80.2 \mathrm{~m}$ in Hole U1354A and 73.7-73.9 $\mathrm{m}$ in Hole U1354B, where $\sim 0.3 \mathrm{~m} . \mathrm{y}$. was missing, and (2) a hiatus at the base of the Pleistocene at 122.2-133.4 $\mathrm{m}$ in Hole U1354C, where 1 m.y. was missing. Another potential hiatus was identified on the basis of calcareous nannofossil dating and magnetostratigraphic data in Holes U1354A and 
U1354B at 69.9 and $64.8 \mathrm{~m}$, respectively. Benthic foraminifers were generally indicative of subtidal to middle shelf depths throughout the Pleistocene, and planktonic foraminifers suggested deposition generally occurred under sheltered inner neritic conditions, except for short-lived excursions to outer neritic and extraneritic conditions.

The Pliocene section between 133 and $375 \mathrm{~m}$ was poorly dated, although calcareous nannofossils and planktonic foraminifers suggested that the age of the section was middle Pliocene $(>2.78 \mathrm{Ma}$, calcareous nannofossils) to late early Pliocene ( $>4.3 \mathrm{Ma}$, planktonic foraminifers). There was no biostratigraphic evidence for upper Pliocene sediments, which were probably missing at the level of the basal Pleistocene hiatus. Pliocene deposition occurred generally in inner shelf water depths, possibly ranging at times to middle shelf depths, under sheltered inner neritic conditions. The age at the bottom of Hole U1354C $(375.3 \mathrm{~m})$ was late early Pliocene (3.7-4.3 Ma), constrained by calcareous nannofossils and planktonic foraminifers.

\section{Paleomagnetism}

When possible, NRM was measured before and after demagnetization at $20 \mathrm{mT}$ peak fields. Persistent flux jumps in the superconducting rock magnetometer (SRM) rendered measurement difficult, and in some cases impossible, in the time available. In spite of this, a good, unambiguous record was recovered. The use of nonmagnetic core barrels throughout the overlapping Holes U1354A and U1354B allowed the identification of sediments holding reversed polarity from $\sim 69.9$ and $65 \mathrm{~m}$ downhole, respectively. The Brunhes/Matuyama boundary lies within an unconformity marked by a sharp lithologic boundary in both holes. Coring in Hole U1354C began just beneath this boundary and revealed sediments with reversed polarity of Matuyama age. Biostratigraphic constraints indicate that the Jaramillo Subchron (C1r.1n, 0.998-1.072 Ma) was not recorded in sediments from Site U1354. Below $78.1 \mathrm{~m}$, coring in Hole U1354C used the XCB system, which imparted a pervasive drilling overprint not fully removed during shipboard analyses.

\section{Physical properties}

Magnetic susceptibility, NGR, and color records show pronounced variations in the uppermost $\sim 170 \mathrm{~m}$ in all three holes, and these variations are similar to the patterns observed at other Expedition 317 sites. Changes in magnetic susceptibility, NGR, and color can be linked to changes in lithology. Color changes, in particular, highlight the utility of this parameter for distinguishing between sands and marls with low NGR and magnetic susceptibility. Abrupt changes in these records at 34 and $54 \mathrm{~m}$ also coincide with two changes in sulfate-methane abundances in Hole U1354A.

$P$-wave measurements yielded good results over the uppermost $217 \mathrm{~m}$. Good results were also gained from measurements made at Site U1353. At both Sites U1353 and U1354, the long record of good $P$ wave data can be ascribed to the absence of sediment fracturing caused by high gas content. A change between $\sim 68$ and $70 \mathrm{~m}$ in Hole U1354A and 64 and $65 \mathrm{~m}$ in Hole U1354B marks both a hiatus and the position of the Brunhes/Matuyama boundary. This boundary can also be recognized in NGR, magnetic susceptibility, and color data.

Decreases in porosity and void ratio and changes in bulk density are compatible with the porosity trends seen at the other sites. Grain density shows some scatter, reflecting the variable lithology at this site. Sediment strength measurements have a similar pattern to that observed at all Expedition 317 sites.

\section{Geochemistry}

Gaseous hydrocarbon monitoring at Site U1354 revealed two peaks in methane content, one at 33$75 \mathrm{~m}$, where headspace methane increases to a peak of $23 \mathrm{ppmv}$ at $46 \mathrm{~m}$, and one below $\sim 200 \mathrm{~m}$, where headspace methane increases to $>20,000$ ppmv. Where sulfate is zero, methane begins to increase and then decreases to near background concentrations at $60 \mathrm{~m}$, the depth at which sulfate reappears in the cores. Sulfate is also fully depleted below 200 $\mathrm{m}$. The upper methane zone corresponds to a zone of rapid sedimentation, above which sulfate was depleted quickly by both organic matter oxidation (one-third) and AOM (two-thirds). In the 60-178 m depth interval the stoichiometry suggests that sulfate reduction was driven almost exclusively by AOM and that apparently sediments in this depth interval were deposited at a rate slow enough to permit continuous replenishment of dissolved sulfate by diffusion from overlying seawater.

One notable aspect of the shallow pore water chemistry profiles at Site U1354 is the lack of a low-salinity zone like that seen at $\sim 50 \mathrm{~m}$ at the more landward Site U1353. This helps clarify the origin of this low-salinity zone. Because the water depth at Site U1354 is only slightly deeper than at Site U1353, there is no reason to believe that these sites experienced significantly different exposure during lowstands caused by glaciation. Therefore, the presence of a less-saline lens at Site U1353 is most likely explained by modern intrusion of meteoric water from land rather than by the historic remains of freshwater emplaced when the shelf was emergent. 
Other changes in pore water chemistry at Site U1354 are probably related to carbonate diagenesis and possible contributions from deeper basinal brines. The main decreases in dissolved calcium and magnesium occur within the depth intervals characterized by sulfate reduction, methanogenesis, and AOM. These processes are commonly associated with precipitation of authigenic carbonates with distinct carbon isotopic compositions. The increase in sodium and chloride from 0 to $60 \mathrm{~m}$, possibly related to an influx of saline fluid, may also account for some of the other changes seen at Site U1354, such as the increases in barium, lithium, and boron with depth.

Because of time constraints at the end of the expedition, only 18 sediment samples were analyzed for carbonate content by the elemental analyzer. Calcium carbonate contents range from 1.3 to $52 \mathrm{wt} \%$ in the sediments analyzed down to burial depths of $81 \mathrm{~m}$. Organic carbon ranges from 0.02 to $1.1 \mathrm{wt} \%$, with the highest value at $50 \mathrm{~m}$. The ratio of TOC to TN generally decreases with depth, with the exception of some of the high-carbonate samples in the 73-76 $\mathrm{m}$ depth interval.

\section{Heat flow}

Two temperature measurements were made using the Sediment Temperature (SET) tool, but results were poor because of harsh coring conditions. Accordingly, it was impossible to determine the geothermal gradient and heat flow at Site U1354. Laboratory thermal conductivity ranges from 1.183 to $1.873 \mathrm{~W} /(\mathrm{m} \cdot \mathrm{K})$, showing a constant profile with depth. Overall thermal conductivity correlates negatively with porosity and positively with bulk density. However, the highest values $(>1.700 \mathrm{~W} /[\mathrm{m} \cdot \mathrm{K}])$ came from very fine-fine sand layers in Holes U1354A and U1354B that were not associated with low porosity and high bulk density, probably because the sand layers consist mainly of highly thermally conductive material such as quartz.

\section{Downhole logging}

Downhole logging of Hole U1354C took place on 2 January 2010. Based on the potential for unstable hole conditions, our previous experience logging shelf sites, and time constraints at the end of the expedition, we decided that a single logging run without radioactive sources was the most reasonable logging strategy for this site. A modified "sonic combo" tool string was deployed to measure natural gamma ray, sonic velocities, and electrical resistivity from the seafloor to $383 \mathrm{~m}$ WSF.

Two units were identified in the logs. Logging Unit 1 (110-285 m WSF) is characterized by an increasing trend in gamma radiation from the top of the unit to
185 m WSF, followed by a generally decreasing trend to the base of the unit, punctuated by abrupt high-amplitude lows in gamma radiation and peaks in resistivity and velocity. This unit is identical to logging Unit 1 at Site U1353, and the high-amplitude features at both sites correspond to coarser grained intervals in the cores. Preliminary synthetic seismograms show that the two most prominent sand-rich intervals coincide with U10 and U11. Logging Unit 2 (285-384 $\mathrm{m}$ WSF) is characterized by slightly decreasing trends in gamma radiation and resistivity, with limited variability and increasing velocity. Unit 2 at this site is similar to logging Unit 2 at Site U1353, which is characterized by low core recovery associated with sandy sediments.

\section{References}

Abbott, S.T., 1992. The mid-Pleistocene Waiomio Shellbed (c. 500-600 ky), Wanganui Basin, New Zealand. Alcheringa: Australas. J. Palaeontol., 16(2):171-180. doi:10.1080/03115519208619038

Abbott, S.T., and Carter, R.M., 1994. The sequence architecture of mid-Pleistocene (0.35-0.95 Ma) cyclothems from New Zealand: facies development during a period of known orbital control on sea-level cyclicity. In de Boer, P.L., and Smith, D.G. (Eds.), Orbital Forcing and Cyclic Sequences, Spec. Publ. Int. Assoc. Sedimentol., 19:367-394.

Abbott, S.T., and Carter, R.M., 1999. Stratigraphy of the Castlecliffian type section: 10 mid-Pleistocene sequences from the Wanganui coast, New Zealand. N. $Z$. J. Geol. Geophys., 42:91-111. http://www.royalsociety.org.nz/publications/journals/nzjg/1999/008/

Abbott, S.T., Naish, T.R., Carter, R.M., and Pillans, B.J., 2005. Sequence stratigraphy of the Nukumaruan stratotype (Pliocene-Pleistocene, c. 2.08-1.63 Ma), Wanganui Basin, New Zealand. J. R. Soc. N. Z., 35(1-2):123-150.

Adams, C.J.D., 1979. Age and origin of the southern Alps. In Walcott, R.I., and Cresswell, M.M. (Eds.), The Origin of the Southern Alps. Bull.-Roy. Soc. N. Z., 18:73-78.

Austin, J.A., Jr., Christie-Blick, N., Malone, M.J., et al., 1998. Proc. ODP, Init. Repts., 174A: College Station, TX (Ocean Drilling Program). doi:10.2973/ odp.proc.ir.174a.1998

Batt, G.E., Braun, J., Kohn, B., and McDougall, I., 2000. Thermochronological analysis of the dynamics of the southern Alps, New Zealand. Geol. Soc. Am. Bull., 112(2):250-266. doi:10.1130/00167606(2000)112<250:TAOTDO>2.3.CO;2

Berggren, W.A., Kent, D.V., Swisher, C.C., III, and Aubry, M.-P., 1995. A revised Cenozoic geochronology and chronostratigraphy. In Berggren, W.A., Kent, D.V., Aubry, M.-P., and Hardenbol, J. (Eds.), Geochronology, Time Scales and Global Stratigraphic Correlation. Spec. Publ.-SEPM (Soc. Sediment. Geol.), 54:129-212.

Billups, K., and Schrag, D.P., 2002. Paleotemperatures and ice volume of the past $27 \mathrm{Myr}$ revisited with paired $\mathrm{Mg}$ / 
$\mathrm{Ca}$ and ${ }^{18} \mathrm{O} /{ }^{16} \mathrm{O}$ measurements on benthic foraminifers. Paleoceanography, 17(1):1003. doi:10.1029/ 2000PA000567

Browne, G.H., and Field, B.D., 1988. A review of Cretaceous-Cenozoic sedimentation and tectonics, east coast, South Island, New Zealand. In James, D.P., and Leckie, D.A. (Eds.), Sequences, Stratigraphy, Sedimentology: Surface and Subsurface. Mem.-Can. Soc. Pet. Geol., 15:37-48.

Browne, G.H., and Naish, T.R., 2003. Facies development and sequence architecture of a late Quaternary fluvialmarine transition, Canterbury Plains and shelf, New Zealand: implications for forced regressive deposits. Sediment. Geol., 158(1-2):57-86. doi:10.1016/S00370738(02)00258-0

Cande, S.C., and Kent, D.V., 1995. Revised calibration of the geomagnetic polarity timescale for the Late Cretaceous and Cenozoic. J. Geophys. Res., 100(B4):60936095. doi:10.1029/94JB03098

Cande, S.C., and Stock, J.M., 2004. Pacific-Antarctic-Australia motion and the formation of the Macquarie Plate. Geophys. J. Int., 157(1):399-414. doi:10.1111/j.1365246X.2004.02224.X

Carter, L., Carter, R.M., McCave, I.N., and Gamble, J., 1996. Regional sediment recycling in the abyssal southwest Pacific Ocean. Geology, 24(8):735-738.

doi:10.1130/ 0091-7613(1996)024<0735:RSRITA >2.3.CO;2

Carter, R.M., 1985. The mid-Oligocene Marshall Paraconformity, New Zealand: coincidence with global eustatic sea-level fall or rise? J. Geol., 93(3):359-371. doi:10.1086/628957

Carter, R.M., 1988. Post-breakup stratigraphy of the Kaikoura Synthem (Cretaceous-Cenozoic), continental margin, southeastern New Zealand. N. Z. J. Geol. Geophys., 31:405-429.

Carter, R.M., 2007. The role of intermediate-depth currents in continental shelf-slope accretion: Canterbury Drifts, SW Pacific Ocean. In Viana, A.R., and Rebesco, M. (Eds.), Economic and Paleoceanographic Significance of Contourite Deposits. Geol. Soc. Spec. Publ., 276(1):129_ 154. doi:10.1144/GSL.SP.2007.276.01.07

Carter, R.M., Abbott, S.T., Fulthorpe, C.S., Haywick, D.W., and Henderson, R.A., 1991. Application of global sealevel and sequence-stratigraphic models in Southern Hemisphere Neogene strata from New Zealand. In Macdonald, D.I.M. (Ed.), Sedimentation, Tectonics, and Eustasy: Sea-level Changes at Active Margins. Spec. Publ. Int. Assoc. Sedimentol., 12:41-65.

Carter, R.M., Fulthorpe, C.S., and Lu, H., 2004a. Canterbury drifts at Ocean Drilling Program Site 1119, New Zealand: climatic modulation of southwest Pacific intermediate water flows since 3.9 Ma. Geology, 32(11):10051008. doi:10.1130/G20783.1

Carter, R.M., and Gammon, P., 2004. New Zealand maritime glaciation: millennial-scale southern climate change since 3.9 Ma. Science, 304(5677):1659-1662. doi:10.1126/science.1093726

Carter, R.M., Gammon, P.R., and Millwood, L., 2004b. Glacial-interglacial (MIS 1-10) migrations of the subtropi- cal front across ODP Site 1119, Canterbury Bight, Southwest Pacific Ocean. Mar. Geol., 205(1-4):29-58. doi:10.1016/S0025-3227(04)00017-9

Carter, R.M., and Landis, C.A., 1972. Correlative Oligocene unconformities in southern Australasia. Nature (London), Phys. Sci., 237:12-13.

Carter, R.M., McCave, I.N., and Carter, L., 2004c. Leg 181 synthesis: fronts, flows, drifts, volcanoes, and the evolution of the southwestern gateway to the Pacific Ocean, eastern New Zealand. In Richter, C. (Ed.), Proc. ODP, Sci. Results, 181: College Station, TX (Ocean Drilling Program), 1-111. doi:10.2973/odp.proc.sr.181.210.2004

Carter, R.M., and Norris, R.J., 1976. Cainozoic history of southern New Zealand: an accord between geological observations and plate-tectonic predictions. Earth Planet. Sci. Lett., 31(1):85-94. doi:10.1016/0012821X(76)90099-6

Chiswell, S.M., 1996. Variability in the Southland Current, New Zealand. N. Z. J. Mar. Freshwater Res., 30:1-17. http://www.royalsociety.org.nz/publications/journals/nzjm/1996/100/

Christie-Blick, N., 1991. Onlap, offlap, and the origin of unconformity-bounded depositional sequences. Mar. Geol., 97(1-2):35-56. doi:10.1016/00253227(91)90018-Y

Christie-Blick, N., Austin, J.A., Jr., and Shipboard Scientific Party, 1998. Introduction: Oligocene to Pleistocene eustatic change at the New Jersey continental margina test of sequence stratigraphy. In Austin, J.A., Jr., Christie-Blick, N., Malone, M.J., et al., Proc. ODP, Init. Repts., 174A: College Station, TX (Ocean Drilling Program), 516. doi:10.2973/odp.proc.ir.174A.101.1998

Christie-Blick, N., and Driscoll, N.W., 1995. Sequence stratigraphy. Annu. Rev. Earth Planet. Sci., 23(1):451-478. doi:10.1146/annurev.ea.23.050195.002315

Christie-Blick, N., Mountain, G.S., and Miller, K.G., 1990. Seismic stratigraphic record of sea-level change. In National Research Council (Ed.), Sea-level Change: Washington, DC (National Academy Press), 116-140.

Cloetingh, S., McQueen, H., and Lambeck, K., 1985. On a tectonic mechanism for regional sealevel variations. Earth Planet. Sci. Lett., 75(2-3):157-166. doi:10.1016/ 0012-821X(85)90098-6

Coombs, D.C.R., Kawach, Y., Landis, C.A., McDonough, W.F., and Reay, A., 1986, Cenozoic volcanism in north, east, and central Otago. In Smith, I.E.M. (Ed.), Late Cenozoic Volcanism in New Zealand. Bull-R. Soc. N. Z., 23:278-312.

COSOD II, 1987. Report of the 2nd Conference on Scientific Ocean Drilling: Washington/Strasbourg (JOIDES/European Sci. Found.).

Dewey, J.F., and Pitman, W.C., 1998. Sea level changes: mechanisms, magnitudes and rates. In Pindell, J.L., and Drake, C.L. (Eds.), Paleogeographic Evolution and Nonglacial Eustasy, Northern South America. Spec. Publ.-SEPM (Soc. Sediment. Geol.), 58:1-16.

Eberli, G., Swart, P., and Malone, M., 1996. ODP Prelim. Rept., 166. doi:10.2973/odp.pr.166.1996

Expedition 313 Scientists, 2010. New Jersey Shallow Shelf: shallow-water drilling of the New Jersey continental 
shelf: global sea level and architecture of passive margin sediments. IODP Prel. Rept., 313. doi:10.2204/

iodp.pr.313.2010

Field, B.D., and Browne, G.H., 1989. Cretaceous and Cenozoic Sedimentary Basins and Geological Evolution of Canterbury Region, South Island, New Zealand. N. Z. Geol. Surv., Basin Stud., 2.

Findlay, R.H., 1980. The Marshall Paraconformity. N. Z. J. Geol. Geophys., 23(1):125-133.

Fleming, C.A., 1962. New Zealand biogeography: a paleontologist's approach. Tuatara, 10:53-108.

Fulthorpe, C.S., Miller, K.G., Droxler, A.W., Hesselbo, S.P., Camoin, G.F., and Kominz, M.A., 2008. Drilling to decipher long-term sea-level changes and effects-a joint consortium for Ocean Leadership, ICDP, IODP, DOSECC, and Chevron workshop. Sci. Drill., 6:19-28. doi:10.2204/iodp.sd.6.02.2008

Fulthorpe, C.S., and Carter, R.M., 1989. Test of seismic sequence methodology on a Southern Hemisphere passive margin: the Canterbury Basin, New Zealand. Mar. Pet. Geol., 6(4):348-359. doi:10.1016/ 0264-8172(89)90031-7

Fulthorpe, C.S., and Carter, R.M., 1991. Continental-shelf progradation by sediment-drift accretion. Geol. Soc. Am. Bull., 103(2):300-309. doi:10.1130/ 0016-7606(1991)103<0300:CSPBSD >2.3.CO;2

Fulthorpe, C.S., Carter, R.M., Miller, K.G., and Wilson, J., 1996. Marshall paraconformity: a mid-Oligocene record of inception of the Antarctic Circumpolar Current and coeval glacio-eustatic lowstand? Mar. Pet. Geol., 13(1):61-77. doi:10.1016/0264-8172(95)00033-X

Haq, B.U., Hardenbol, J., and Vail, P.R., 1987. Chronology of fluctuating sea levels since the Triassic. Science, 235(4793):1156-1167. doi:10.1126/science.235.4793.1156

Hawkes, P.W., and Mound, D.G., 1984. Clipper-1 geological completion report. N. Z. Geol. Surv. Open-File Rep., 1036.

Hoernle, K., White, J.D.L., van den Bogaard, P., Hauff, F., Coombs, D.S., Werner, R., Timm, C., Garbe-Schönberg, D., Reay, A., and Cooper, A.F., 2006. Cenozoic intraplate volcanism on New Zealand: upwelling induced by lithospheric removal. Earth Planet. Sci. Lett., 248(1-2):350367. doi:10.1016/j.eps1.2006.06.001

Kamp, P.J.J., 1987. Age and origin of the New Zealand orocline in relation to alpine fault movement. J. Geol. Soc. (London, U. K.), 144(4):641-652. doi:10.1144/ gsjgs.144.4.0641

Karner, G.D., 1986. Effects of lithospheric in-plane stress on sedimentary basin stratigraphy. Tectonics, 5(4):573588. doi:10.1029/TC005i004p00573

Karner, G.D., Driscoll, N.W., and Weissel, J.K., 1993. Response of the lithosphere to in-plane force variations. Earth Planet. Sci. Lett., 114(4):397-416. doi:10.1016/ 0012-821X(93)90072-H

Kennett, J.P., and von der Borch, C.C., 1986. Southwest Pacific Cenozoic paleoceanography. In Kennett, J.P., von der Borch, C.C., et al., Init. Repts. DSDP, 90: Washington, DC (U.S. Govt. Printing Office), 1493-1517. doi:10.2973/dsdp.proc.90.148.1986
King, P.R., 2000. Tectonic reconstructions of New Zealand: 40 Ma to the present. N. Z. J. Geol. Geophys., 43:611638.

Kominz, M.A., 1984. Oceanic ridge volumes and sea-level change: an error analysis. In Schlee, J.S. (Ed.), Interregional Unconformities and Hydrocarbon Accumulation. AAPG Mem., 36:109-127.

Kominz, M.A., Miller, K.G., and Browning, J.V., 1998. Long-term and short-term global Cenozoic sea-level estimates. Geology, 26(4):311-314. doi:10.1130/00917613(1998)026<0311:LTASTG>2.3.CO;2

Kominz, M.A., and Pekar, S.F., 2001. Oligocene eustasy from two-dimensional sequence stratigraphic backstripping. Geol. Soc. Am. Bull., 113(3):291-304. doi:10.1130/ 0016-7606(2001)113<0291:OEFTDS >2.0.CO;2

Lavier, L.L., Steckler, M.S., and Brigaud, F., 2000. An improved method for reconstructing the stratigraphy and bathymetry of continental margins: application to the Cenozoic tectonic and sedimentary history of Congo margin. AAPG Bull., 78:923-939.

Lavier, L.L., Steckler, M.S., and Brigaud, F., 2001. Climatic and tectonic control on the Cenozoic evolution of the West African margin. Mar. Geol., 178(1-4):63-80. doi:10.1016/S0025-3227(01)00175-X

Lever, H., 2007. Review of unconformities in the late Eocene to early Miocene successions of the South Island, New Zealand: ages, correlation, and causes. N. Z. J. Geol. Geophys., 50(3):245-261. doi:10.1080/ 00288300709509835

Lewis, D.W., 1992. Anatomy of an unconformity on midOligocene Amuri limestone, Canterbury, New Zealand. N. Z. J. Geol. Geophys., 35(4):463-475.

Loutit, T.S. (Ed.), 1992. JOIDES Sea Level Working Group (SLWG) Report: Woods Hole, MA (Woods Hole Oceanographic Institute).

Lu, H., and Fulthorpe, C.S., 2004. Controls on sequence stratigraphy of a middle Miocene-Holocene, currentswept, passive margin: offshore Canterbury Basin, New Zealand. Geol. Soc. Am. Bull., 116(11):1345-1366. doi:10.1130/B2525401.1

Lu, H., Fulthorpe, C.S., and Mann, P., 2003. Three-dimensional architecture of shelf-building sediment drifts in the offshore Canterbury Basin, New Zealand. Mar. Geol., 193(1-2):19-47. doi:10.1016/S0025-3227(02)00612-6

Lu, H., Fulthorpe, C.S., Mann, P., and Kominz, M., 2005. Miocene-Recent tectonic and climate controls on sediment supply and sequence stratigraphy: Canterbury Basin, New Zealand. Basin Res., 17(2):311-328.

McGonigal, K., and Di Stefano, A., 2002. Calcareous nannofossil biostratigraphy of the Eocene-Oligocene Transition, ODP Sites 1123 and 1124. In Richter, C. (Ed.), Proc. ODP, Sci. Results, 181: College Station, TX (Ocean Drilling Program), 1-22. doi:10.2973/ odp.proc.sr.181.207.2002

McHugh, C.M.G., and Olson, H.C., 2002. Pleistocene chronology of continental margin sedimentation: new insights into traditional models, New Jersey. Mar. Geol., 186(3-4):389-411. doi:10.1016/ S0025-3227(02)00198-6 
Miall, A.D, and Miall, C.E., 2001. Sequence stratigraphy as a scientific enterprise: the evolution and persistence of conflicting paradigms. Earth Sci. Rev., 54(4):321-348. doi:10.1016/S0012-8252(00)00041-6

Miller, K.G., et al., 1994. Proc. ODP, Init. Repts., 150X: College Station, TX (Ocean Drilling Program). doi:10.2973/odp.proc.ir.150X.1994

Miller, K.G., Kominz, M.A., Browning, J.V., Wright, J.D., Mountain, G.S., Katz, M.E., Sugarman, P.J., Cramer, B.S., Christie-Blick, N., and Pekar, S.F., 2005. The Phanerozoic record of global sea-level change. Science, 310(5752):1293-1298. doi:10.1126/science.1116412

Miller, K.G., and Mountain, G.S., 1994. Global sea-level change and the New Jersey margin. In Mountain, G.S., Miller, K.G., Blum, P., et al., Proc. ODP, Init. Repts., 150: College Station, TX (Ocean Drilling Program), 11-20. doi:10.2973/odp.proc.ir.150.102.1994

Miller, K.G., Mountain, G.S., the Leg 150 Shipboard Party, and Members of the New Jersey Coastal Plain Drilling Project, 1996. Drilling and dating New Jersey Oligocene-Miocene sequences: ice volume, global sea level, and Exxon records. Science, 271(5252):1092-1095. doi:10.1126/science.271.5252.1092

Miller, K.G., Sugarman, P.J., Browning, J.V., et al., 1998. Proc. ODP, Init. Repts., 174AX: College Station, TX (Ocean Drilling Program). doi:10.2973/ odp.proc.ir.174AX.1998

Miller, K.G., Wright, J.D., and Fairbanks, R.G., 1991. Unlocking the ice house: Oligocene-Miocene oxygen isotopes, eustasy, and margin erosion. J. Geophys. Res., 96(B4):6829-6848. doi:10.1029/90JB02015

Milne, A.D., Simpson, C., and Threadgold, P., 1975. Resolution-1 well completion report. N. Z. Geol. Surv. OpenFile Rep., 648.

Mitchum, R.M., Vail, P.R., and Thompson, S., 1977. Seismic stratigraphy and global changes of sea level, part 2 : The depositional sequence as a basic unit for stratigraphic analysis. In Payton, C.E. (Ed.), Seismic Stratigraphy: Applications to Hydrocarbon Exploration. AAPG Mem., 26:53-62.

Molnar, P., Atwater, T., Mammerickx, J., and Smith, S., 1975. Magnetic anomalies, bathymetry and the tectonic evolution of the South Pacific since the Late Cretaceous. Geophys. J. R. Astron. Soc., 40:383-420.

Morono, Y., Terada, T., Masui, N., and Inagaki, F., 2009. Discriminative detection and enumeration of microbial life in marine subsurface sediments. ISME J., 3(5):503511. doi:10.1038/ismej.2009.1

Morris, M., Stanton, B., and Neil, H., 2001. Subantarctic oceanography around New Zealand: preliminary results from an ongoing survey. N. Z. J. Mar. Freshwater Res., 35:499-519.

Mountain, G.S., Miller, K.G., Blum, P., et al., 1994. Proc. ODP, Init. Repts., 150: College Station, TX (Ocean Drilling Program). doi:10.2973/odp.proc.ir.150.1994

Naish, T.R., Wehland, F., Wilson, G.S., Browne, G.H., Cook, R.A., Morgans, H.E.G., Rosenberg, M., King, P.R., Smale, D., Nelson, C.S., Kamp, P.J.J., and Ricketts, B., 2005. An integrated sequence stratigraphic, palaeoenvironmental, and chronostratigraphic analysis of the Tangahoe
Formation, southern Taranaki coast, with implications for mid-Pliocene (c. 3.4-3.0 Ma) glacio-eustatic sea level changes. J. R. Soc. N. Z., 35(1-2):151-196. http:// www.royalsociety.org.nz/publications/journals/nzjr/ 2005/006/

Nelson, C.S., and Cooke, P.J., 2001. History of oceanic front development in the New Zealand sector of the Southern Ocean during the Cenozoic-a synthesis. $N$. Z. J. Geol. Geophys., 44:535-553. http://www.royalsociety.org.nz/publications/journals/nzjg/2001/038/

Norris, R.J., Carter, R.M., and Turnbull, I.M., 1978. Cainozoic sedimentation in basins adjacent to a major continental transform boundary in southern New Zealand. $J$. Geol. Soc. (London, U. K.), 135(2):191-205. doi:10.1144/ gsjgs.135.2.0191

Osterberg, E.C., 2006. Late Quaternary (marine isotope stages 6-1) seismic sequence stratigraphic evolution of the Otago continental shelf, New Zealand. Mar. Geol., 229(3-4):159-178. doi:10.1016/j.margeo.2006.03.005

Posamentier, H.W., Jervey, M.T., and Vail, P.R., 1988. Eustatic controls on clastic deposition, I. Conceptual framework. In Wilgus, C.K., Hastings, B.S., Ross, C.A., Posamentier, H.W., Van Wagoner, J., and Kendall, C.G.St.C. (Eds.), Sea-Level Changes: An Integrated Approach. Spec. Publ.-Soc. Econ. Paleontol. Mineral., 42:109-124.

Posamentier, H.W., and Vail, P.R., 1988. Eustatic controls on clastic deposition, II: Sequence and systems tract models. In Wilgus, C.K., Hastings, B.S., Ross, C.A., Posamentier, H.W., Van Wagoner, J., and Kendall, C.G.St.C. (Eds.), Sea-Level Changes: An Integrated Approach. Spec. Publ.-Soc. Econ. Paleontol. Mineral., 42:125-154.

Reyes, A.G., 2007. Abandoned oil and gas wells: a reconnaissance study of an unconventional geothermal resource. GNS Sci. Rep., 2007/23.

Reynolds, D.J., Steckler, M.S., and Coakley, B.J., 1991. The role of the sediment load in sequence stratigraphy: the influence of flexural isostasy and compaction. J. Geophys. Res., [Solid Earth], 96(B4):6931-6949. doi:10.1029/ 90JB01914

Saul, G., Naish, T.R., Abbott, S.T., and Carter, R.M., 1999. Sedimentary cyclicity in the marine Pliocene-Pleistocene of the Wanganui Basin (New Zealand): sequence stratigraphic motifs characteristic of the past $2.5 \mathrm{~m}$.y. Geol. Soc. Am. Bull., 111(4):524-537. doi:10.1130/00167606(1999)111<0524:SCITMP>2.3.CO;2

Shipboard Scientific Party, 1999a. Leg 181 summary: southwest Pacific paleoceanography. In Carter, R.M., McCave, I.N., Richter, C., Carter, L., et al., Proc. ODP, Init. Repts., 181: College Station, TX (Ocean Drilling Program), 1-80. doi:10.2973/odp.proc.ir.181.101.2000

Shipboard Scientific Party, 1999b. Site 1119: drift accretion on Canterbury Slope. In Carter, R.M., McCave, I.N., Richter, C., Carter, L., et al., Proc. ODP, Init. Repts., 181: College Station, TX (Ocean Drilling Program), 1-112. doi:10.2973/odp.proc.ir.181.103.2000

Steckler, M.S., Mountain, G.S., Miller, K.G., and ChristieBlick, N., 1999. Reconstruction of Tertiary progradation and clinoform development on the New Jersey passive 
margin by 2-D backstripping. Mar. Geol., 154(1-4):399420. doi:10.1016/S0025-3227(98)00126-1

Tippett, J.M., and Kamp, P.J.J., 1993a. Fission track analysis of the late Cenozoic vertical kinematics of continental Pacific crust, South Island, New Zealand. J. Geophys. Res., [Solid Earth Planets], 98(9):16119-16148.

Tippett, J.M., and Kamp, P.J.J., 1993b. The role of faulting in rock uplift in the Southern Alps, New Zealand. N. Z. J. Geol. Geophys., 36(4):497-504.

Vail, P.R., Audemard, F., Bowman, S.A., Eisner, P.N., and Perez-Cruz, G., 1991. The stratigraphic signatures of tectonics, eustasy, and sedimentology-an overview. In Einsele, G., Ricken, W., and Seilacher, A. (Eds.), Cycles and Events in Stratigraphy: Berlin (Springer), 617-659.

Van Wagoner, J.C., Posamentier, H.W., Mitchum, R.M., Jr., Vail, P.R., Sarg, J.F., Loutit, T.S., and Hardenbol, J., 1988. An overview of the fundamentals of sequence stratigraphy and key definitions. In Wilgus, C.K., Hastings, B.S., Ross, C.A., Posamentier, H.W., Van Wagoner, J., and Kendall, C.G.St.C. (Eds.), Sea-Level Changes: An Integrated Approach. Spec. Publ.-Soc. Econ. Paleontol. Mineral., 42:39-45.

Walcott, R.I., 1998. Modes of oblique compression: late Cenozoic tectonics of the South Island of New Zealand. Rev. Geophys., 36(1):1-26. doi:10.1029/97RG03084
Ward, D.M., and Lewis, D.W., 1975. Paleoenvironmental implications of storm-scoured ichnofossiliferous midTertiary limestones, Waihao District, South Canterbury, New Zealand. N. Z. J. Geol. Geophys., 18:881-908.

Watkins, J.S., and Mountain, G.S. (Eds.), 1990. Role of ODP Drilling in the Investigation of Global Changes in Sea Level [JOI/USSAC Workshop, El Paso, TX, 24-26 October 1988].

Watters, W.A., 1978. Tertiary volcanism-Miocene. In Suggate, P.R., and Stevens, G.R. (Eds.), The Geology of New Zealand: Wellington (New Zealand Govt. Printer), 2:637-644.

Wellman, H.W., 1971. Age of the Alpine Fault, New Zealand. Proc Int. Geol. Congr, 22nd, 4:148-162.

Wilding, A., and Sweetman, I.A.D., 1971. Endeavour-1 petroleum report. N. Z. Geol. Surv. Open-File Rep., 303.

Wilson, I.R., 1985. Galleon-1 geological completion report. N. Z. Geol. Surv. Open-File Rep., 1146.

Publication: 4 January 2011

MS 317-101 
Figure F1. Map of the Canterbury Basin on the eastern margin of South Island, New Zealand. Inset map shows Expedition 317 site locations, with primary and alternate sites marked in red and yellow, respectively (also see Fig. F3). ODP = Ocean Drilling Program.

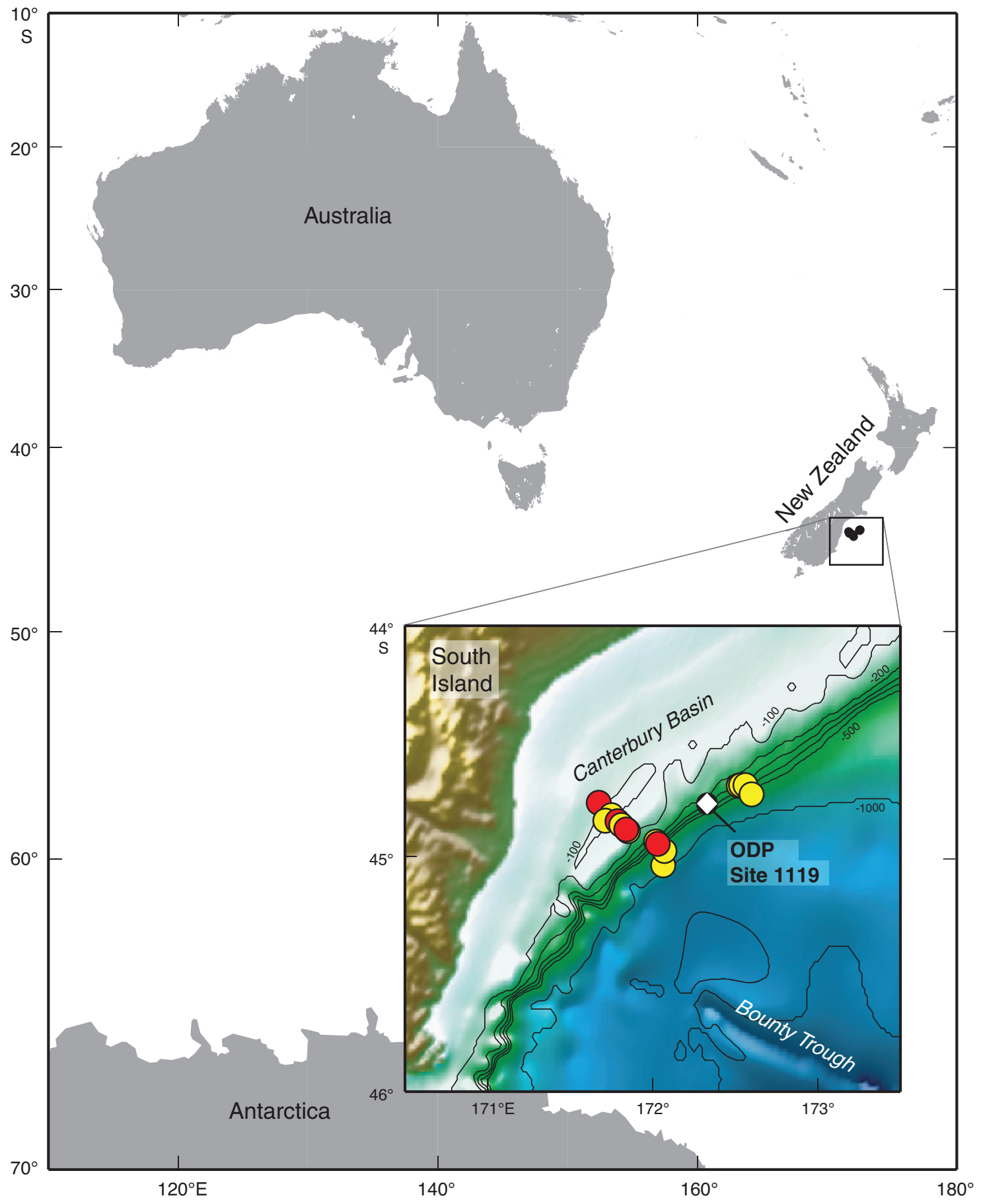


Figure F2. Bathymetric map of area drilled during Expedition 317. The Canterbury Basin underlies the presentday onshore Canterbury Plains and offshore continental shelf. It is bounded by the Miocene volcanic centers of the Banks Peninsula (BP) (5.8-12 Ma) (Watters, 1978) to the northeast and the Otago Peninsula (OP) (9.6$16.0 \mathrm{Ma}$ ) (Coombs et al., 1986; Hoernle et al., 2006) to the southwest and faces the Bounty Trough to the southeast. The Alpine Fault is the boundary between the Australasian and Pacific plates. Locations of the modern Southland Front and Subantarctic Front, together with a local gyre within the Bounty Trough, are shown (Chiswell, 1996; Shipboard Scientific Party, 1999a; Morris et al., 2001). Also shown are four exploration wells in the offshore basin (Resolution [R], Clipper [C], Endeavour [E], and Galleon [G]) as well as Ocean Drilling Program (ODP) Site 1119. A fifth well, Cutter, was drilled in 2006; information concerning Cutter, however, is sparse. Bathymetric contours are in meters.

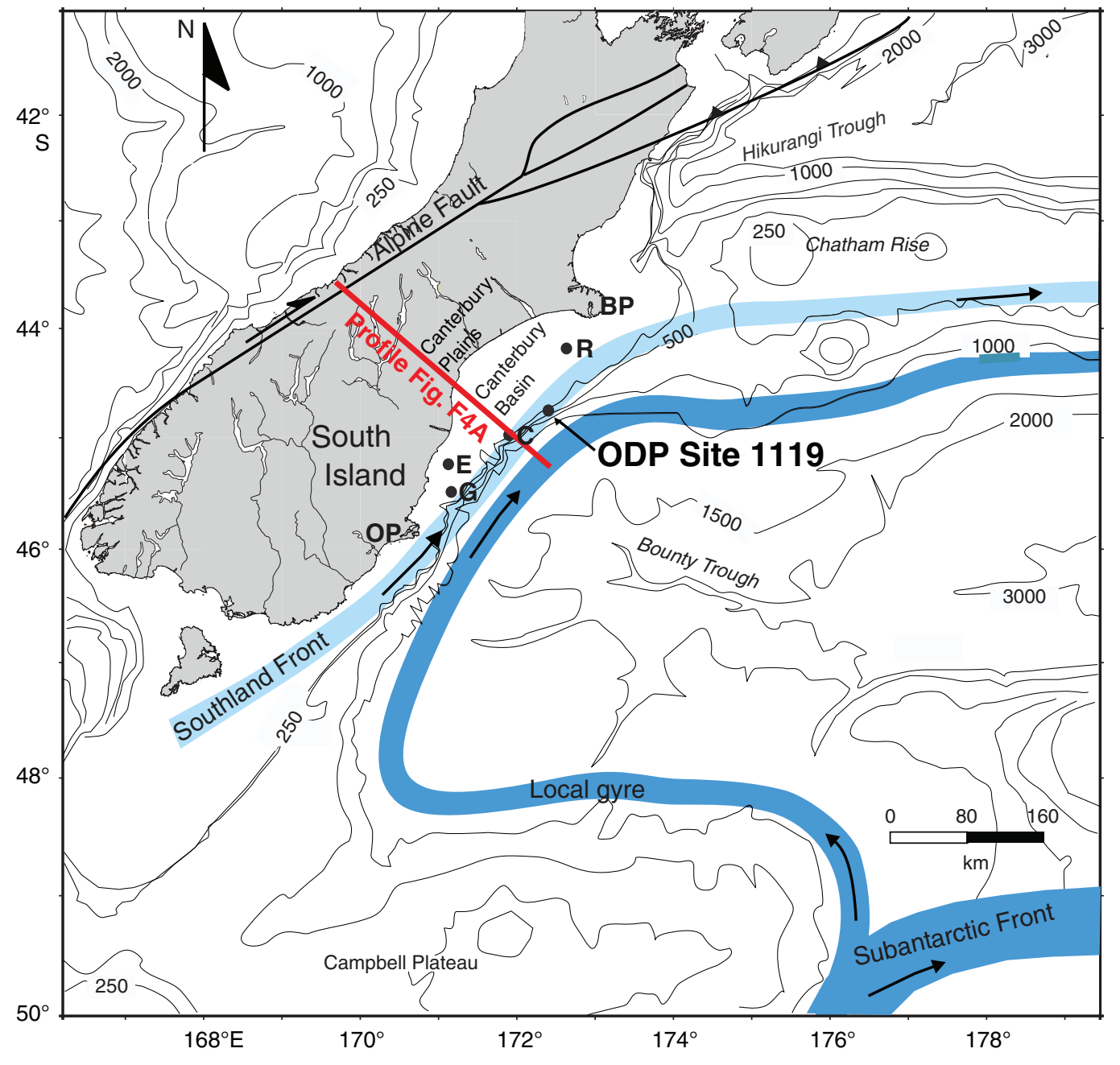


Figure F3. Drilled and proposed Expedition 317 sites, together with EW00-01 high-resolution (frequencies as high as $300 \mathrm{~Hz}$ ) multichannel seismic (MCS) grid (thick straight lines), low-resolution CB-82 commercial MCS grid (thin straight lines), exploration wells Clipper and Resolution, and Ocean Drilling Program (ODP) Site 1119. The EW00-01 survey was designed to provide improved vertical resolution ( $5 \mathrm{~m}$ in the upper $1 \mathrm{~s})$ to enhance our definition of high-frequency sedimentary sequences. Also shown is the distribution of seismically resolvable sediment drifts D1-D11 (blue curved lines = drift mound crests). D1-D6 and D10-D11 are simple, elongate drifts, and D7-D9 are complex drifts. D8 has three subdrifts (D8-1, D8-2, and D8-3) and is a multicrested complex drift. D9 is a multistage drift with superimposed subdrifts D9-1, D9-2, and D9-3. Dashed blue lines $=$ drifts identified on CB-82 profiles, thick black lines = locations of dip profiles shown in Figures F7, F8, and F9 $(66,12$, and 60, respectively). Other dip profiles containing alternate sites are also labeled $(12,14$, and 70). Bathymetric contours are in meters.

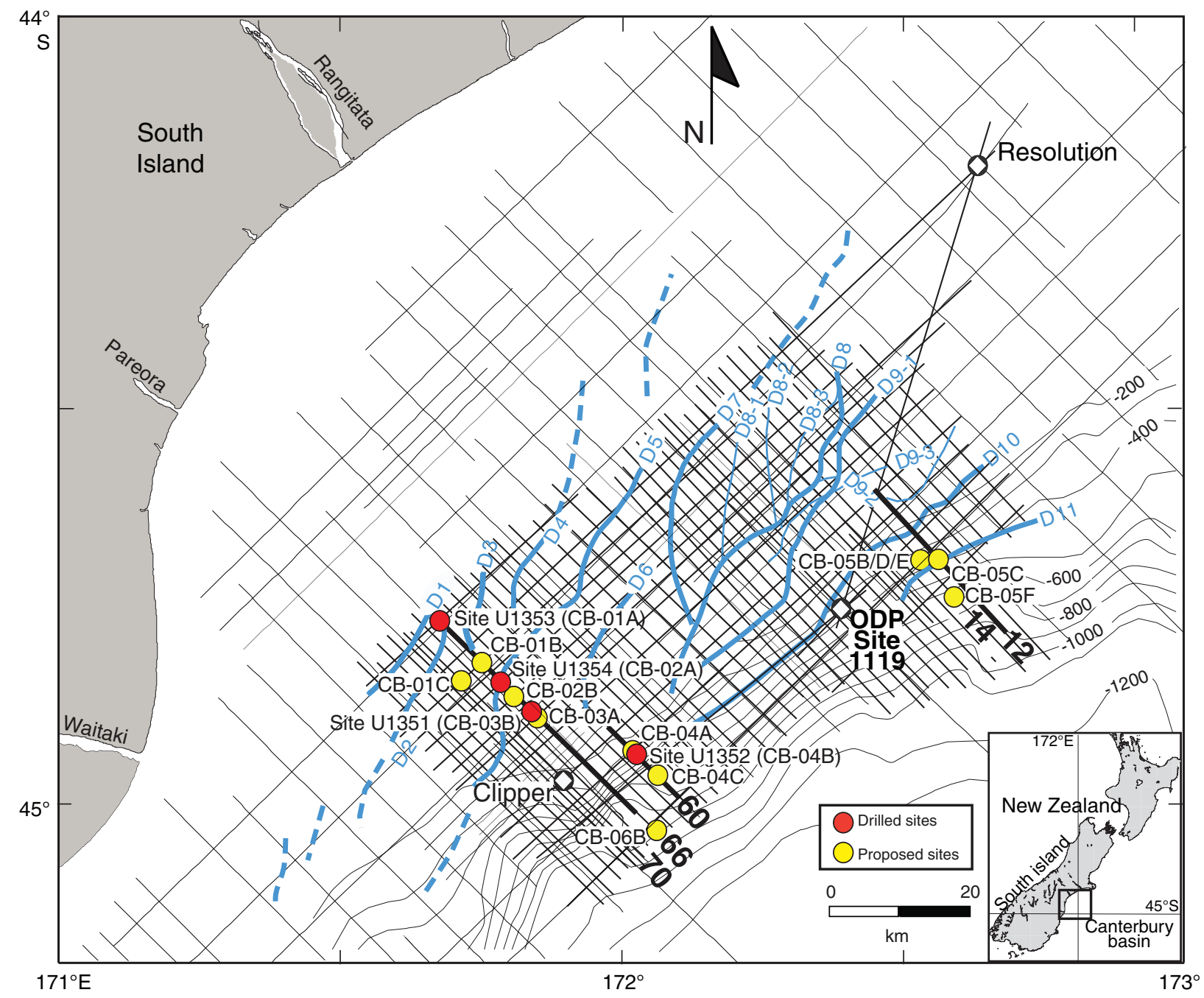


Figure F4. Schematic stratigraphy of the Canterbury Basin, drilled during Expedition 317, at three different scales. Modified from Fulthorpe et al. (1996). A. Large-scale postrift stratigraphy (see profile location in Fig. F2). Onekakara, Kekenodon, and Otakou groups were deposited during regional transgressive, highstand, and regressive phases, respectively. B. Seismic-scale stratigraphy. Sediment drifts occur within the Otakou Group. Limestones are shown as distal facies of the uppermost transgressive Onekakara Group and lowermost regressive Otakou Group. C. Outcrop-scale stratigraphy across the Marshall Paraconformity.

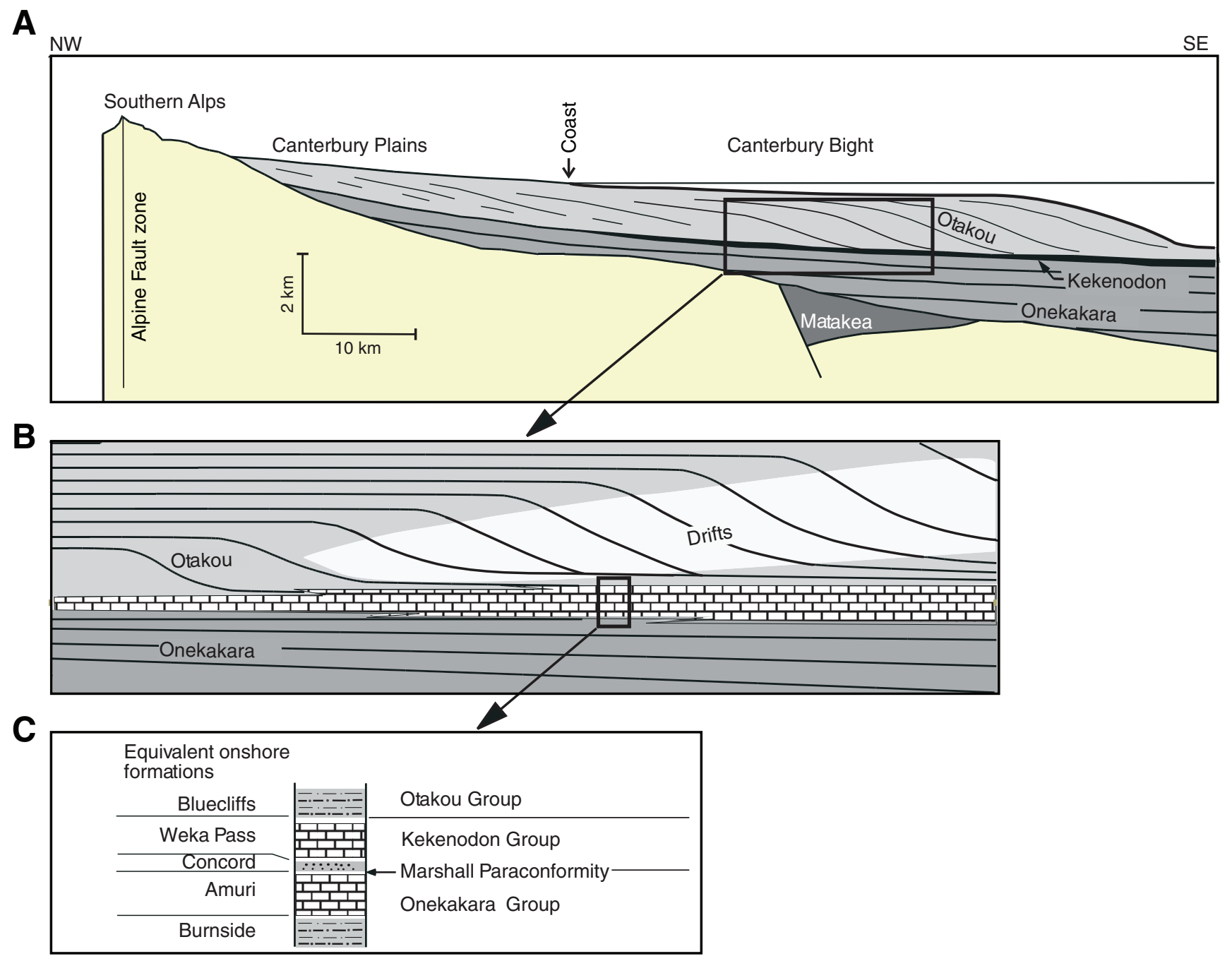


Figure F5. Total and tectonic subsidence curves for the Clipper exploration well (Fig. F2), with and without paleowater depth estimates, used during Expedition 317. Curve with paleowater depths shows that most tectonic subsidence occurred during the early Late Cretaceous, with mild uplift during the latest Cretaceous. Little tectonic subsidence has occurred during the last $30 \mathrm{~m} . \mathrm{y}$. The increase in the rate of tectonic subsidence beginning at $\sim 8$ Ma may be a response to increasing convergence at the Alpine Fault. Curves provided by R. Funnell, R. Wood, and G. Browne, GNS Science.

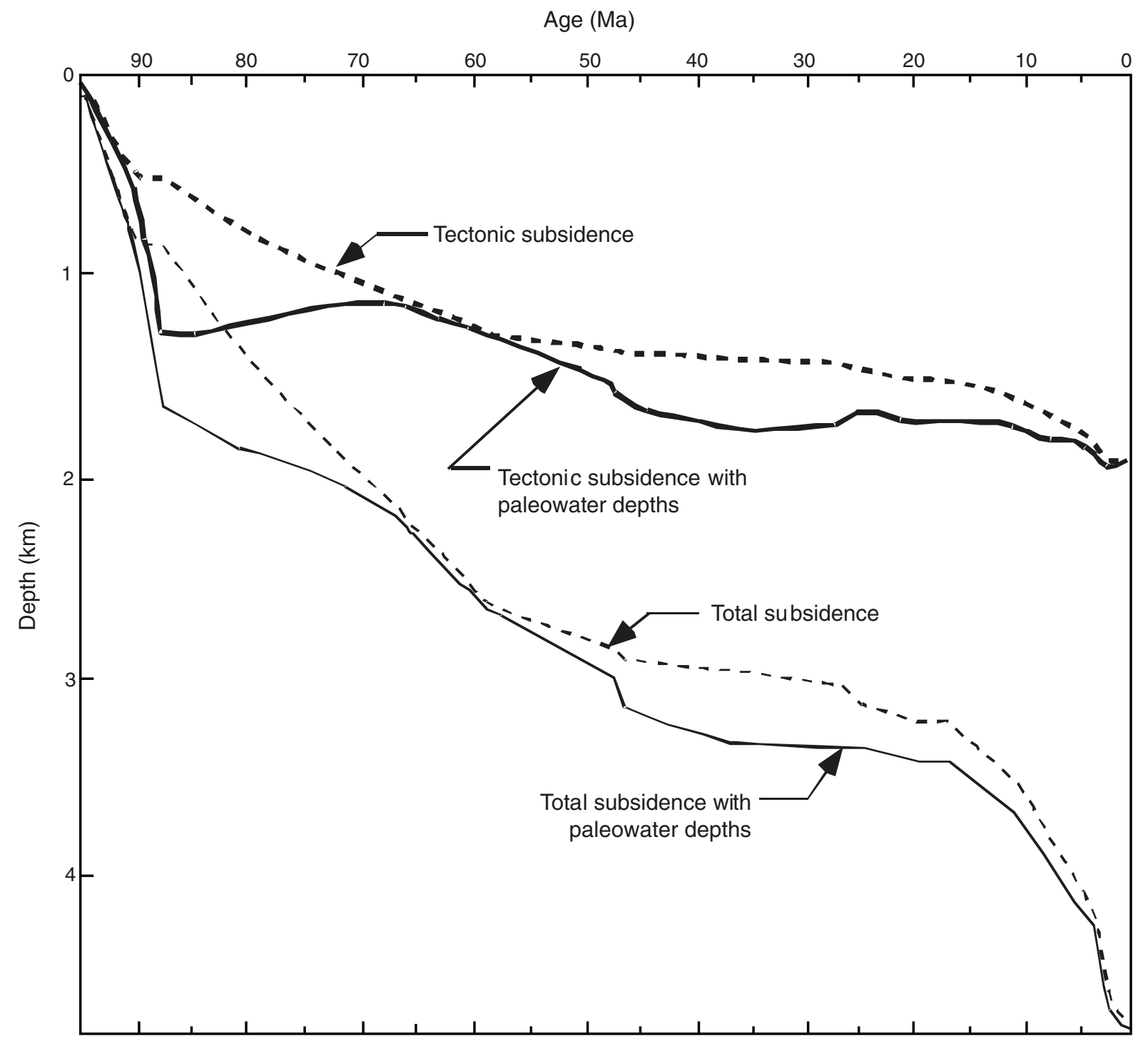


Figure F6. Revised subsidence analysis for the Clipper exploration well with eustatic estimates used during Expedition 317. A. Water depth (WD; blue), tectonic subsidence (red), and theoretical thermal curves (minimum and maximum) for the Clipper well (Figs. F2, F3). As Figure F5 also shows, most tectonic subsidence occurred during the early Late Cretaceous, with mild uplift during the latest Cretaceous. This analysis also shows the low rates of tectonic subsidence between 30 and $\sim 8 \mathrm{Ma}$ and the increase in total subsidence beginning at $\sim 8 \mathrm{Ma}$, which may be associated with increasing convergence at the Alpine Fault. B. R2, an estimate of eustasy, has large uncertainties because of the poorly constrained paleowater depths of much of the sediment preserved in the Clipper well (M. Kominz, unpubl. data). NJ = New Jersey.

A
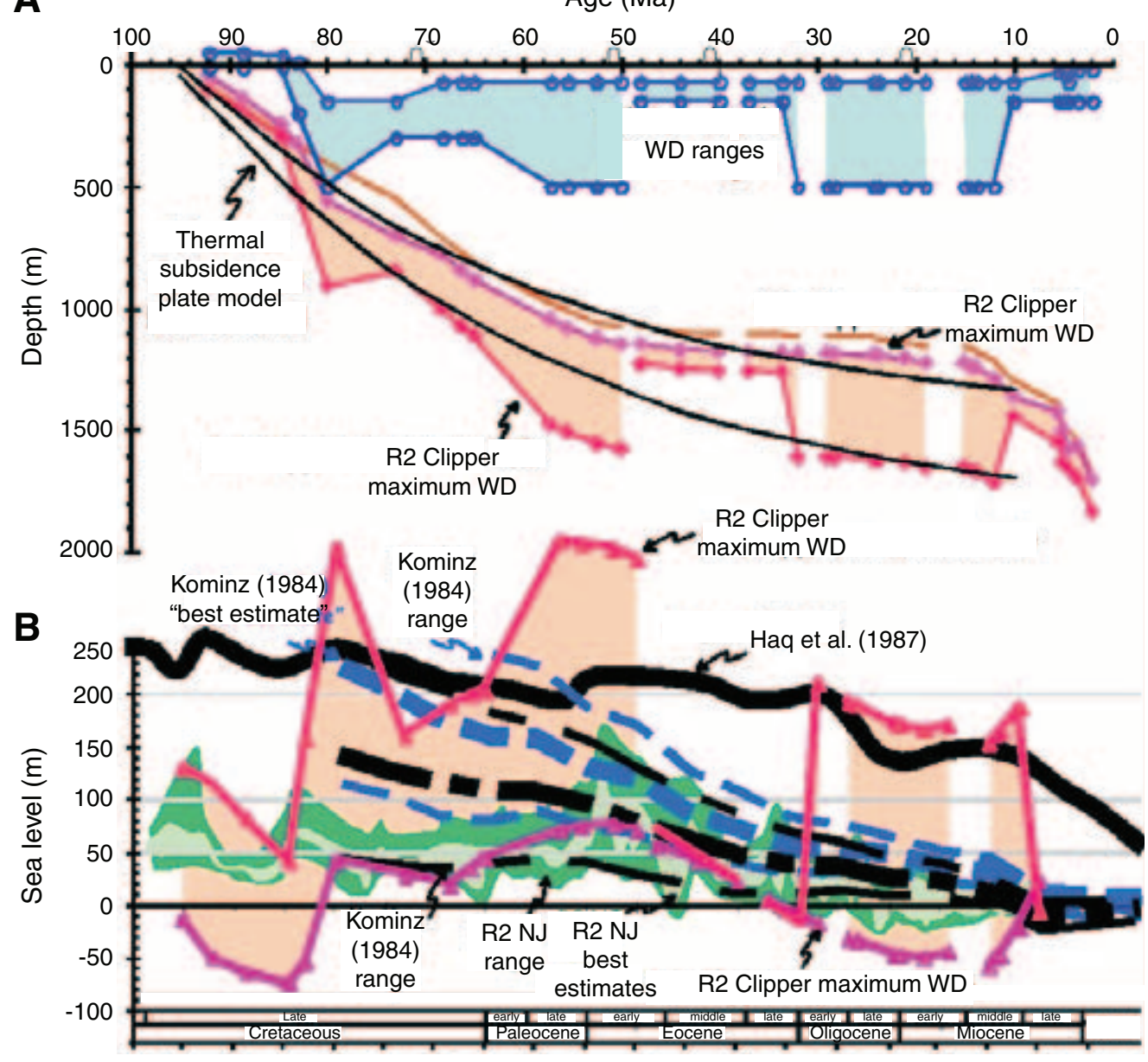
Figure F7. A. Uninterpreted multichannel seismic (MCS) dip Profile EW00-01-66 (southern part of survey grid) showing the locations of Sites U1351, U1353, and U1354. Proposed alternate Sites CB-01B, CB-02B, and CB03A are also shown (see Fig. F3 for location). Red = actual penetration, yellow = proposed penetration. B. Interpretation showing seismic sequence boundaries and selected locations of onlap, truncation, and downlap (arrows). Circles $=$ clinoform rollovers, or breaks, representing paleoshelf edges. Paleoshelf edges from seismic sequence boundaries U4 to U8 prograde steadily. Progradation decreases from U8 to U12, increasing again from U13 to U19. U4-U8 are onlapped and truncate underlying reflections; internal reflection geometries from U4 to U9 are mainly sigmoid. In contrast, U10-U19 are downlapped on paleoshelves but also truncate underlying reflections, and internal reflection geometries from U9 to the seafloor are oblique. Site U1351 sampled the paleoslopes of U6-U7 and sampled U8-U19 landward of their paleoshelf edges. Sites U1353 and U1354 sampled U5-U18 landward of their paleoshelf edges in a more proximal setting. Sediment drift development in this area largely ceased by U4. Only drift D5, capped by a postdrift slope platform at U4, was present. Prograding clinoforms dominate later sequences, and the slope steepens to $3^{\circ}-5^{\circ}$. Drifts migrate northwestward (landward) on dip profiles. Erosional unconformities at the landward edges of drift moats are diachronous and intersected by multiple sequence boundaries. (Figure shown on next page.) 


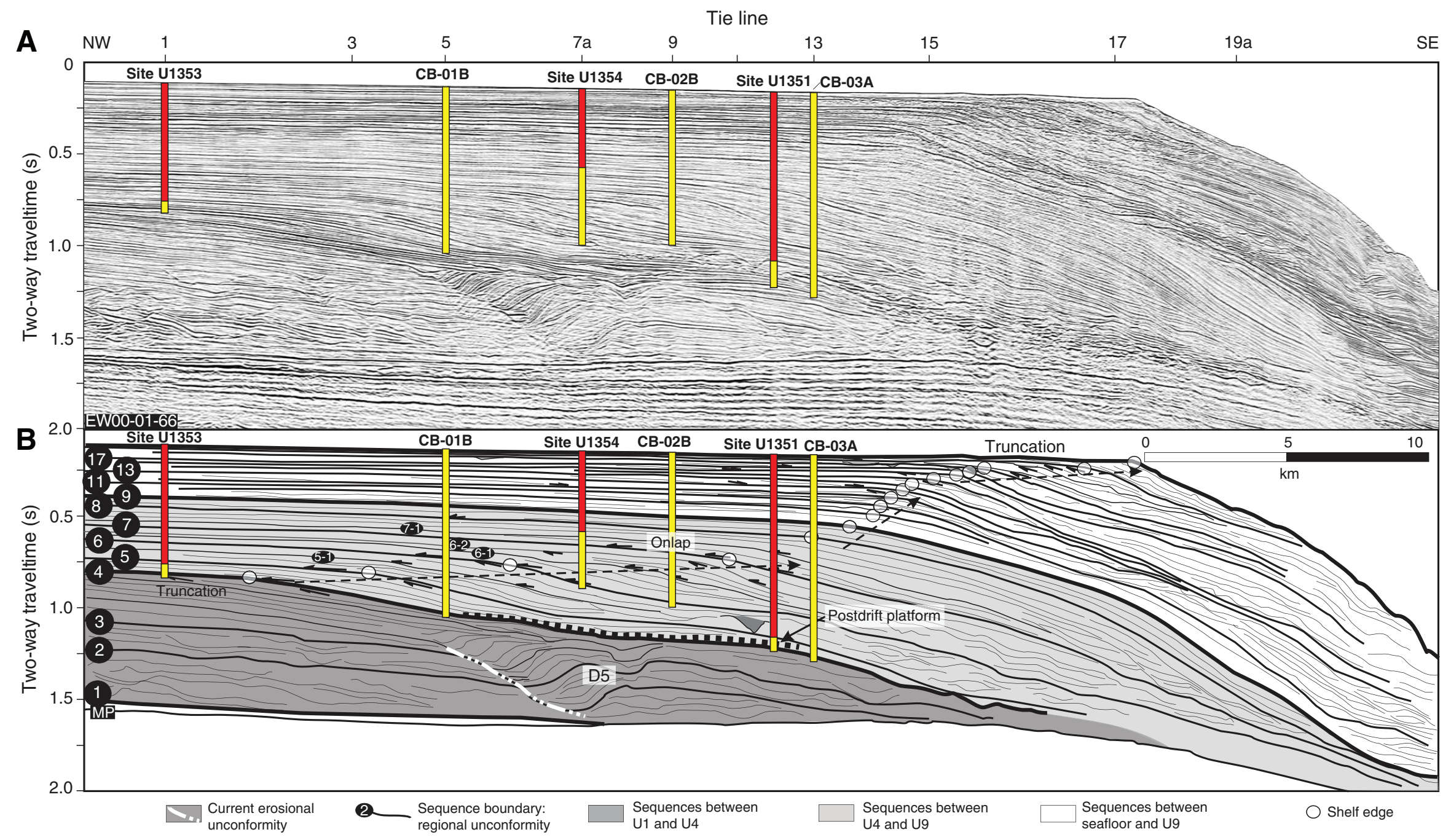


Figure F8. A. Uninterpreted dip Profile EW00-01-12 across the slope (northern part of survey grid; see Fig. F3 for location). B. Interpretation showing seismic sequence boundaries and selected locations of reflection truncation (arrows). Undrilled contingency Site CB-05C was selected to sample drift D11, the last of the large, elongate drifts of the Canterbury Basin. The underlying Marshall Paraconformity (MP) is also shown (see Fig. F4).

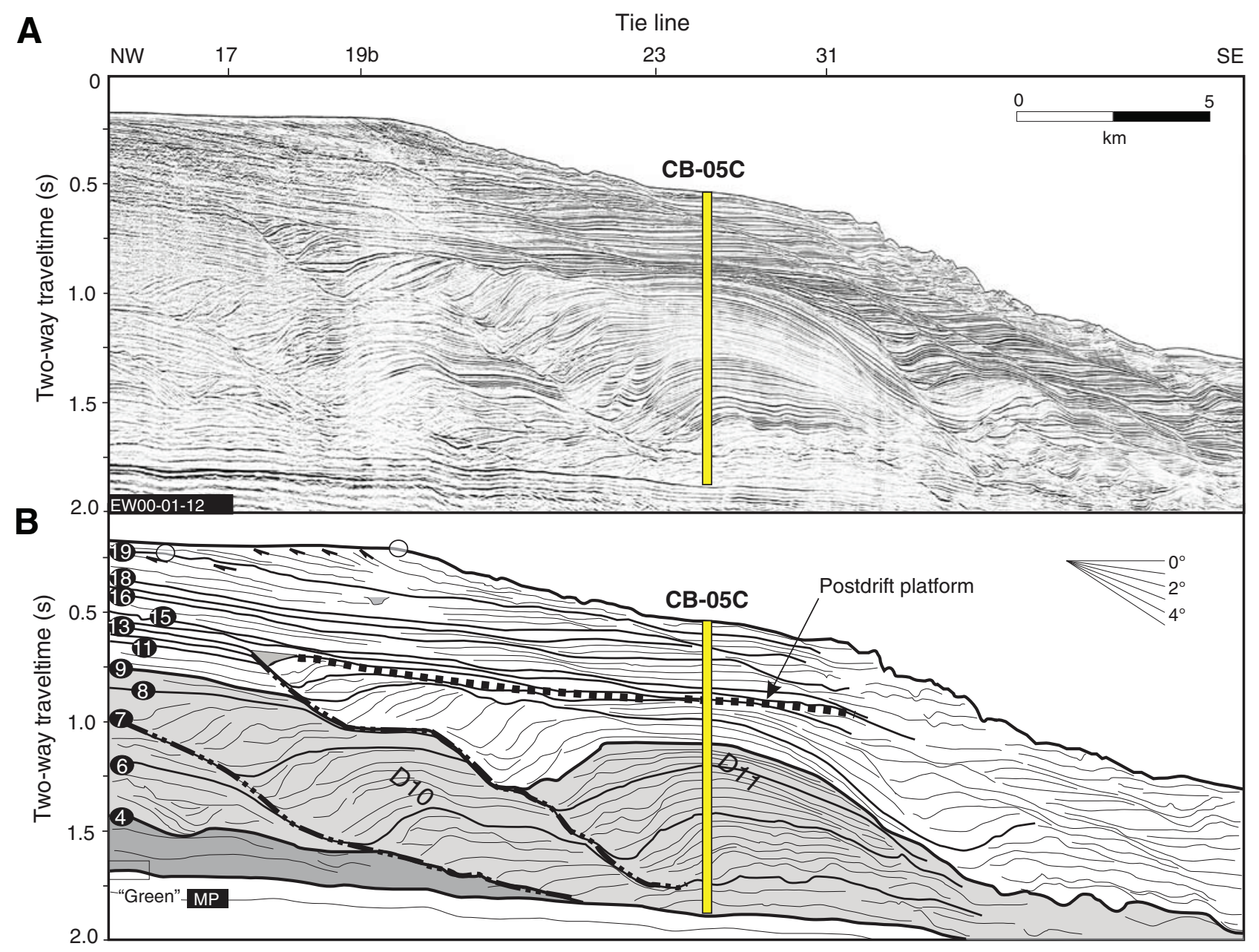


Figure F9. A. Uninterpreted dip Profile EW00-01-60 across the slope (southern part of survey grid; see Fig. F3 for location). B. Interpretation showing seismic sequence boundaries and selected locations of reflection truncation (arrows). Site U1352 sampled slope facies of sequences (particularly important for age control) and the underlying Marshall Paraconformity (MP). Alternate Site CB-04A is also shown. Red = actual penetration, yellow $=$ proposed penetration .

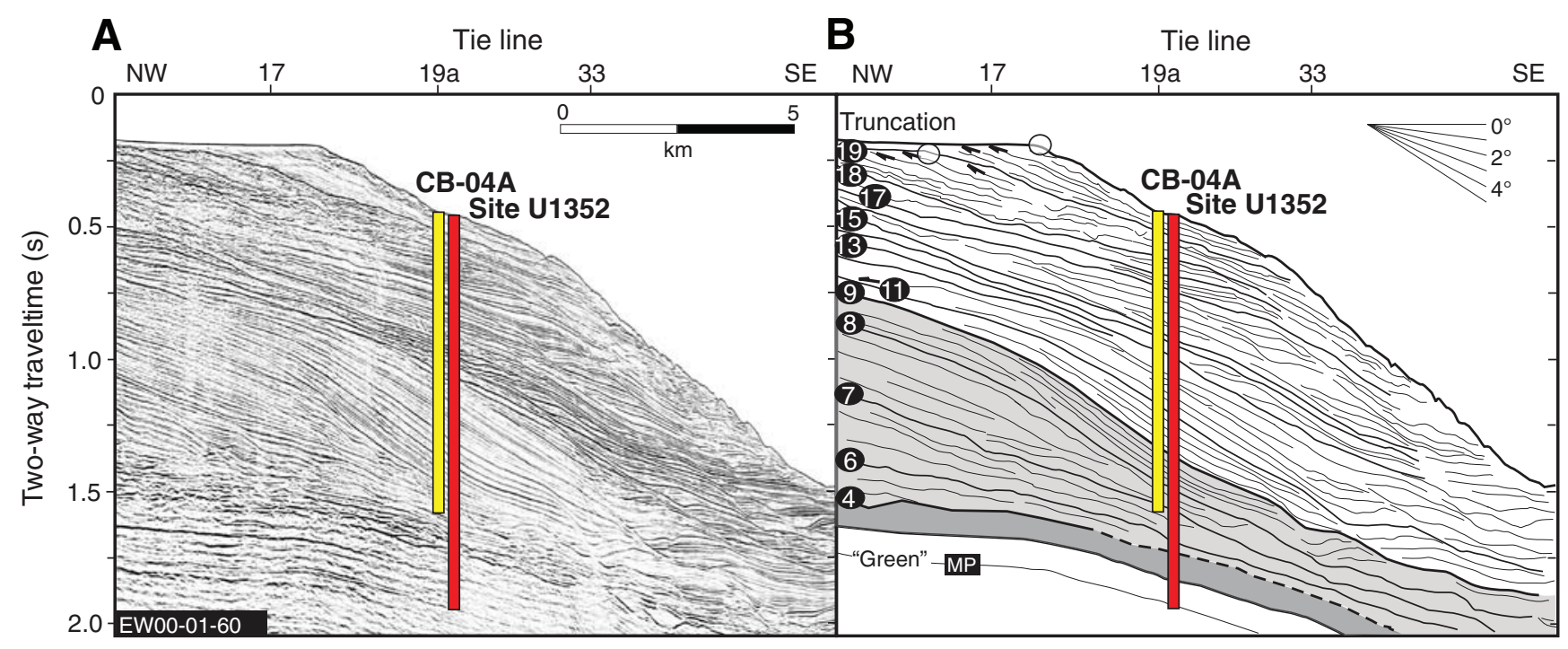


Figure F10. Comparison of multichannel seismic (MCS) profiles across a large sediment drift in the offshore Canterbury Basin used during Expedition 317. A. Colocated CB-82-22 commercial MCS profile. B. High-resolution EW00-01-12 MCS profile, showing the improved imaging of the high-resolution profile. The commercial profile has a vertical resolution of $\sim 20 \mathrm{~m}$, whereas that of the high-resolution profile is $\sim 5 \mathrm{~m}$ in the upper second.

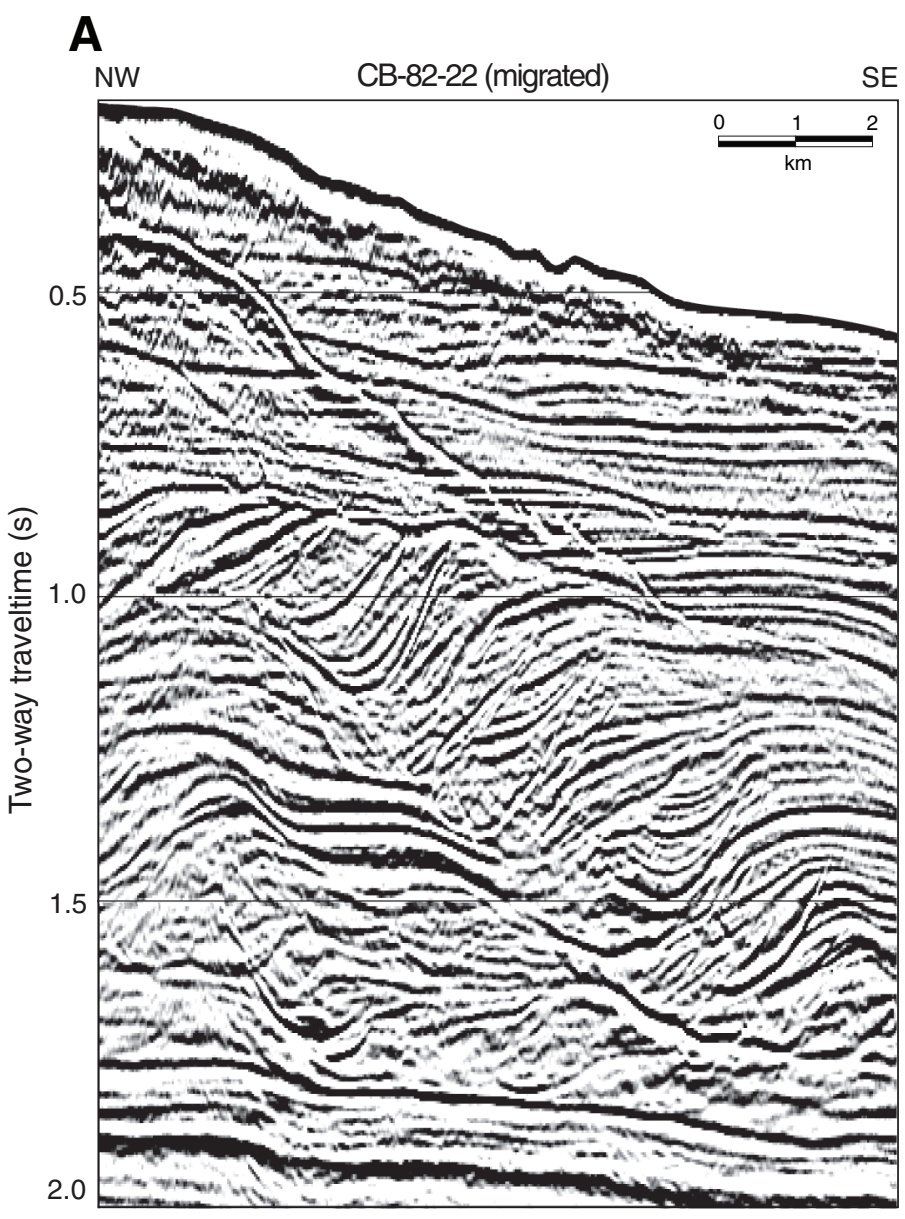

B

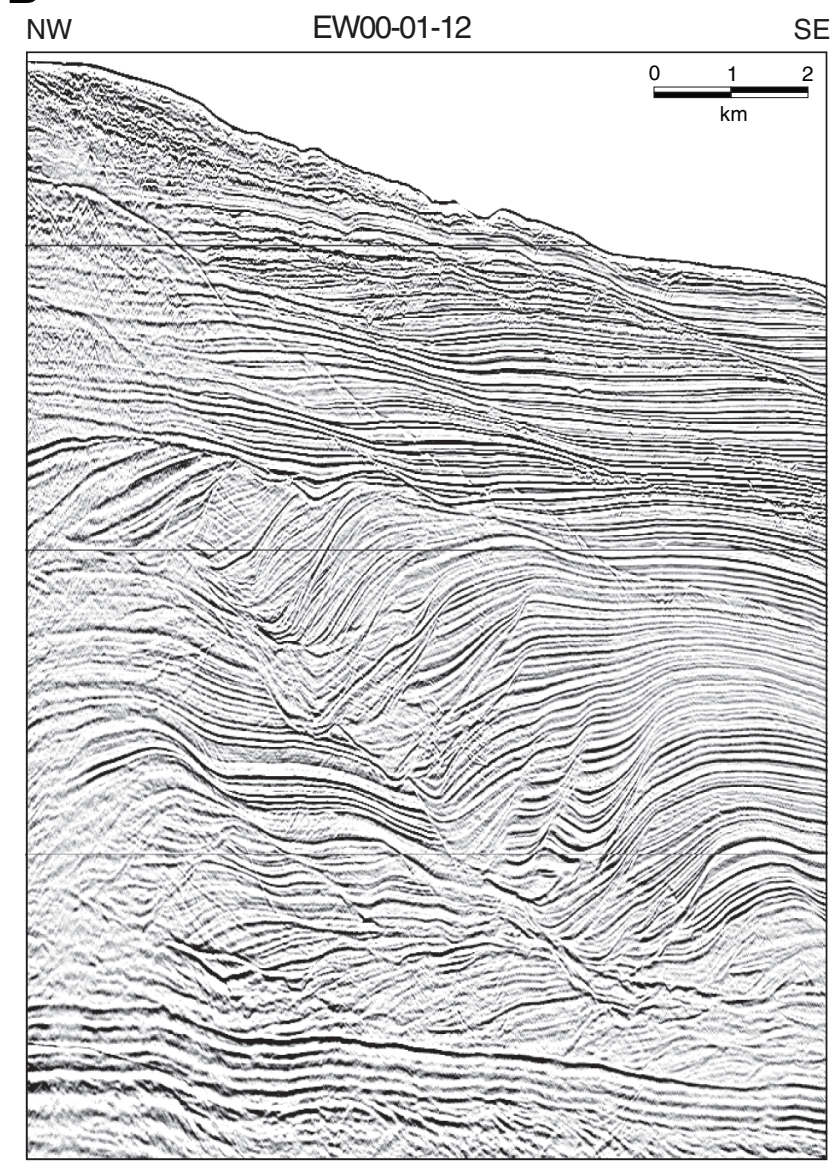


Figure F11. Predrilling age estimates of seismic sequence boundaries targeted during Expedition 317 and tentative correlation with oxygen isotopic record, sedimentation rates, and Alpine Fault convergence rates. Although predrilling age estimates are sometimes too old, they are close to drilling results, and tentative correlations remain valid. Two isotopic records are shown, both from Billups and Schrag (2002): (1) unmodified benthic foraminiferal $\delta^{18} \mathrm{O}$ record from ODP Site 747 ; (2) the same record corrected using $\mathrm{Mg} / \mathrm{Ca}$ thermometry to remove the temperature effect and yield the $\delta^{18} \mathrm{O}$ of seawater $\left(\delta^{18} \mathrm{O}_{\mathrm{sw}}\right)$, predominantly a response to ice volume and therefore an enhanced proxy for global sea level. The $\delta^{18} \mathrm{O}_{s w}$ record correlates better both with individual seismic sequences and longer term progradational and aggradational trends, as well as with the Haq et al. (1987) eustatic curve (also shown, recalibrated to the timescale of Berggren et al., 1995). This suggests eustatic control of sequence timing. Cooling Events Mi2, Mi3a, Mi3b, Mi4, and Mi5, derived from the oxygen isotope records from DSDP Site 608 and ODP Sites 703 and 704 (Miller et al., 1996) are shown. Average sedimentation rates are calculated from estimated sequence volumes ( $\mathrm{Lu}$ et al., 2005). The perpendicular component of motion at the Alpine Fault plate boundary was calculated using the method of Cande and Stock (2004). Finite rotations for Australia-Pacific motion were determined for four chrons (2A, $2.58 \mathrm{Ma} ; 3 \mathrm{~A}, 6.04$ Ma; 5, 11.53 Ma; 6, 20.13 Ma; ages are those of Cande and Kent [1995]). The increases in both sedimentation and convergence rates over the last 5-8 m.y. correlate well. The early phase of high sedimentation rates (sequences S2-S4) reflects global processes. See text for further discussion. A summary of South Island tectonic and volcanic events is also shown. (Figure shown on next page.) 
Figure F11 (continued). (Caption shown on previous page.)

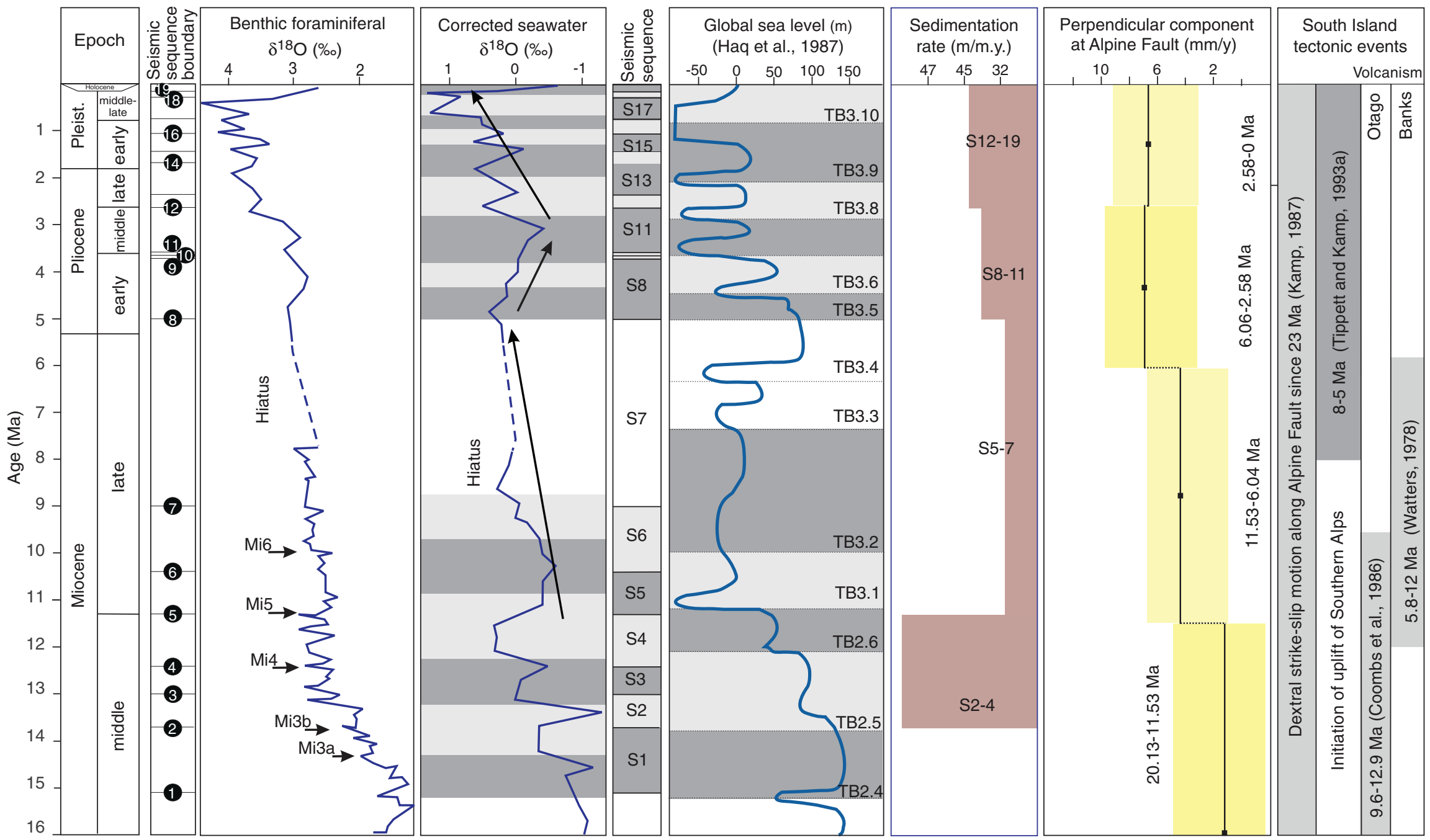


Figure F12. Correlation of seismic sequence boundaries U1-U14 (predrilling age estimates) targeted during Expedition 317 with periods of sediment drift activity and the oxygen isotopic record from Deep Sea Drilling Project (DSDP) Site 588 in the southwest Pacific (Kennett and von der Borch, 1986). The relative size of the ellipse representing each drift is an approximate measure of drift volume. Drifts D1-D4 are of short duration ( 3 m.y.), whereas D10-D11 are larger and longer lived ( 7 m.y.). Dark and light shading represent cool and warm periods, respectively, as defined by Kennett and von der Borch (1986).

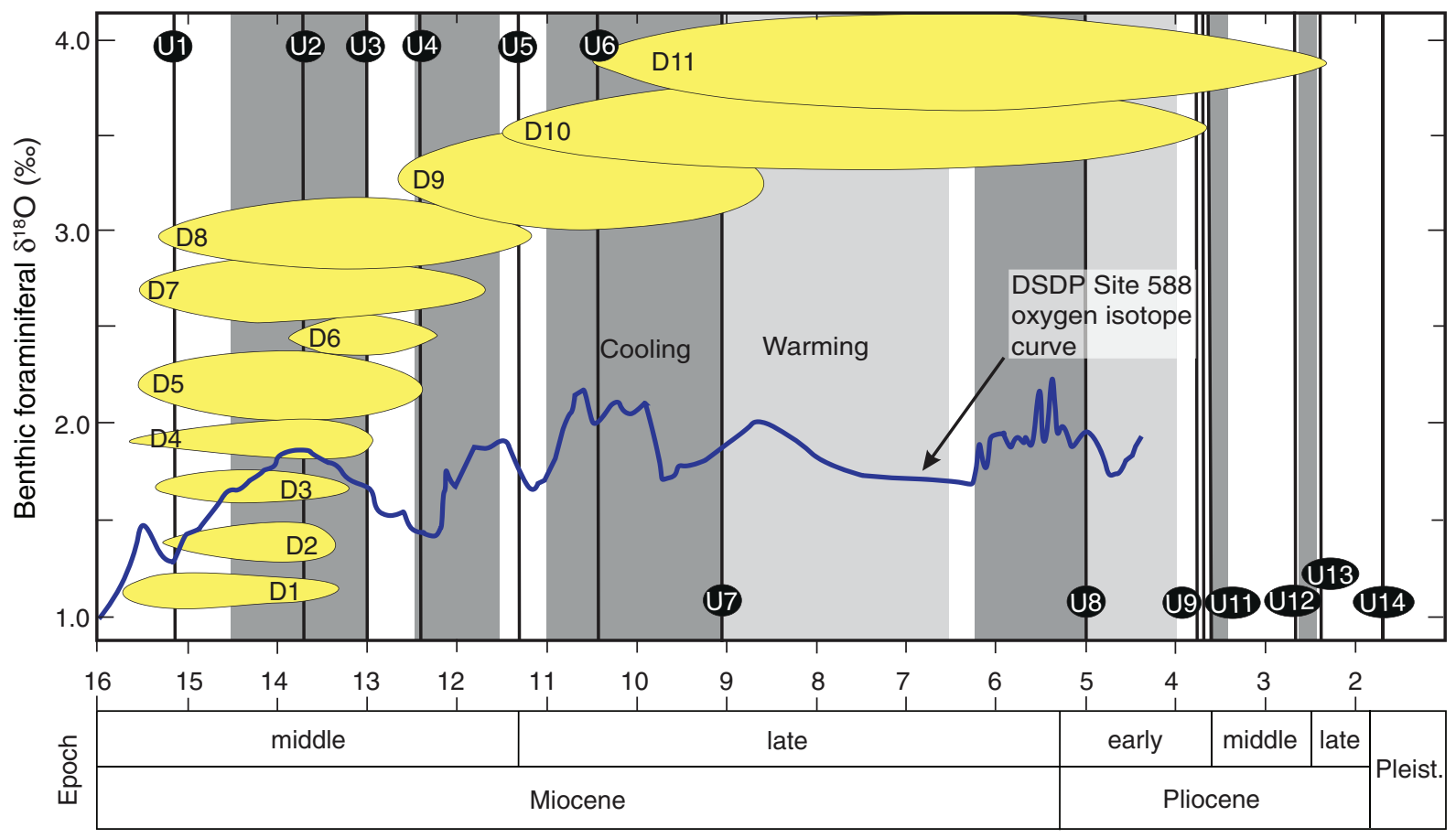

Age (Ma) 
Figure F13. Correlation of lithologic units defined at shelf Sites U1353, U1354, and U1351 to interpreted dip-oriented seismic Profile EW00-0166. Red $=$ actual penetration, yellow $=$ proposed penetration. A. Uninterpreted seismic profile showing site locations (see also Fig. F7). B. Correlation of lithologic Units I and II at shelf Sites U1353, U1354, and U1351, overlain on seismic Line EW00-01-66. The location of the Unit I/II boundary (teal) at Site U1351 is uncertain (see "Lithostratigraphy" in the "Site U1351" chapter). The Unit I/II boundary (teal) at Site U1353 is placed at $151 \mathrm{~m}$; other options are possible (see "Lithostratigraphy" in the Site U1353 chapter). MP = Marshall Paraconformity.

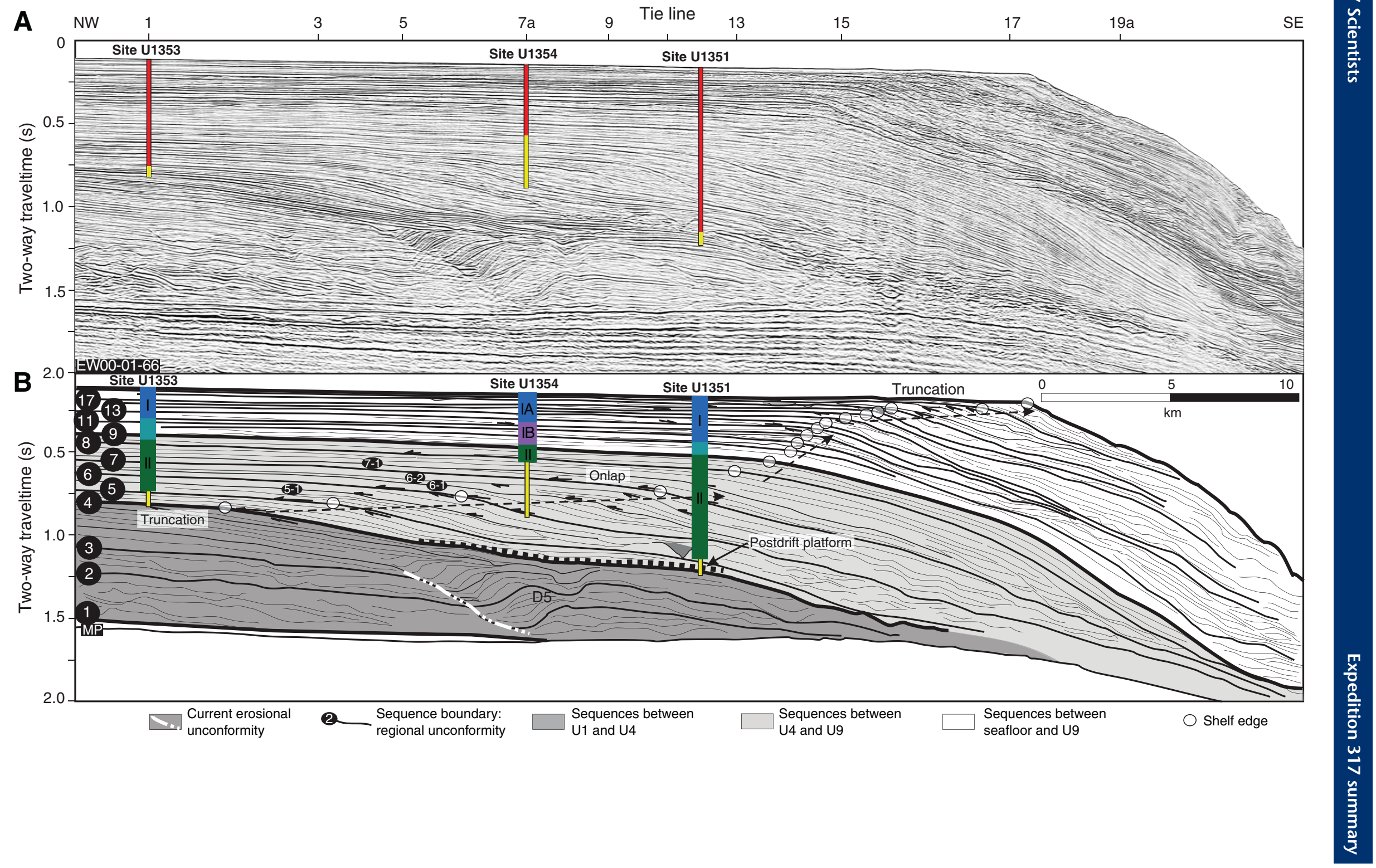


Figure F14. Correlation of lithologic units defined at Site U1352 to dip-oriented seismic Profile EW00-01-60. A. Uninterpreted profile showing site location. B. Interpretation based on predicted depths of seismic reflectors and assumptions about the type of bedding that causes these reflections. MP = Marshall Paraconformity.

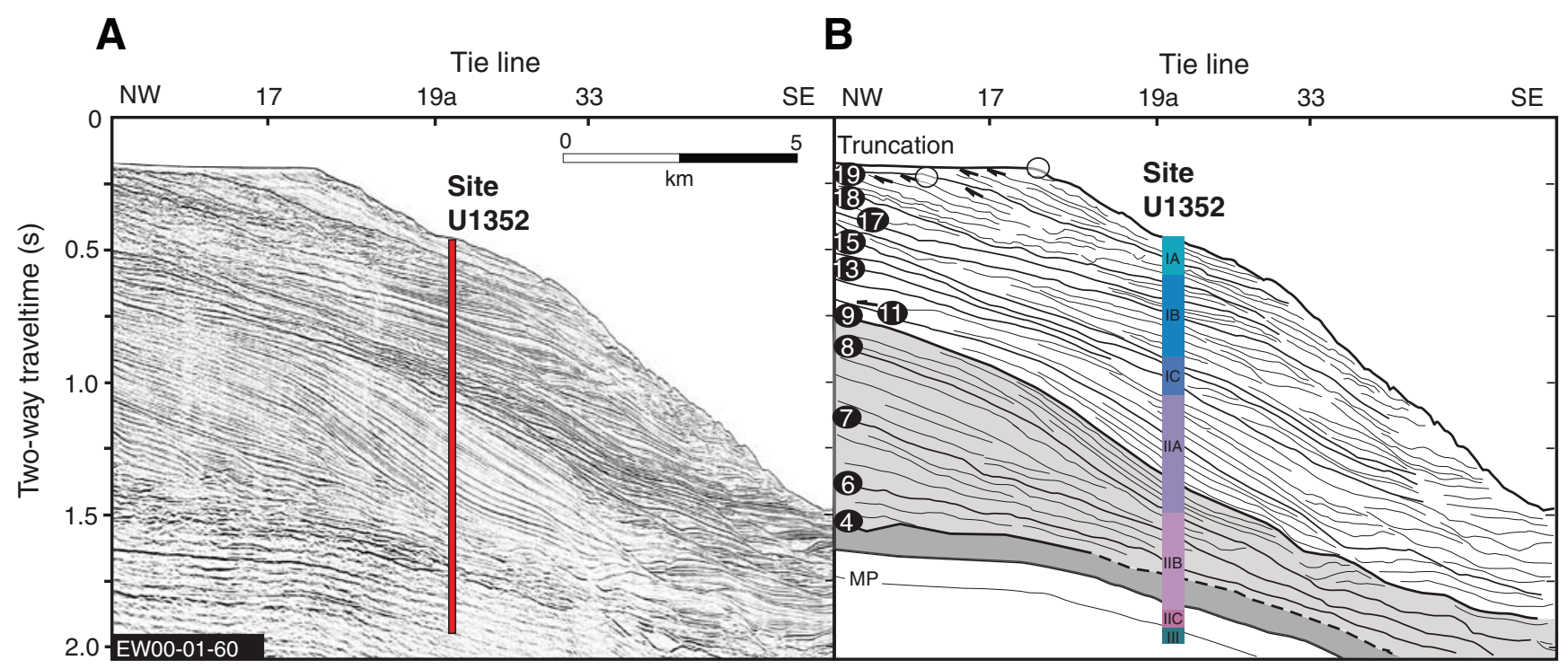


Figure F15. Summary of lithology and unit boundaries, Expedition 317. Seismic sequence boundaries U19-U5 are shown schematically, intersecting each site at their predicted depths. Ages were determined from biostratigraphy. MP = Marshall Paraconformity.

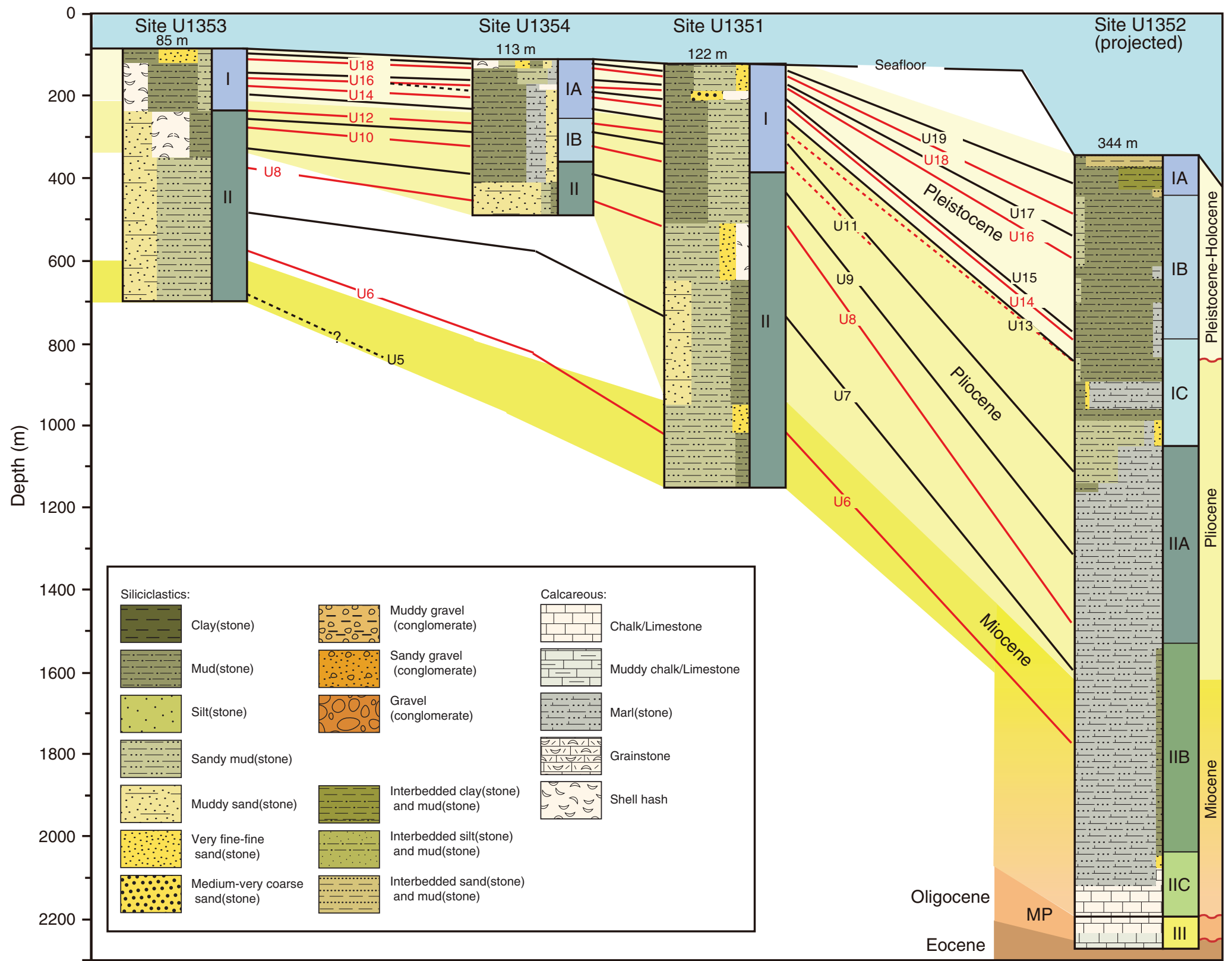


Figure F16. Carbonate component percent estimates from smear slide data (blue circles), plotted with estimates from coulometry analyses (red diamonds) and thin sections (purple crosses), Expedition 317. Seismic sequence boundaries U19-U5 are shown schematically, intersecting each site at their predicted depths. Ages were determined from biostratigraphy. MP = Marshall Paraconformity.

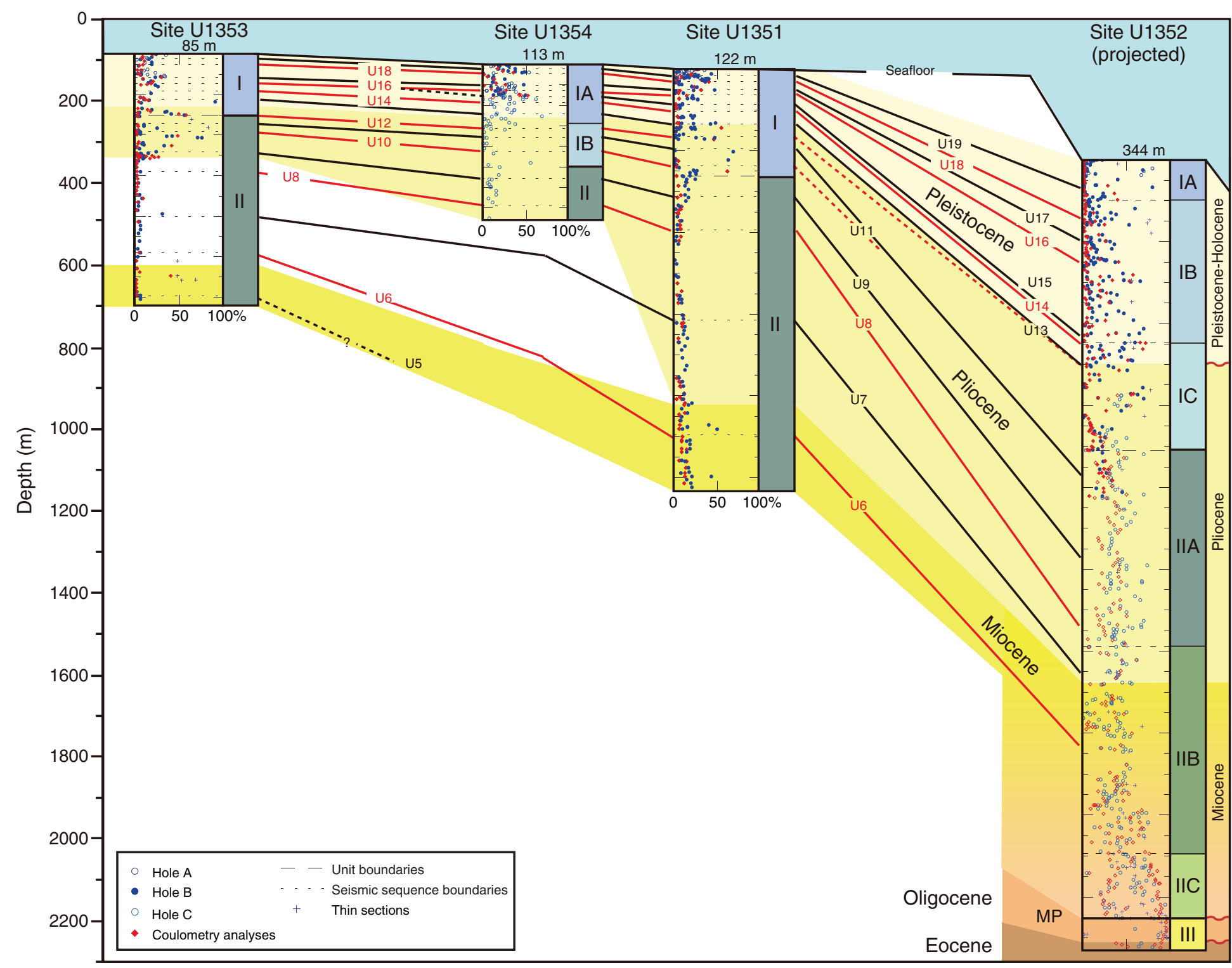


Figure F17. Summary of core recovery across the Expedition 317 transect. Recovery was particularly low in lithologic Unit II at shelf Sites U1353, U1354, and U1351. MP = Marshall Paraconformity.

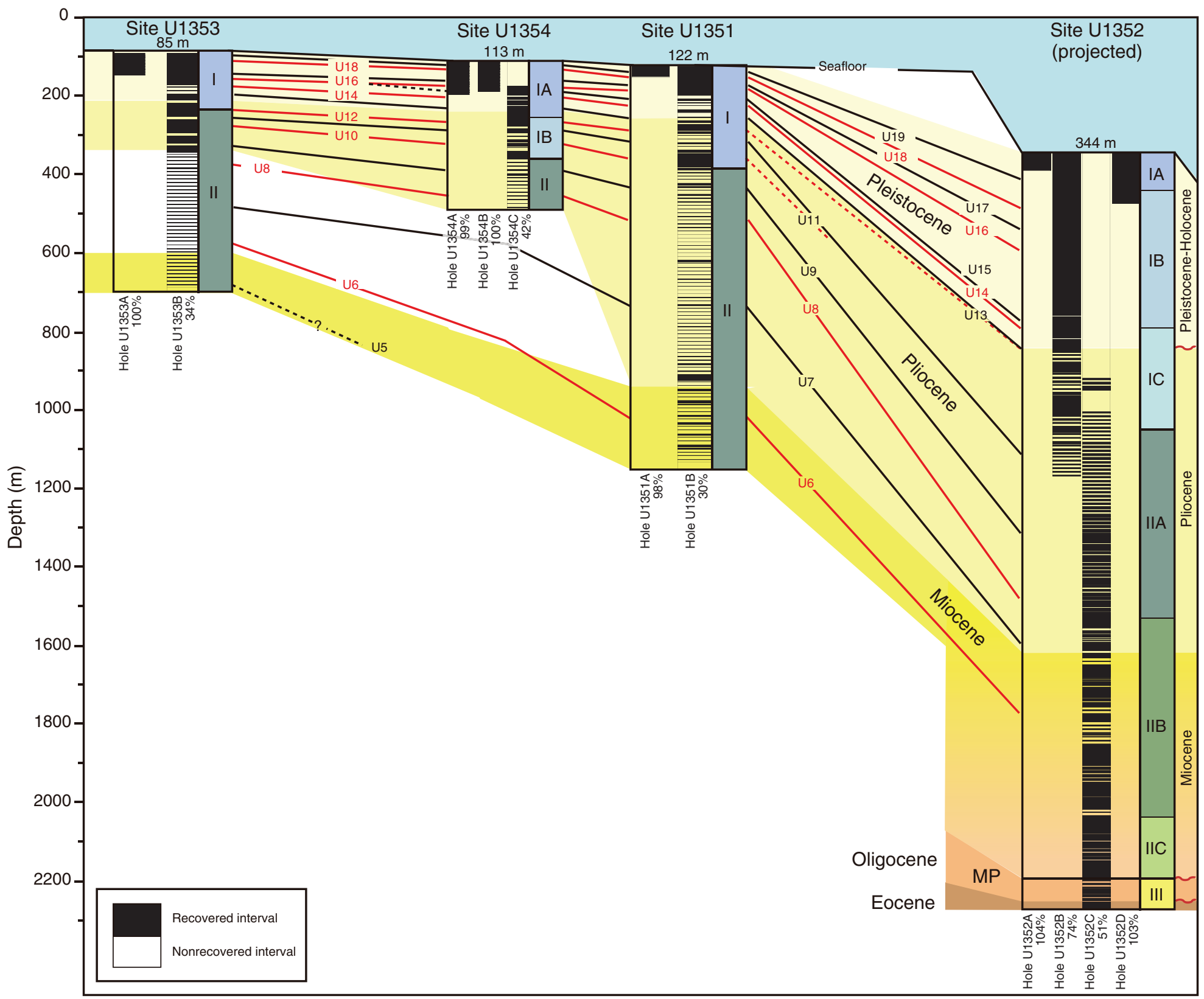


Figure F18. Calcium carbonate content in Hole U1352B and in Ocean Drilling Program (ODP) Hole 1119C. Major lithologic units at both sites correlate with carbonate content and similar depth trends in carbonate content. A distinctly low carbonate (clay-rich) interval at 430 mbsf at Site 1119 corresponds to a similar lowcarbonate interval at $\sim 620$ mbsf at Site U1352.

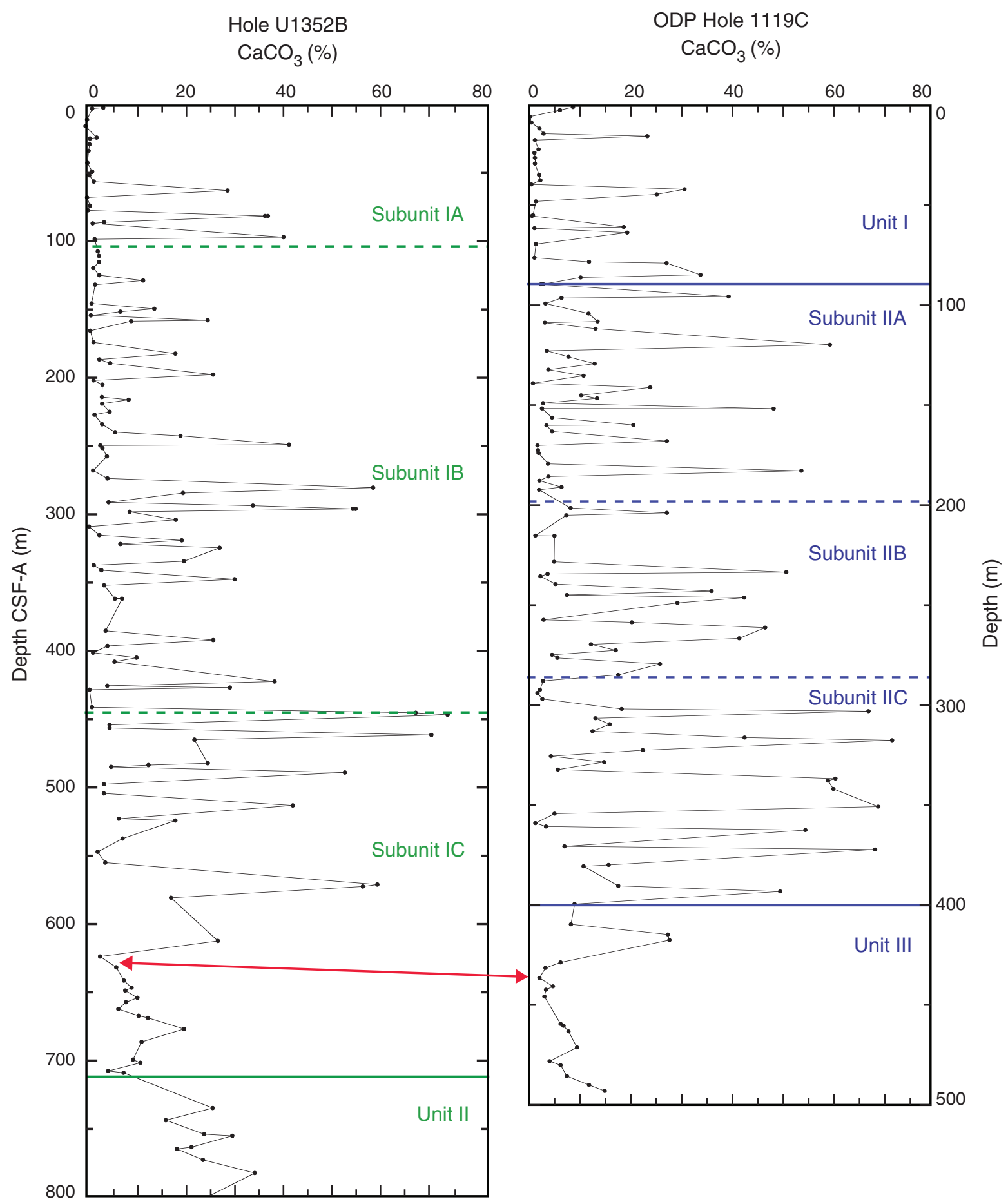


Figure F19. The Expedition 317 drilling transect across the shelf and upper slope of the Canterbury Basin permits correlation of lithology to seismic sequence boundaries. Lithologic contacts and their overlying associated facies were documented, and preliminary correlations were made to the predicted depths of seismic sequence boundaries. At Sites U1352 and U1354, at which recovery was high, there is good correlation between the sedimentary and seismic records, particularly above U10. The figure illustrates the depths of lithologic contacts at each site (e.g., inner shelf, U1351-S1 [99 m]). U19-U5 are shown schematically, intersecting each site at their predicted depths. Future shore-based studies will expand on these initial results. For further details about lithologic surfaces, see Tables T4 in the "Site U1351" chapter, T4 in the "Site U1352" chapter, T2 in the "Site U1353" chapter, and T3 in the "Site U1354" chapter. Black lines = seismic sequence boundaries, red lines $=$ lithologic boundaries. Contacts shown in blue are uncertain because of poor recovery. MP = Marshall Paraconformity. (Figure shown on next page.) 
Figure F19 (continued). (Caption shown on previous page.)

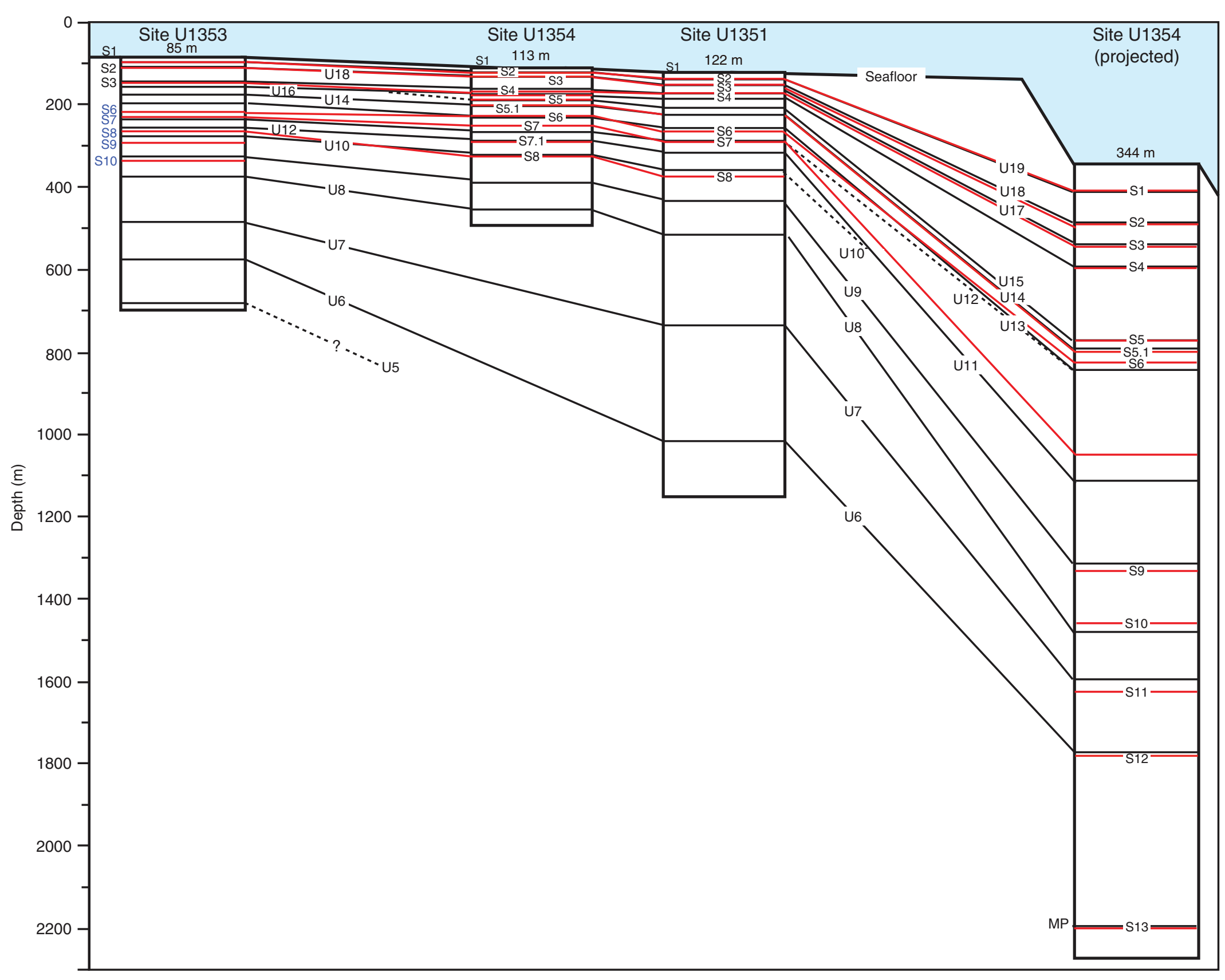


Figure F20. Enlargement of the shelf portion of the Expedition 317 drilling transect showing lithologic contacts and correlative seismic sequence boundaries. Note that contacts shown in blue at Site U1353 are particularly tentative because of poor recovery in that interval.

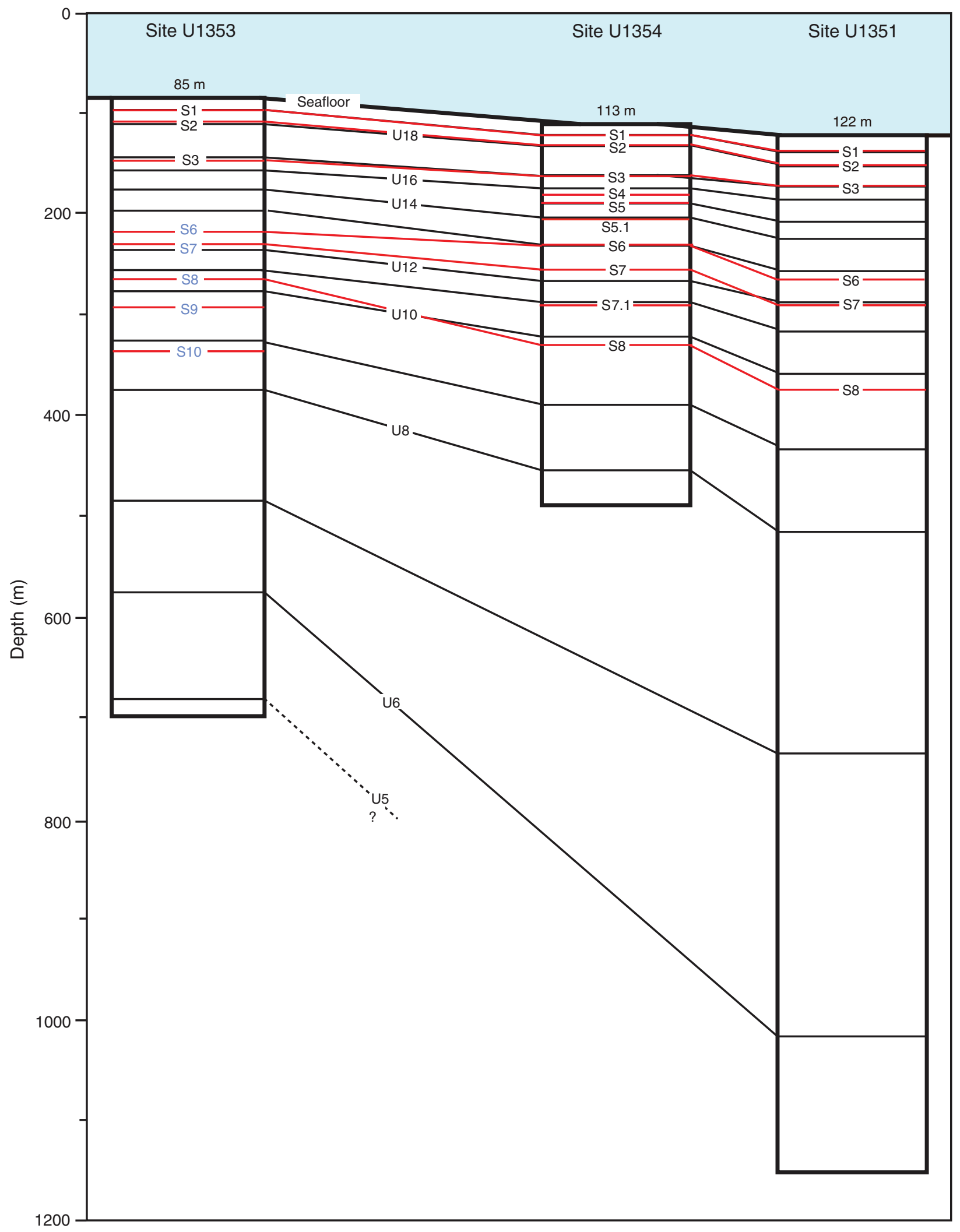


Figure F21. Schematic of possible correlation of the uppermost part of the Holocene-Pleistocene succession between Holes U1351B, U1353B, and U1354B. Columns are aligned relative to top depth and distance (not to scale). Distinct lithologic boundaries and two predominant sand beds can be correlated among the columns. Four depositional units are well defined: an uppermost unit of possible Holocene age and three units of possible upper Pleistocene age. The two thick, well-sorted, very fine-fine sand beds at the most landward site (Hole U1353B) thin offshore. The upper sand bed disappears into a sandy interval in Holes U1354B and U1351B.

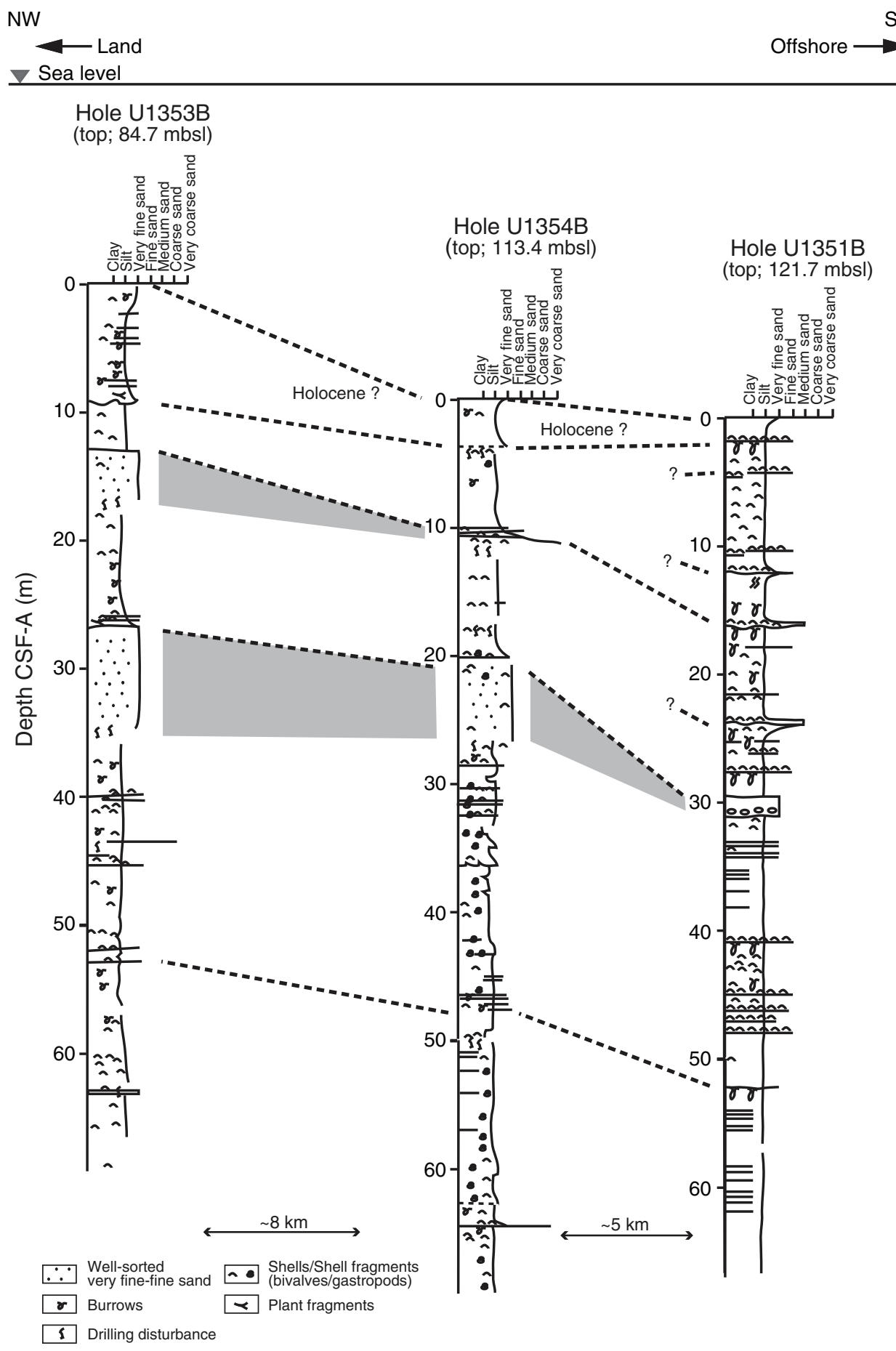


Figure F22. Chronostratigraphic framework and biostratigraphic ages of predicted seismic sequence boundary units across the Expedition 317 drilling transect. Pleistocene ages are derived from calcareous nannofossils. Pliocene-Eocene ages are derived from calcareous nannofossils and planktonic foraminifers (early Pliocene-late Miocene ages are primarily from planktonic foraminifers). Major hiatuses indicated by microfossil biostratigraphy are displayed in the epoch (left-hand) column for each site. Right-hand columns provide ages (in Ma) at the predicted depths of seismic sequence boundaries. U19-U5 are shown schematically, intersecting each site at their predicted depths. The Marshall Paraconformity (MP) is noted for Site U1352 as the unconformable boundary between the early Miocene and early Oligocene. (Figure shown on next page.) 
Figure F22 (continued). (Caption shown on previous page.)

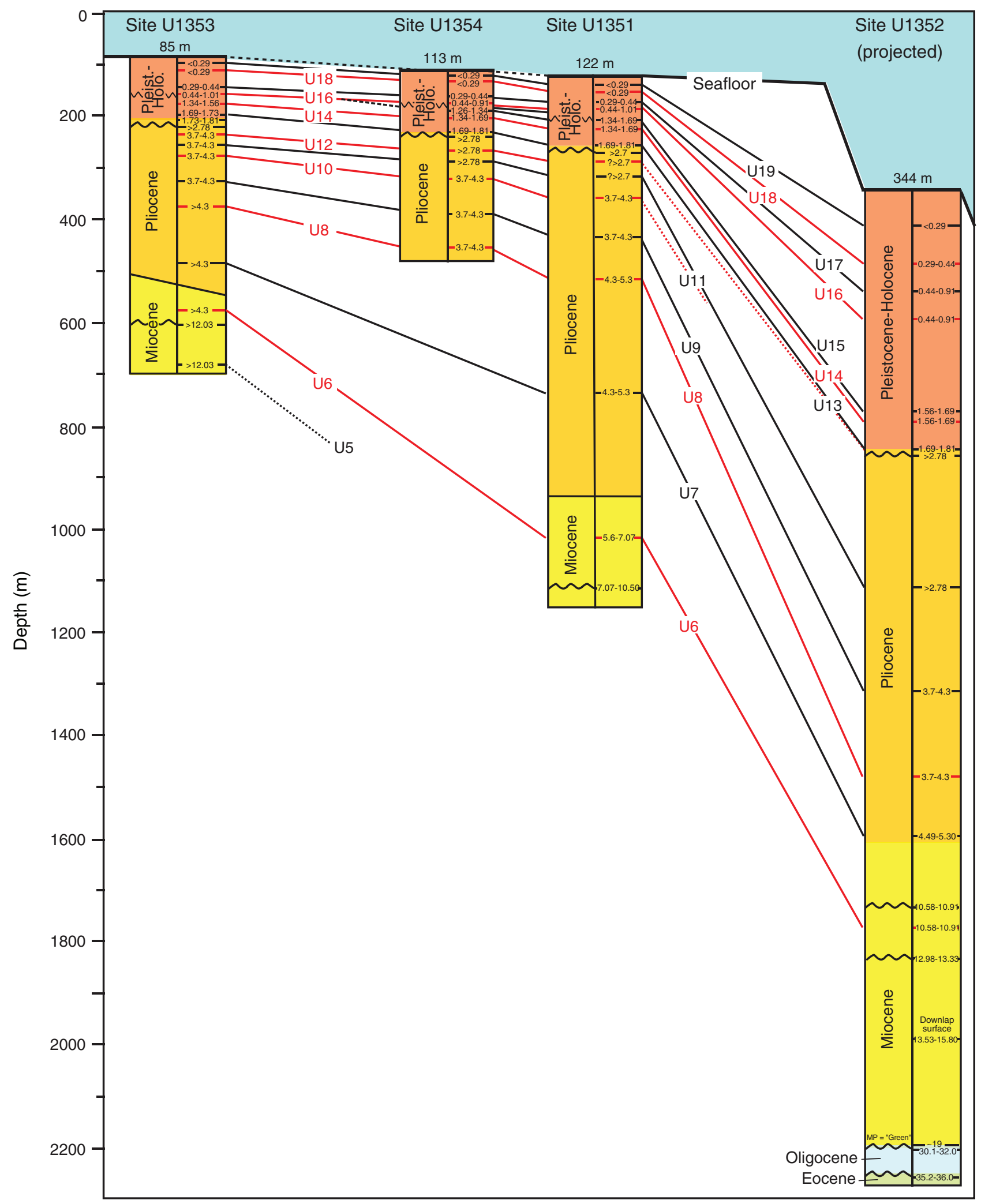


Figure F23. Magnetic susceptibility (left-hand column) was measured on whole-round samples at $2.5 \mathrm{~cm}$ intervals (instrument units [IU]) using a Bartington Instruments MS Loop sensor. NGR (right-hand column) was measured on whole-round samples at $10 \mathrm{~cm}$ intervals (counts per second [cps]) using the Natural Gamma Radiation Logger (NGRL) designed and built at Texas A\&M University by IODP-USIO. To help illustrate key trends, the signal was cleaned using a Gaussian low-pass filter (30 passes). The data correlate well between the two methods and between sites: both data sets show similar cyclic patterns in the uppermost $250 \mathrm{~m}$ at all sites. Some unconformities are well represented by abrupt changes. The Marshall Paraconformity (MP) is characterized at Site U1352 by a switch to negative magnetic susceptibility and a decrease in NGR to nearly zero. (Figure shown on next page.) 
Figure F23 (continued). (Caption shown on previous page.)

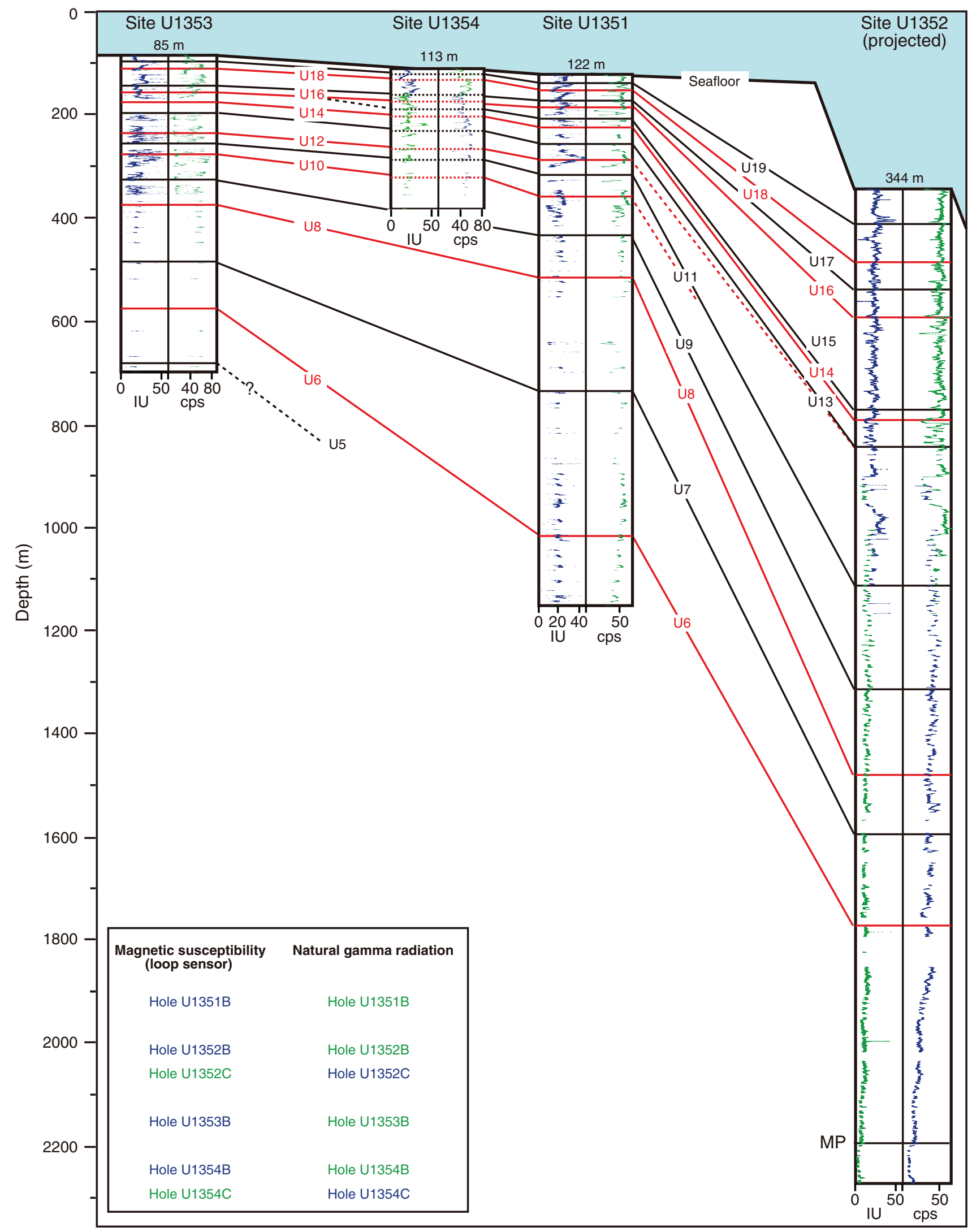


Figure F24. Lithologic columns, color, and magnetic susceptibility (MS) at shelf Sites U1353, U1354, and U1351. The 0-150 m intervals at each site are compared. Red lines = marine isotope stage (MIS) boundaries tentatively correlated with lithologic cycles. Nannofossil ages are shown to the left of each column. IU = instrument units.

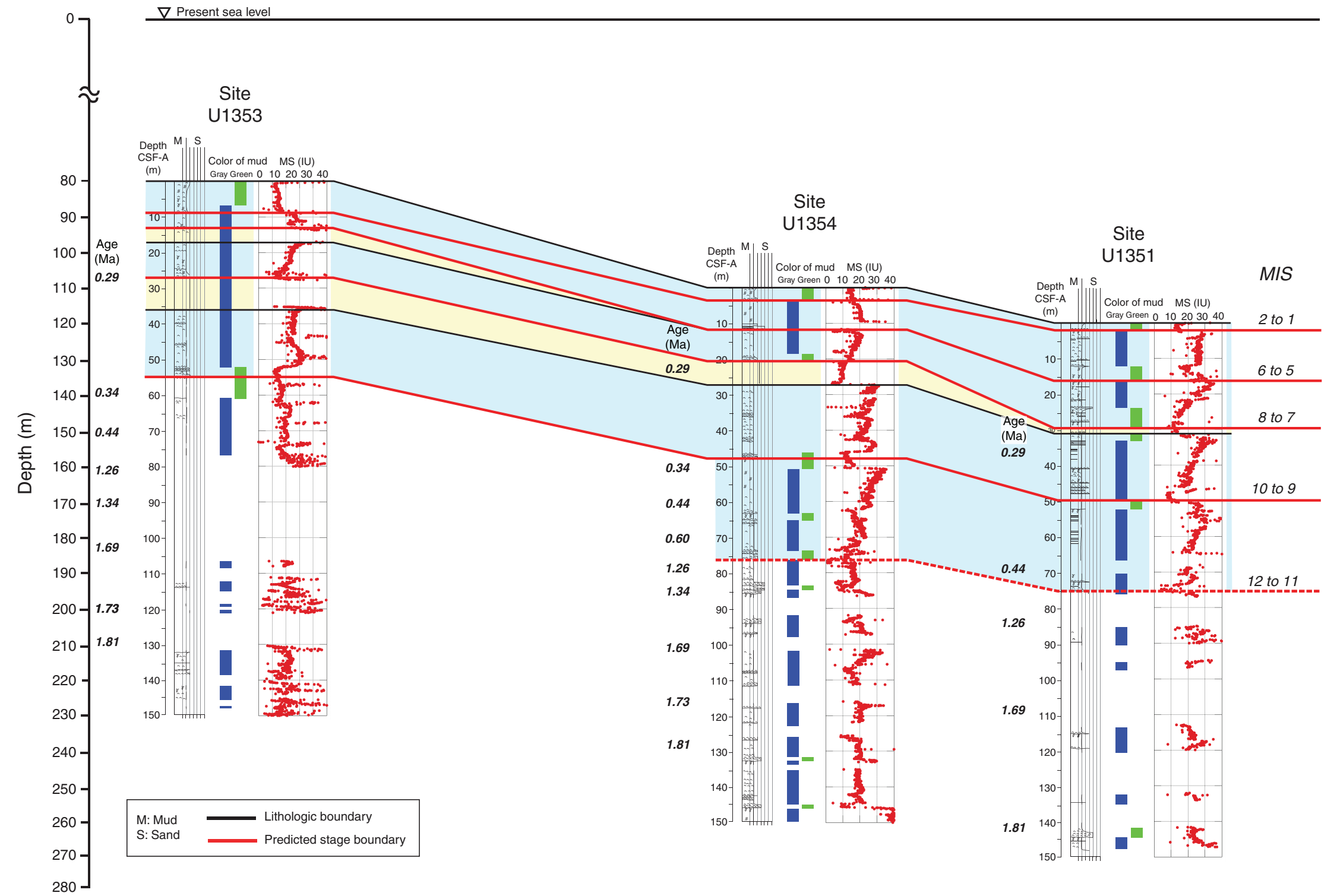


Figure F25. Summary of natural gamma ray and electrical resistivity data from wireline logging of Sites U1353, U1354, U1351, and U1352. Seismic sequence boundaries U10-U12, in particular, are distinct features in the logging data characterized by low gamma radiation and high resistivity and can be well correlated across the three shelf sites. GR = gamma ray, IDPH = phasor deep induction log.

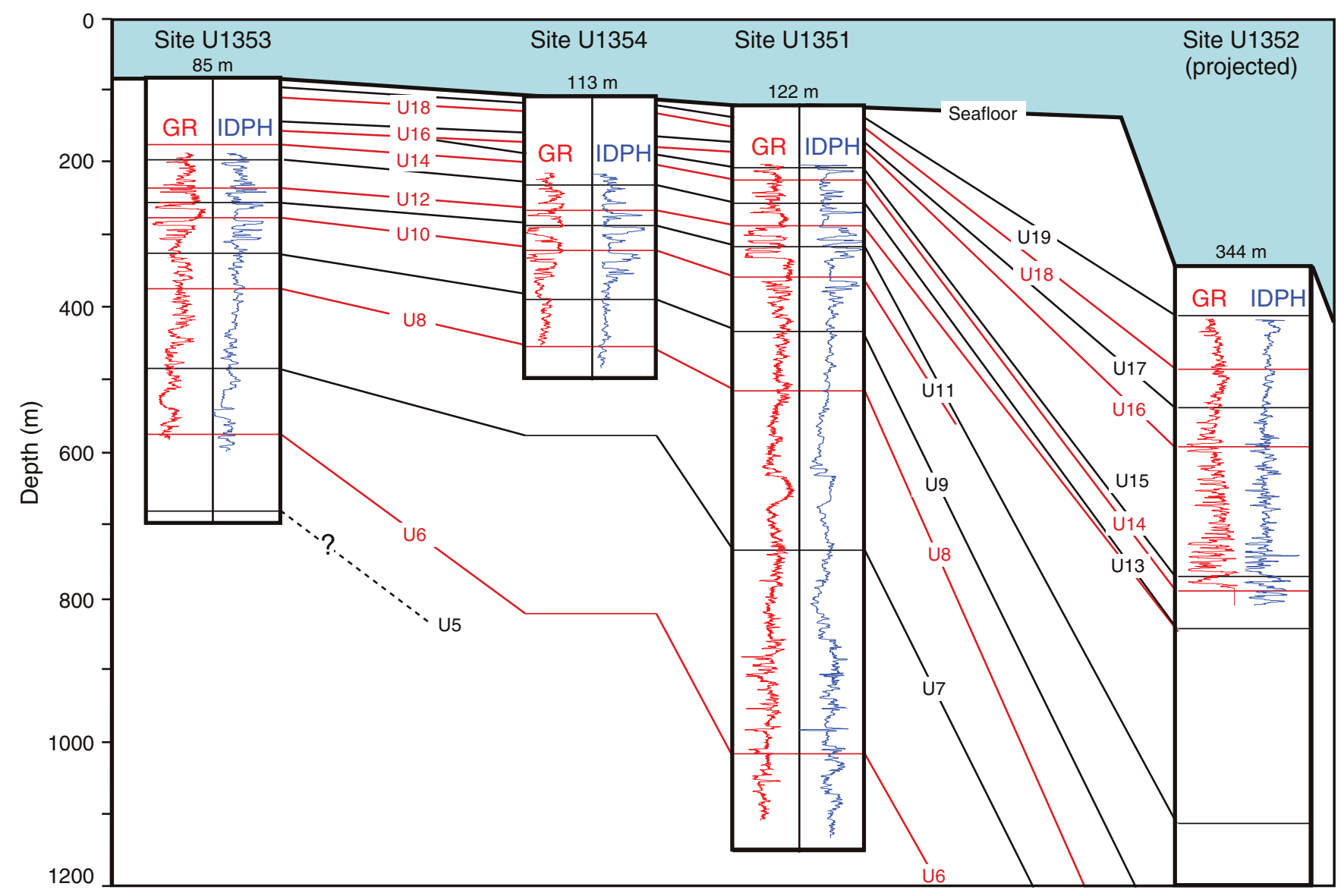


Figure F26. Downhole and across-transect variations in oceanicity. Planktonic foraminiferal abundance (\%) provides a measure of oceanicity and is a relative measure of distance from land.

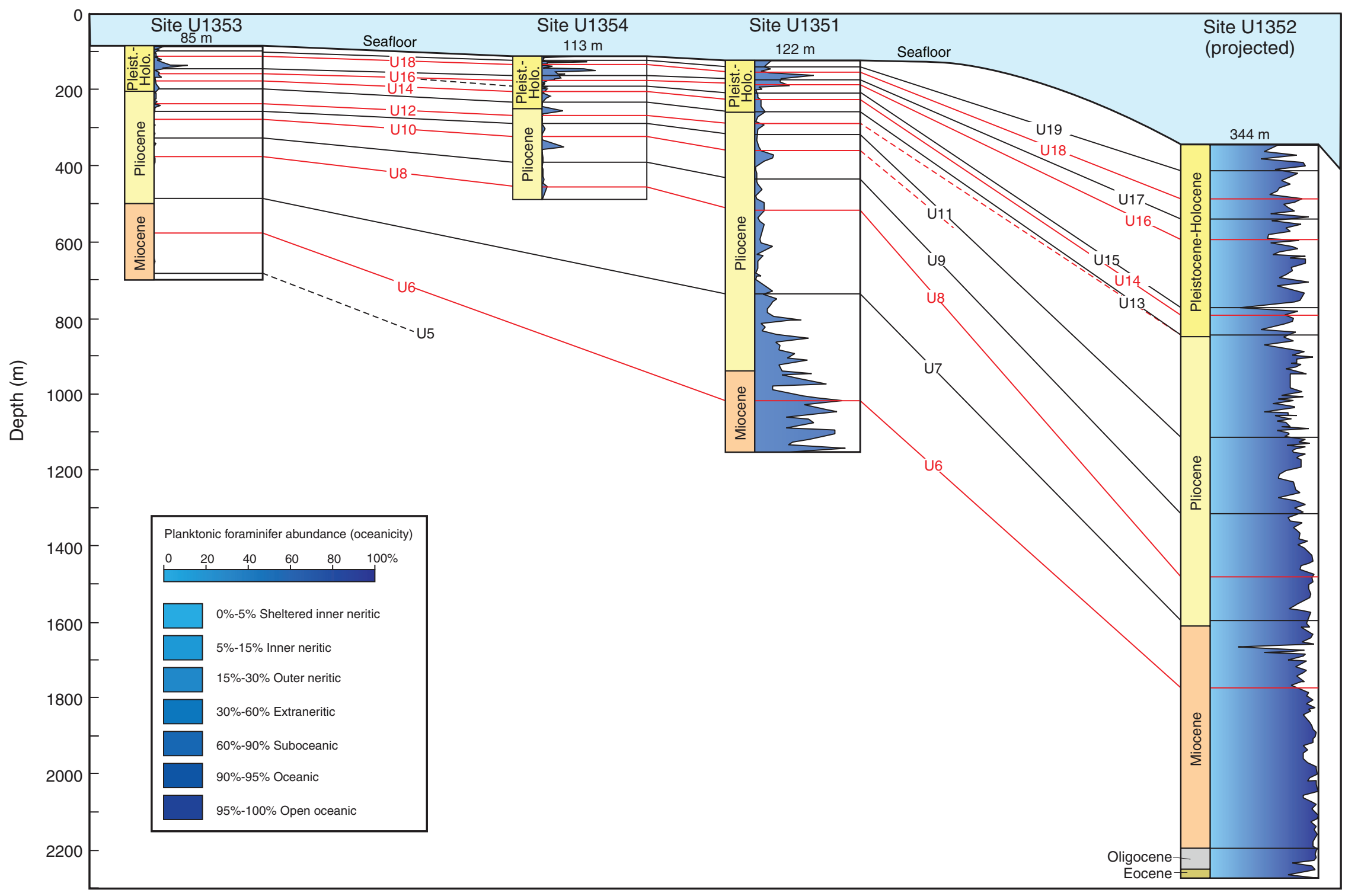


Figure F27. Benthic foraminifer-derived paleowater depth changes across Sites U1353, U1354, U1351, and U1352. Seismic sequence boundaries U19-U5 are shown schematically, intersecting each site at their predicted depths.

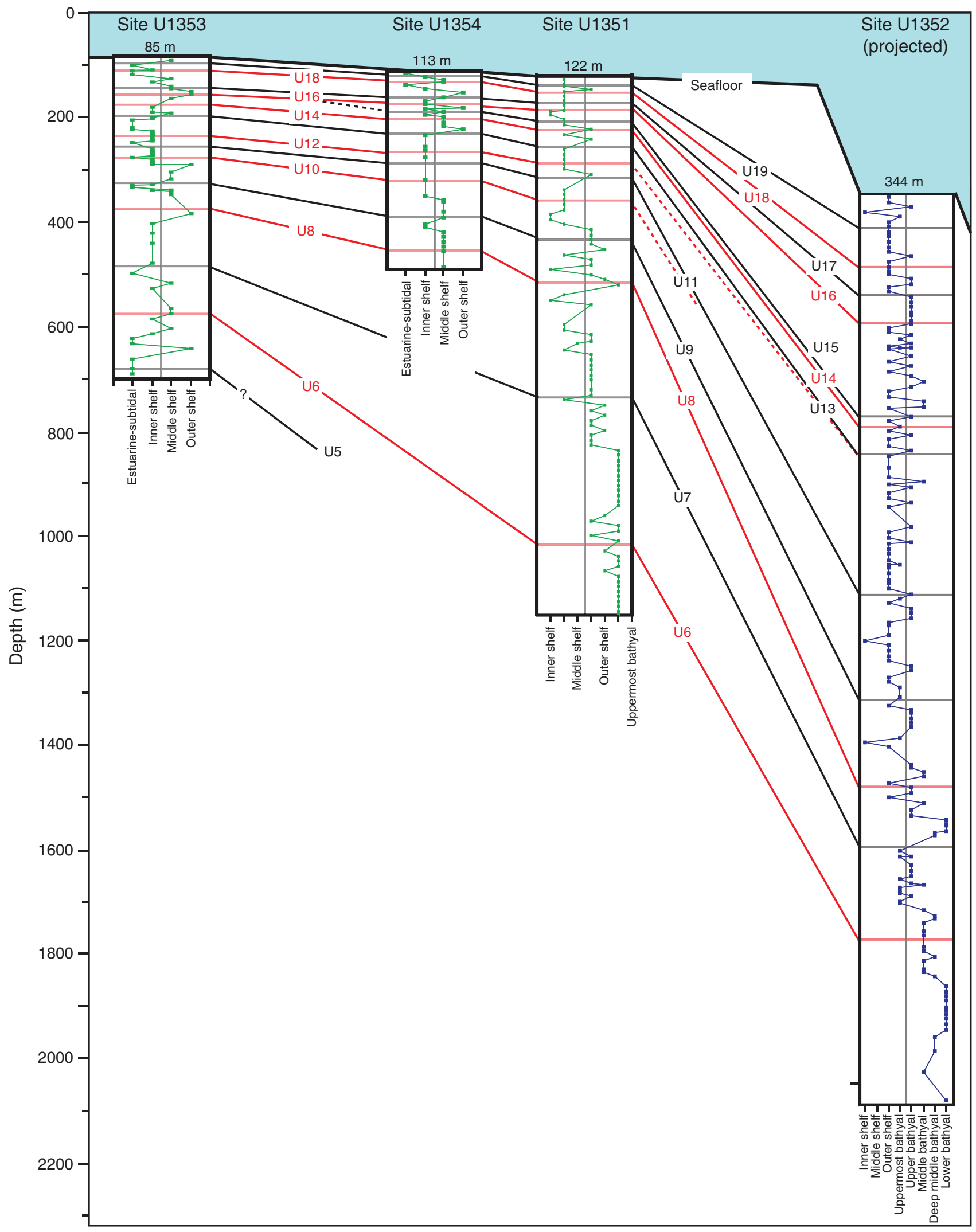


Figure F28. Age-depth plot for Hole U1353B. Sedimentation rates are tentative and based on visual correlation of data. Hiatuses are inferred from biostratigraphic analysis. NZ = New Zealand.

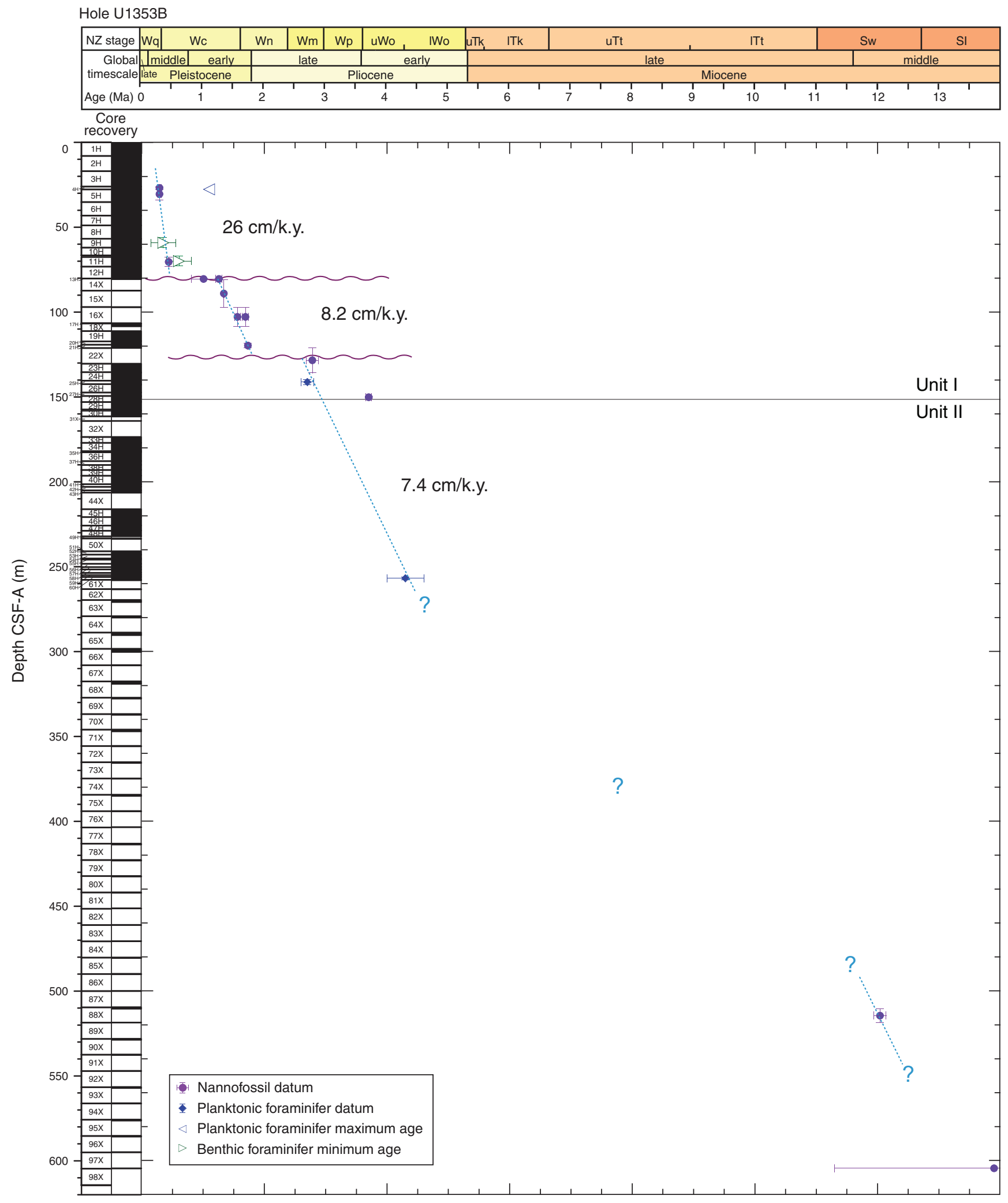


Figure F29. Age-depth plot for Holes U1354A-U1354C. Sedimentation rates are tentative and based on visual correlation of data. Hiatuses are inferred from biostratigraphic analysis. NZ = New Zealand.

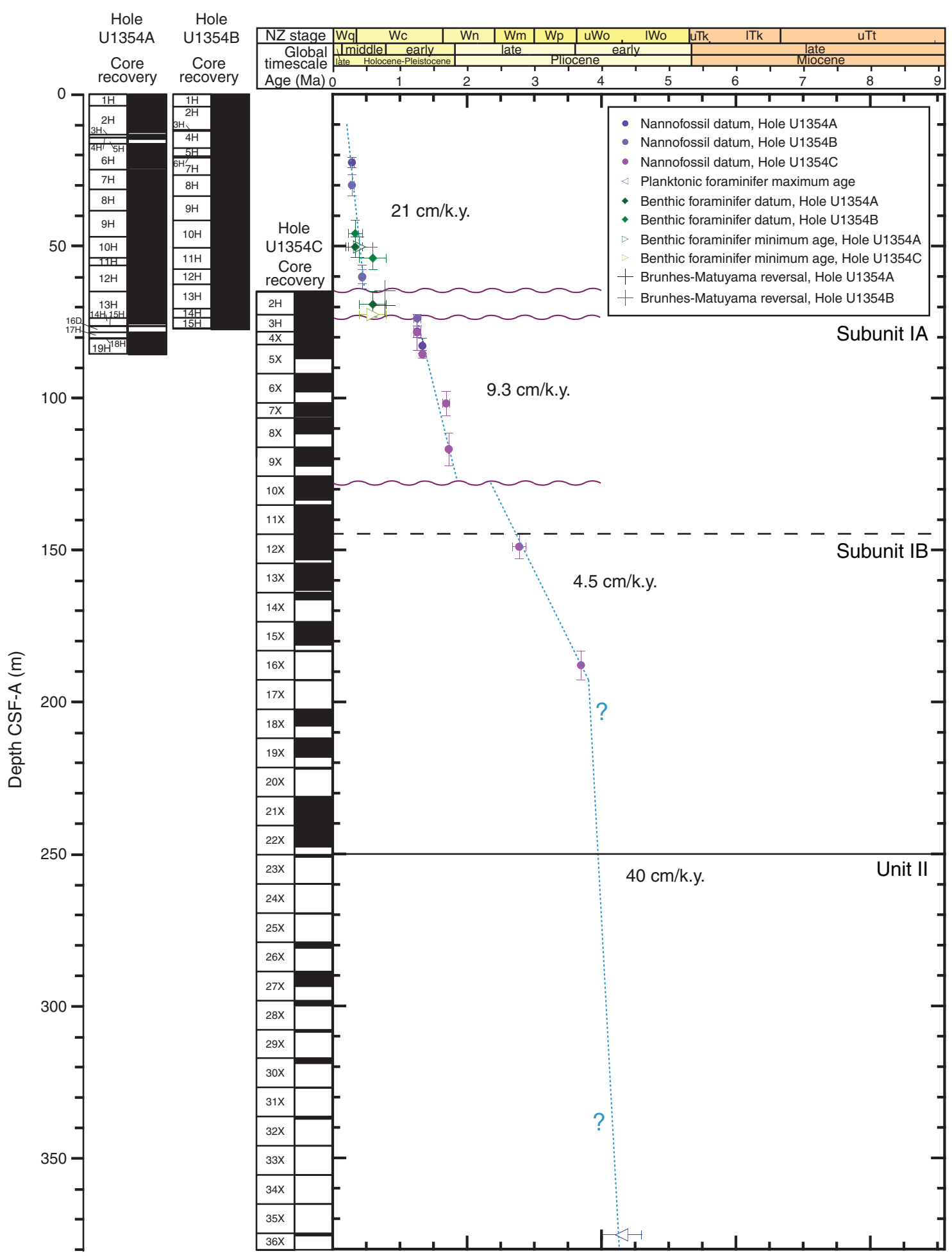


Figure F30. Age-depth plot for Hole U1351B. Sedimentation rates are tentative and based on visual correlation of data. Hiatuses are inferred from biostratigraphic analysis. Hiatus positions are sometimes located at distinct boundaries found in recovered cores, but some hiatuses exist in intervals of low recovery. Dashed wavy lines = the most poorly constrained hiatuses. NZ = New Zealand.

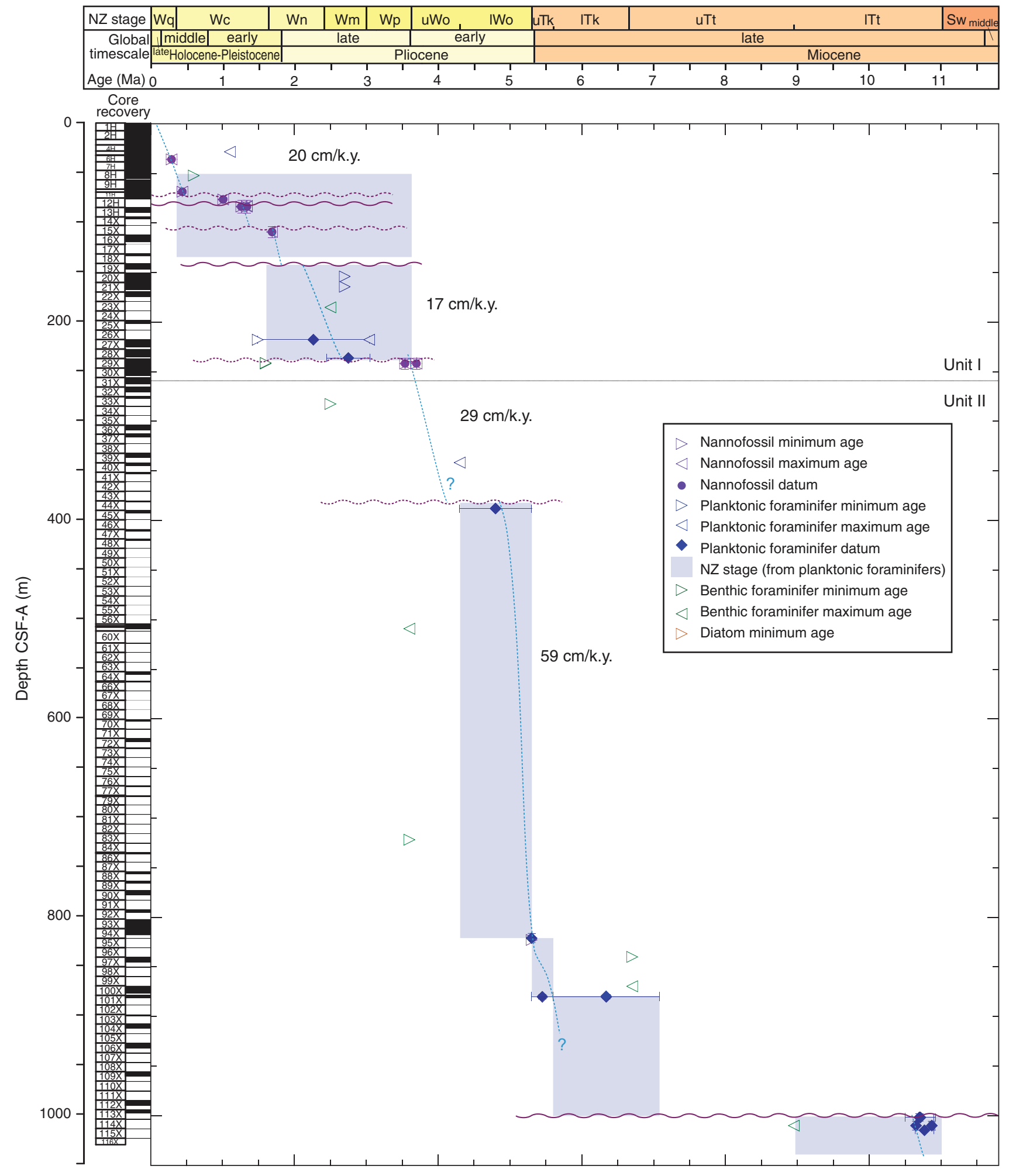


Figure F31. Age-depth plot for Holes U1352B and U1352C. Sedimentation rates are tentative and based on visual correlation of data. Hiatuses are inferred from biostratigraphic analysis. NZ $=$ New Zealand.

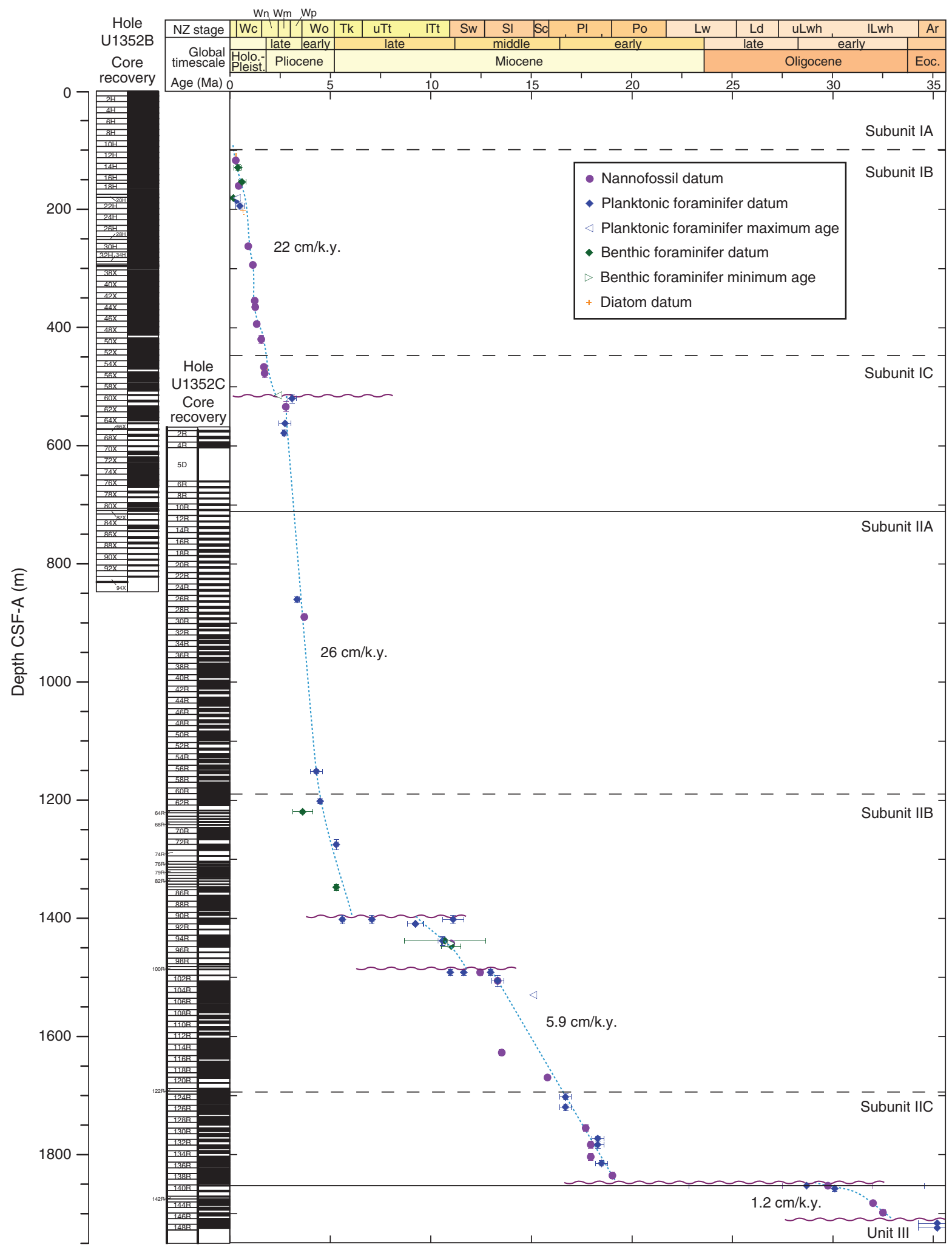


Figure F32. Porosity vs. depth curves, Expedition 317. Seismic sequence boundaries U19-U5 are shown schematically, intersecting each site at their predicted depths. MP = Marshall Paraconformity.

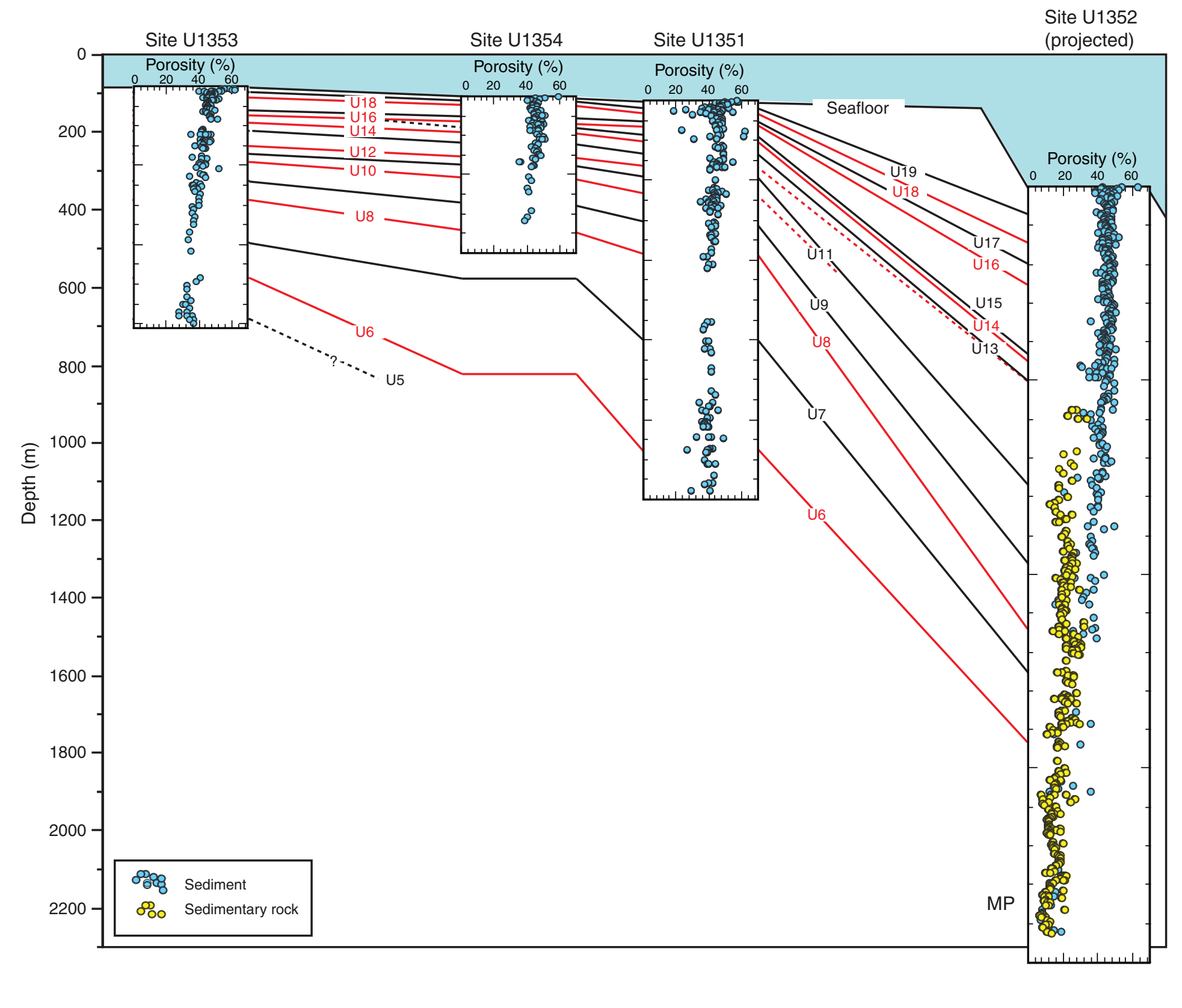


Figure F33. Variation of (A) methane, (B) alkalinity, (C) sulfate, and (D) phosphate concentrations over the uppermost $250 \mathrm{~m}$, Expedition 317.

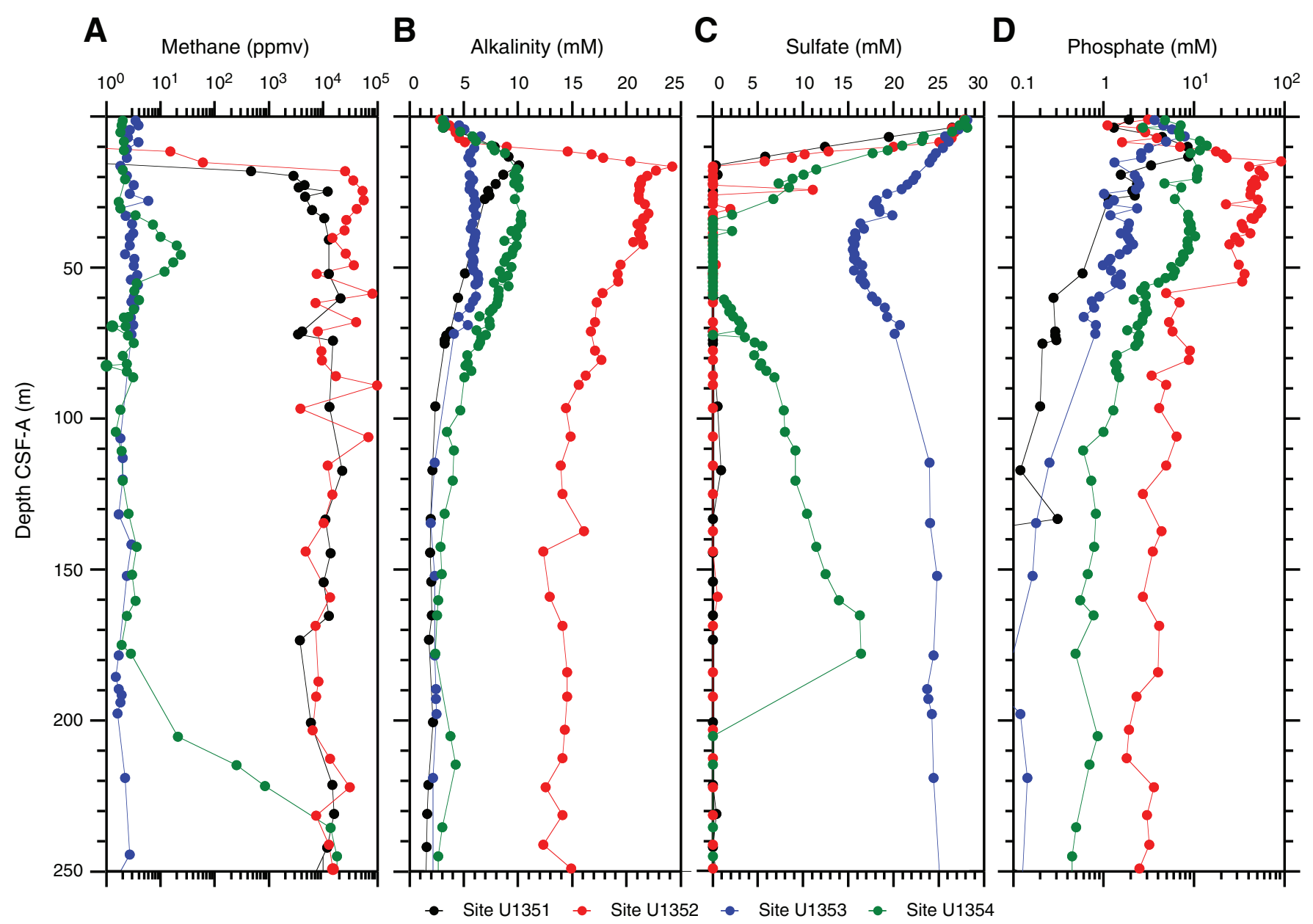




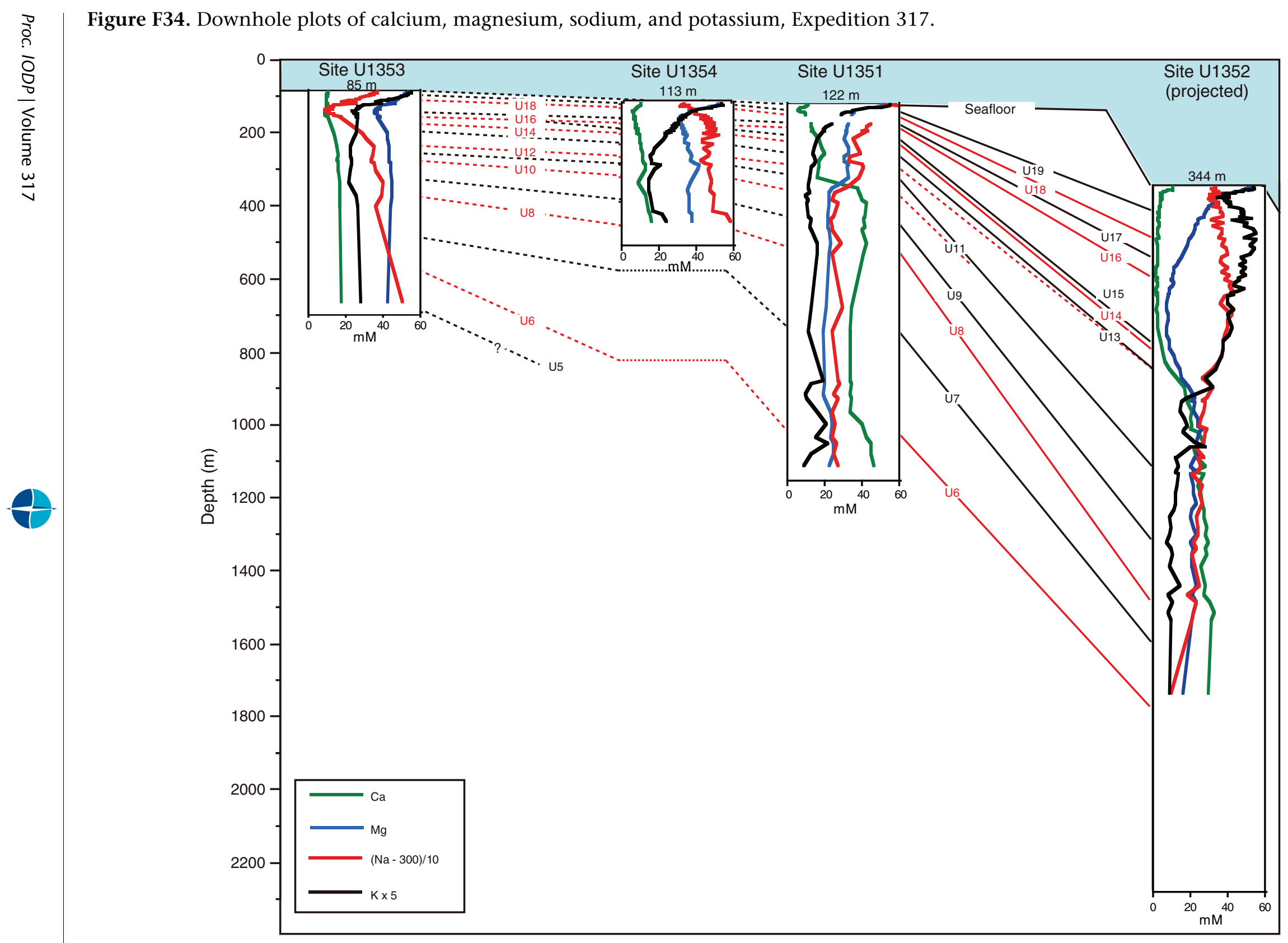


Figure F35. Downhole plots of (A) carbonate, (B) total organic carbon by difference between total carbon from the elemental analyzer and coulometer-derived inorganic carbon $\left(\mathrm{TOC}_{\mathrm{DIFF}}\right),(\mathrm{C})$ ratio of $\mathrm{TOC}_{\mathrm{DIFF}}$ to total nitrogen content, (D) $T_{\max }$, (E) hydrogen index (HI), and (F) production index (PI), Expedition 317.

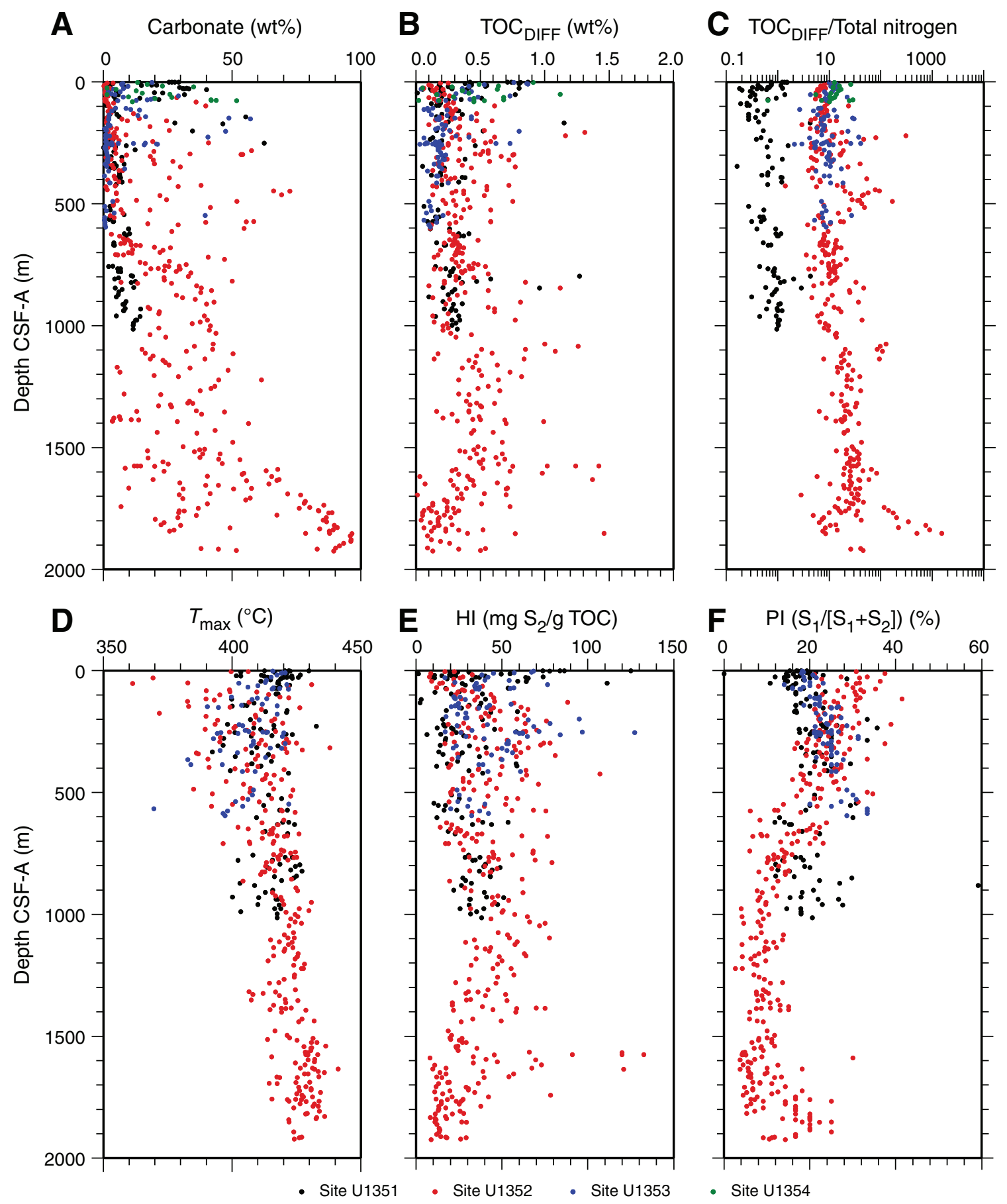


Table T1. Coring summary, Expedition 317. (See table note.)

\begin{tabular}{|c|c|c|c|c|c|c|c|c|c|c|c|}
\hline Hole & Latitude & Longitude & $\begin{array}{l}\text { Water } \\
\text { depth } \\
(\mathrm{m})\end{array}$ & $\begin{array}{l}\text { Cores } \\
(N)\end{array}$ & $\begin{array}{l}\text { Interval } \\
\text { cored } \\
(\mathrm{m})\end{array}$ & $\begin{array}{l}\text { Core } \\
\text { recovered } \\
(\mathrm{m})\end{array}$ & $\begin{array}{l}\text { Recovery } \\
\text { (\%) }\end{array}$ & $\begin{array}{c}\text { Drilled } \\
\text { interval } \\
(\mathrm{m})\end{array}$ & $\begin{array}{l}\text { Total } \\
\text { penetration } \\
(\mathrm{m})\end{array}$ & $\begin{array}{l}\text { Time } \\
\text { on hole } \\
\text { (h) }\end{array}$ & $\begin{array}{l}\text { Time } \\
\text { on site } \\
\text { (days) }\end{array}$ \\
\hline U1351A & $44^{\circ} 53.0307^{\prime} \mathrm{S}$ & $171^{\circ} 50.4037^{\prime} \mathrm{E}$ & 122.3 & 6 & 28.0 & 27.3 & 98 & 0.0 & 28.0 & 14.0 & \\
\hline U1351B & $44^{\circ} 53.0422^{\prime} \mathrm{S}$ & $171^{\circ} 50.4065^{\prime} \mathrm{E}$ & 121.7 & 116 & 1030.6 & 304.5 & 30 & 0.0 & 1030.6 & 162.5 & \\
\hline \multirow[t]{2}{*}{ U1351C } & $44^{\circ} 53.0572^{\prime} \mathrm{S}$ & $171^{\circ} 50.4057^{\prime} \mathrm{E}$ & 121.7 & NA & 0.0 & NA & NA & 967.3 & 967.3 & 104.0 & \\
\hline & & \multicolumn{2}{|c|}{ Site U1351 totals: } & 122 & 1058.6 & 331.8 & 64 & 967.3 & 2025.9 & 280.5 & 11.7 \\
\hline U1352A & $44^{\circ} 56.2440^{\prime} S$ & $172^{\circ} 1.3615^{\prime} \mathrm{E}$ & 343.8 & 5 & 42.2 & 43.9 & 104 & 0.0 & 42.2 & 3.8 & \\
\hline U1352B & $44^{\circ} 56.2558^{\prime} \mathrm{S}$ & $172^{\circ} 1.3630^{\prime} \mathrm{E}$ & 343.6 & 94 & 830.9 & 613.9 & 74 & 0.0 & 830.9 & 120.8 & \\
\hline U1352C & $44^{\circ} 56.2662^{\prime} \mathrm{S}$ & $172^{\circ} 1.3630^{\prime} \mathrm{E}$ & 343.5 & 148 & 1296.4 & 655.0 & 51 & 631.1 & 1927.5 & 361.8 & \\
\hline \multirow[t]{2}{*}{ U1352D } & $44^{\circ} 56.2326^{\prime} \mathrm{S}$ & $172^{\circ} 1.3611^{\prime} \mathrm{E}$ & 344.2 & 14 & 127.0 & 130.8 & 103 & 0.0 & 127.0 & 23.0 & \\
\hline & & \multicolumn{2}{|c|}{ Site U1352 totals: } & 261 & 2296.5 & 1443.6 & 83 & 631.1 & 2927.6 & 509.3 & 21.2 \\
\hline U1353A & $44^{\circ} 46.1079^{\prime} \mathrm{S}$ & $171^{\circ} 40.4368^{\prime} \mathrm{E}$ & 84.2 & 8 & 56.0 & 56.4 & 101 & 0.0 & 56.0 & 12.0 & \\
\hline U1353B & $44^{\circ} 46.1203^{\prime} \mathrm{S}$ & $171^{\circ} 40.4407^{\prime} \mathrm{E}$ & 84.7 & 98 & 614.3 & 211.5 & 34 & 0.0 & 614.3 & 105.5 & \\
\hline \multirow[t]{2}{*}{ U1353C } & $44^{\circ} 46.0982^{\prime} \mathrm{S}$ & $171^{\circ} 40.4380^{\prime} \mathrm{E}$ & 84.7 & NA & 0.0 & NA & NA & 529.0 & 529.0 & 48.3 & \\
\hline & & \multicolumn{2}{|c|}{ Site U1353 totals: } & 106 & 670.3 & 267.9 & 68 & 529.0 & 1199.3 & 165.8 & 6.9 \\
\hline U1354A & $44^{\circ} 50.8281^{\prime} \mathrm{S}$ & $171^{\circ} 47.2096^{\prime} \mathrm{E}$ & 109.8 & 19 & 85.4 & 84.4 & 101 & 0.0 & 85.4 & 23.3 & \\
\hline U1354B & $44^{\circ} 50.8367^{\prime} \mathrm{S}$ & $171^{\circ} 47.2069^{\prime} \mathrm{E}$ & 113.4 & 15 & 77.2 & 77.5 & 100 & 0.0 & 77.2 & 13.8 & \\
\hline \multirow[t]{3}{*}{ U1354C } & $44^{\circ} 50.8487^{\prime} \mathrm{S}$ & $171^{\circ} 47.2080^{\prime} \mathrm{E}$ & 113.4 & 36 & 319.2 & 133.4 & 42 & 65.0 & 384.2 & 53.8 & \\
\hline & & \multicolumn{2}{|c|}{ Site U1354 totals: } & 70 & 481.8 & 295.3 & 81 & 65.0 & 546.8 & 90.8 & 3.8 \\
\hline & & \multicolumn{2}{|c|}{ Expedition 317 totals: } & 559 & 6003.5 & 2338.6 & 74 & 696.1 & 6699.6 & 1046.3 & 43.6 \\
\hline
\end{tabular}

Note: NA = not applicable. 


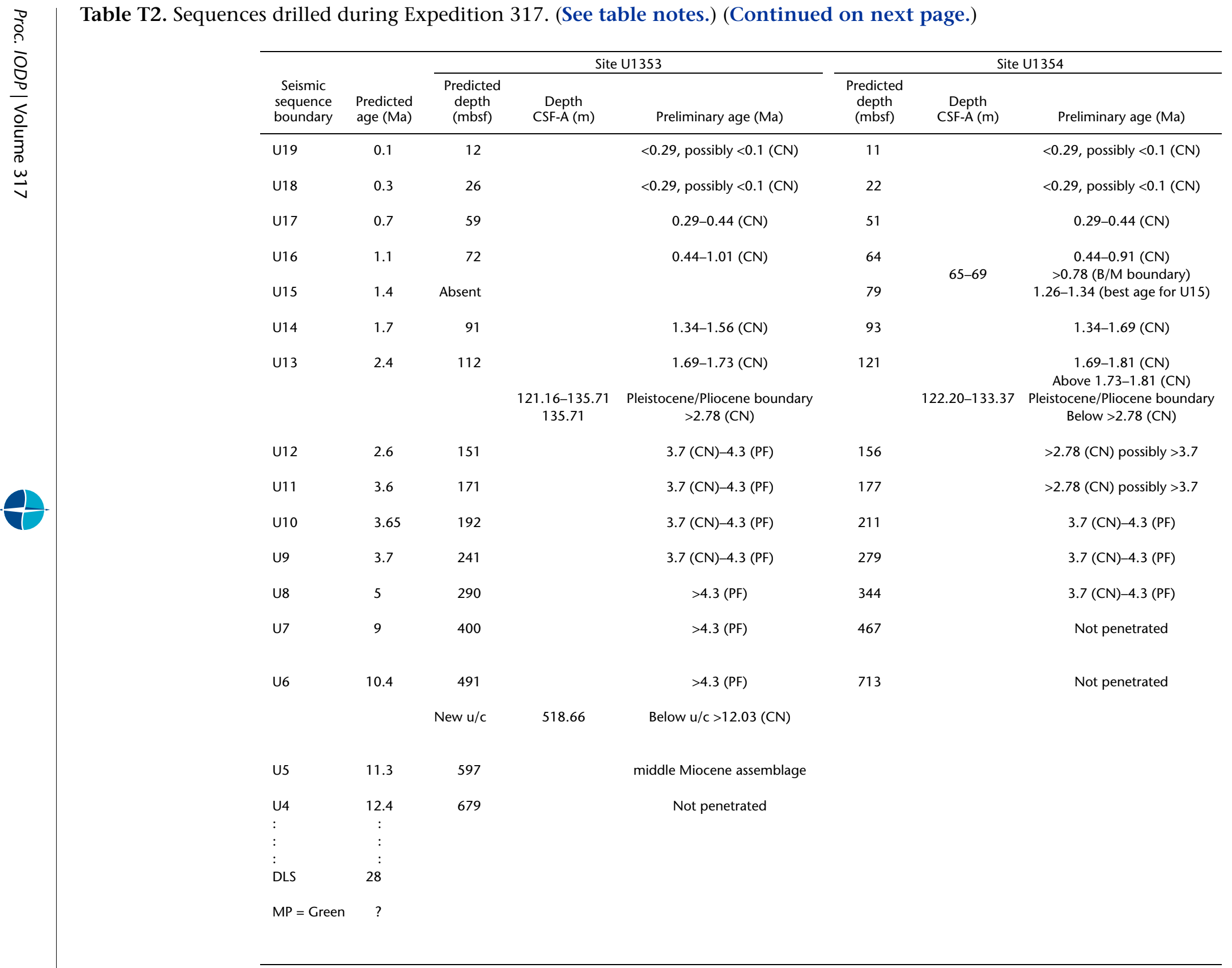




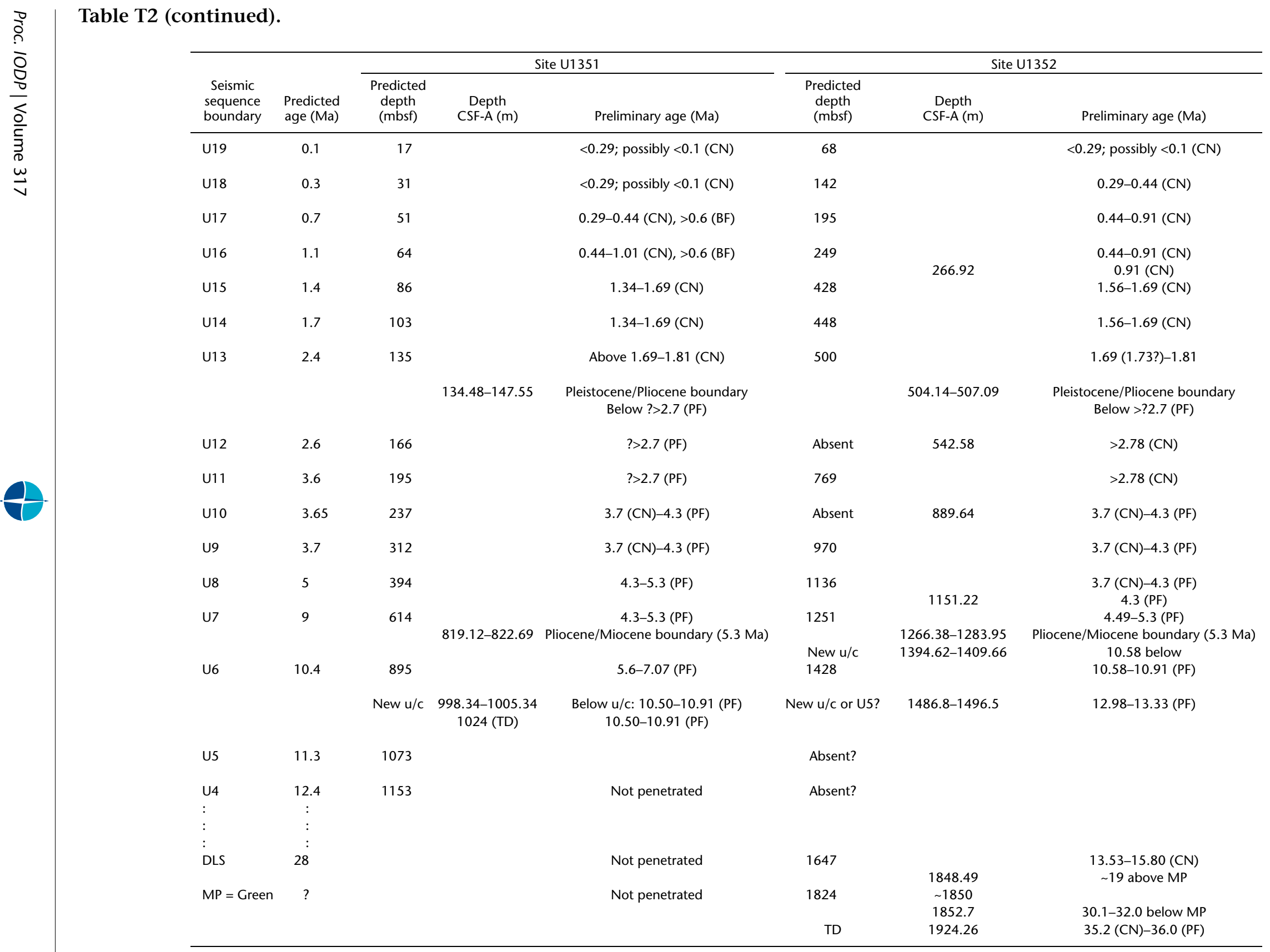

